
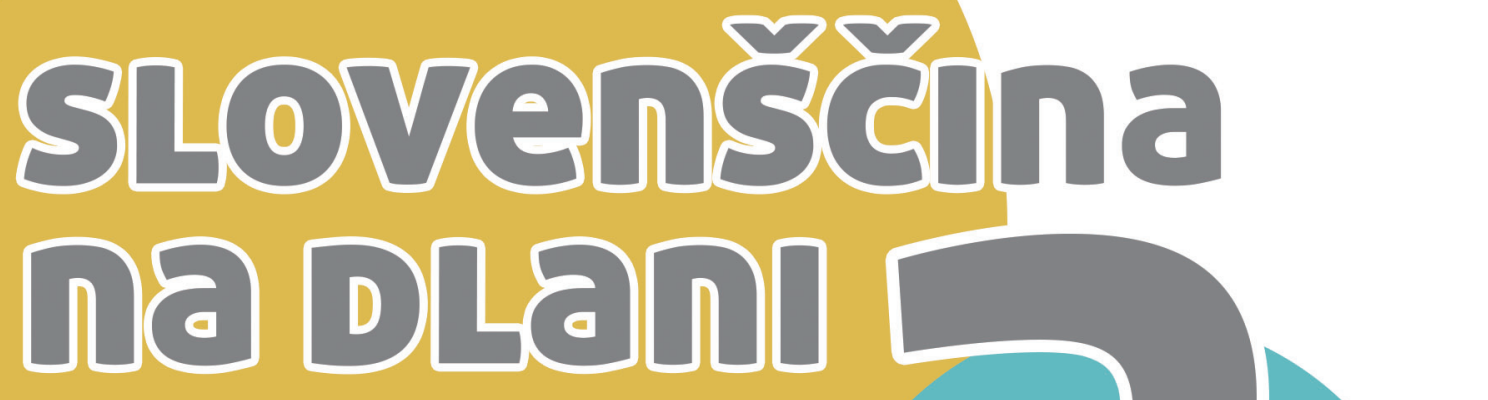



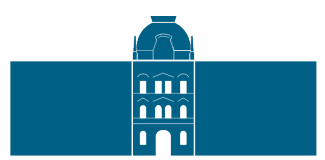

Univerza v Mariboru

Pedagoška fakulteta

Slovenščina na dlani 2

Urednica

Natalija Ulčnik

November 2019 
Naslov Slovenščina na dlani 2

Title Slovene in the Palm of Your Hand 2

Urednica Natalija Ulčnik

Editor (Univerza v Mariboru, Filozofska fakulteta)

Avtorice in avtorji Mojca Jerala - Bedenk, Petra Kodre, Mihaela Koletnik, Mira Krajnc Authors Ivič, Eva Lajevec, Simona Majhenič, Sandi Majninger, Tjaša Markežič, Matej Meterc, Gordana Rodinger, Polonca Šek Mertük, Natalija Ulčnik, Alenka Valh Lopert, Darinka Verdonik, Nives Vidic in Ines Voršič

Recenzija Milena Ivanuš Grmek

Review (Univerza v Mariboru, Pedagoška fakulteta)

Mojca Šorli

(Univerza v Ljubljani, Filozofska fakulteta)

Jezikovni pregled Natalija Ulčnik

Language editing (Univerza v Mariboru, Filozofska fakulteta)

Polonca Šek Mertük

(Univerza v Mariboru, Pedagoška fakulteta)

Prevod povzetka Simona Majhenič

Abstract translation (Univerza v Mariboru, Filozofska fakulteta)

Tehnični urednik Jan Perša

Technical editor (Univerzitetna založba Univerze v Mariboru)

Oblikovanje ovitka Jan Perša

Cover designer (Univerzitetna založba Univerze v Mariboru)

Grafične priloge
Graphic material Avtorice in avtorji prispevkov

Založnik / Published by

Univerzitetna založba Univerze v Mariboru

Slomškov trg 15, 2000 Maribor, Slovenija

http://press.um.si, zalozba@um.si

\section{Izdajatelj / Co-published by}

Univerza v Mariboru, Pedagoška fakulteta

Koroška cesta 160, 2000 Maribor, Slovenija

https://pef.um.si/, dekanat.pef@um.si

\section{Izdaja
Edition}

\section{Vrsta publikacije}

Publication type

Dostopno na

Available at

Izdano

Published
E-knjiga

http://press.um.si/index.php/ump/catalog/book/447

Maribor, november 2019 
Projekt Slovenšina na dlani sofinancirata Ministrstvo za kulturo Republike Slovenije in Evropska unija iz Evropskega socialnega sklada. Projekt poteka na Univerzi v Mariboru v sodelovanju Filozofske fakultete, Fakultete za elektrotehniko, računalništvo in informatiko ter Pedagoške fakultete. Sodeluje 14 vzgojno-izobraževalnih zavodov iz vzhodne in zahodne kohezijske regije (Gimnazija Franca Miklošiča Ljutomer, Gimnazija Ormož, Prva gimnazija Maribor, OŠ Pesnica pri Mariboru, Šolski center Rogaška Slatina, OŠ Primoža Trubarja Laško, OŠ Sava Kladnika Sevnica, Šolski center Postojna, Gimnazija Tolmin, OŠ Danila Lokarja Ajdovščina, OŠ Naklo, OŠ Draga Bajca Vipava, Zavod sv. Frančiška Saleškega, OE Gimnazija Želimlje, OŠ Vižmarje - Brod Ljubljana).

\section{REPUBLIKA SLOVENIJA MINISTRSTVO ZA KULTURO}

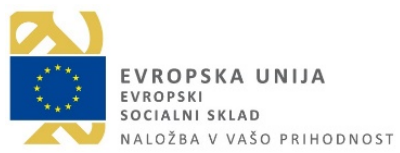

Publikacija je izšla v okviru projekta Slovenščina na dlani (JR-ESS-PROŽNE OBLIKE UČENJA). Naložbo sofinancirata Republika Slovenija in Evropska unija iz Evropskega socialnega sklada.

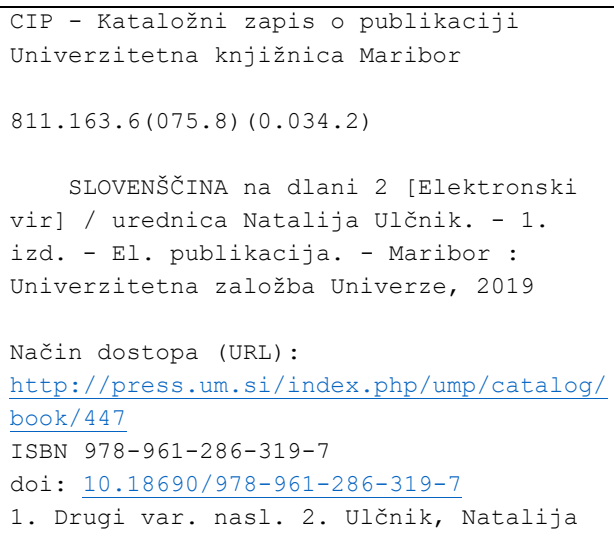

ISBN 978-961-286-319-7 (pdf)

DOI https://doi.org/10.18690/978-961-286-319-7

$$
\begin{array}{r}
\text { Cena } \\
\text { Price }
\end{array}
$$

Odgovorna oseba založnika prof. dr. Zdravko Kačič, For publisher rektor Univerze v Mariboru 



\title{
Slovenščina na dlani 2
}

\author{
NATALIJA UlČNIK
}

Povzetek Monografija predstavlja nadaljevanje publikacije Slovenščna na dlani 1, izdane $\mathrm{v}$ letu 2018. Prvi del prinaša rezultate projekta Slovenšina na dlani, ki ga v času od leta 2017 do leta 2021 izvajamo na Univerzi v Mariboru. Predstavljena je idejna zasnova učnega e-okolja, in sicer z vidika uporabniške izkušnje učitelja ter učenca. Ker bo eokolje vsebovalo vaje in naloge $s$ področja pravopisa, slovnice, frazeologije in besedil, so podane možnosti priprave vaj z ozirom na učni načrt in postopke avtomatizacije. Pri frazeologiji bomo ob nalogah ponudili tudi slovarske opise izbranih enot, zato je predstavljeno, katerih 100 frazemov in 100 pregovorov smo izbrali za natančnejšo obravnavo. Pojasnjeno je tudi, katera znanja bodo učeči se usvajali s pomočjo zbirke besedil, ki smo jo poimenovali BERTA. V drugem delu najdemo članke učiteljic slovenščine, ki sodelujejo $\mathrm{v}$ projektu. $\mathrm{Na}$ podlagi svojih izkušenj z učenci in dijaki predstavljajo izvirne ideje za obravnavo slovnice, leksikologije, frazeologije in besedilnih vrst ter izpostavljajo učinkovite učne metode, $\mathrm{s}$ katerimi so uspele osnovno- in srednješolce navdušiti za učenje in raziskovanje slovenščine. Na podlagi člankov ugotavljamo, da je mogoče vsako, tudi na videz suhoparno učno snov, učencem predstaviti kot izziv in jih s tem spodbuditi k ustvarjalnosti ter iskanju drugačnih rešitev.

Ključne besede: $\bullet$ e-okolje $\bullet$ tipologija nalog $\bullet$ pravopis $\bullet$ slovnica $\bullet$ frazeologija $\bullet$ neumetnostna besedila $\bullet$ pouk slovenščne $\bullet$ učne metode $\bullet$

\footnotetext{
NASLOv UREDNICE: Natalija Ulčnik, Univerza v Mariboru, Filozofska fakulteta, Maribor, Slovenija, epošta: natalija.ulcnik@um.si.
} 


\title{
Slovene in the Palm of Your Hand 2
}

\author{
NATALIJA ULČNIK
}

\begin{abstract}
The monograph is a continuation of the publication Slovene in the Palm of Your Hand 1. In the first part, the results of the project Slovene in the Palm of Your Hand, which is being carried out at the University of Maribor from 2017 until 2021, are presented. It outlines the e-environment for learning from the perspective of the teacher's and the pupil's user experience. As the e-environment provides exercises in orthography, grammar, phraseology, and texts, exercises can be prepared considering both the curricula and the process of automation. The area of phraseology will also include a dictionary description of selected units. Therefore, the 100 idioms and the 100 proverbs that were selected for a more detailed analysis are presented. The monograph also elaborates the knowledge that pupils will gain through the collection of texts, called BERTA. The second part provides papers by Slovene language teachers. Drawing upon their experience in working with pupils and high school students, they introduce original ideas for teaching grammar, lexicology, phraseology, and text types while highlighting effective teaching methods which inspired pupils and high school students to learn and research the Slovene language. The papers show that all subject matters, can be presented as challenges and therefore encourage learners to be more creative and search for alternative solutions.
\end{abstract}

Keywords: • e-environment - exercise typology • orthography • grammar $\bullet$ phraseology $\bullet$ non-literary text $\bullet$ Slovene lessons $\bullet$ teaching methods •

CORRESPONDENCE AdDRESS: Natalija Ulčnik, University of Maribor, Faculty of Arts, Maribor, Slovenia, e-mail: natalija.ulcnik@um.si. 


\section{Kazalo}

NA POTI K NOVEMU UČNEMU E-OKOLJU ZA

SLOVENŠČINO

Idejna zasnova e-okolja Slovenščina na dlani

Darinka Verdonik

Predlogi učiteljev za obravnavo vsebin v e-okolju

Polonca Šek Mertük

Pravopisne vaje $\mathrm{z}$ vidika ciljev učnih načrtov

Simona Majhenič

Avtomatsko ocenjevanje odgovorov na vprašanja odprtega tipa

Sandi Majninger

Tipologija nalog v aktualnih e-okoljih za slovenščino v srednjih šolah

Mihaela Koletnik in Alenka Valh Lopert

Izbor frazemov za bazo FRIDA

Natalija Ulčnik

Izbor pregovorov za bazo FRIDA

Natalija Ulčnik in Matej Meterc

Razvijanje funkcionalne pismenosti prek besedil zbirke BERTA

Mira Krajnc Ivič in Ines Voršič

Učenje slovnice s pomočjo zgodbe

Petra Kodre

Božič s priredjem in podredjem

Mojca Jerala - Bedenk 
Mladostniški sleng $\mathrm{v}$ manjših interesnih skupinah

Eva Lajevec

Frazeologija v očeh (prvo)gimnazijcev

Tjaša Markežič

Meni gre že vse na jetra!

Gordana Rodinger

Frazeologija v Prešernovem Povodnem možu

Nives Vidic

Kam bomo pa danes odpotovali?

Gordana Rodinger

Obravnava neumetnostnega besedila - neuradno pismo

Mojca Jerala - Bedenk

Oglaševanje nekoč in danes - obravnava besedilne vrste Tjaša Markežič 
NA POII! K NOVEMU UČNEMU
E-OKOLJU ZA SLOVENŠČINO 



\title{
Idejna zasnova e-okolja Slovenščina na dlani
}

\author{
DARINKA VERDONIK
}

Povzetek V članku predstavljamo idejno zasnovo, kako bo e-okolje Slovenscina na dlani videl uporabnik. Najprej predstavimo, katere izbire vidi učitelj in kako dodeljuje naloge učencem, nato opišemo še učenčev vidik uporabe. E-okolje Slovenšina na dlani gradi na čim bolj avtomatiziranem izvajanju vaj in nalog, da na ta način razbremeni učitelja pregledovanja in popravljanja odgovorov, hkrati pa mu omogoči enostavno sprotno, formativno spremljanje napredka vsakega učenca posebej ali pa posameznega razreda ali več razredov. V projektni skupini se trudimo, da bo e-okolje pregledno, razumljivo, intuitivno in grafično profesionalno oblikovano ter da bo upoštevalo priporočila za uporabnike z učnimi težavami.

Ključne besede: $\cdot$ učno e-okolje $\cdot$ interaktivnost $\cdot$ uporabniški vmesnik $\bullet$ avtomatizirane vaje $\bullet$ slovenščina $\bullet$

NASLOV AVTORICE: Darinka Verdonik, Univerza v Mariboru, Fakulteta za elektrotehniko, računalništvo in informatiko, Maribor, Slovenija, e-pošta: darinka.verdonik@um.si. 


\section{Uvod}

Vzporedno s pripravo baz, ki bodo vir primerov (Dobrovoljc 2018; Krajnc Ivič 2018), ter vaj in nalog za vse štiri vsebinske sklope (pravopis, slovnico, frazeme in pregovore ter besedila) v projektni ekipi že vse od začetka projekta razvijamo tudi zasnovo, kako bo uporabnik vstopal v e-okolje Slovenšina na dlani, kaj bo kje videl, kaj izbiral, kaj in kako lahko avtomatiziramo ..., skratka, kakšna naj bi bila uporabniška izkušnja. $\mathrm{V}$ tem prispevku na kratko povzamemo naše dosedanje zamisli in sklepe o tem, vse bralce pa toplo vabimo, da vsakršne pomisleke ali predloge, ki se jim ob branju utrnejo, pošljejo na e-naslov avtorice tega prispevka.

\section{E-okolje za učitelja}

Učitelju se po prijavi na uvodni strani prikažejo naslednje izbire:

- skupine (razredi, ki jih uči, ali druge skupine učencev, ki si jih želi določiti),

- gradiva (tukaj si lahko izdela teste, delovne liste, izpiske iz baze znanj ali slovarja frazemov in pregovorov),

- brskanje in iskanje po zavihku V sak zakaj ima svoj zato.

Če izbere skupine, vidi osnovne informacije o njih, lahko pa podrobneje poišče posameznega učenca ali več učencev. Nato lahko:

- dodeli naloge izbranim skupinam ali učencu/-em,

- pregleda rezultate izbrane skupine ali učenca,

- pošlje sporočilo izbranim skupinam ali učencu/-em.

Če želi učitelj učencem dodeliti naloge, so na izbiro štirje osnovni vsebinski sklopi:

- pravopisni oz. Vejico stresem iz rokava,

- slovnični oz. Slovnica v malem prstu,

- frazeološko-paremiološki oz. Zakladnica modrosti/Več znaš, več veljaš,

- besedilni oz. Iz malega zraste veliko. 
Znotraj teh sklopov lahko učitelj poljubno podrobno izbira posamezne teme ali podteme, ki so vključene $\mathrm{v}$ vsak sklop, in jih tudi poljubno kombinira. Učitelj pri dodeljevanju nalog ne izbira točno določenih primerov ali nalog, ki naj jih učenec opravi, ampak samo določi tematiko, ki naj jo vadi, in rok, do katerega mora učenec to narediti. Računalnik sam vodi učenca skozi tematiko, učitelj pa lahko v pregledu rezultatov sproti sledi, koliko je učenec vadil in koliko napredoval $\mathrm{v}$ znanju iz vsake posamezne tematike. Uspešen učenec lahko z manj vajami uspešno zaključi neko tematiko, učenec z več težavami pa se pri tematiki zadrži nekoliko dlje in ima na voljo tudi različne spodbude, kot so namigi, razlage, žetoni, da bi lažje napredoval v znanju.

Če želi učitelj izbrati točno določene vaje znotraj določene tematike, naredi to pod funkcionalnostjo priprave gradiva. Tam lahko tudi izvaja sprotna preverjanja znanja, pri katerih bodo vsi učenci reševali iste vaje $z$ istimi primeri, ali pa si pripravlja gradiva (npr. delovne liste) za natis. Pod funkcionalnostjo dodeljevanja nalog pa so vaje in naloge za vsakega učenca individualizirane in se avtomatizirano prilagajajo glede na to, kako uspešen je učenec pri reševanju.

Pri pregledu rezultatov lahko učitelj vidi rezultate razreda ali posameznega učenca $v$ razredu (odvisno od tega, kaj odkljuka). Vidi naslednje informacije:

- obseg in uspešnost reševanja nalog skozi grafične elemente (drevo znanja, značke),

- obseg in uspešnost reševanja nalog v podrobnih številkah/grafu,

- število in uspešnost tekmovanj, v katerih je sodeloval,

- možnost anonimne primerjave $z$ drugimi razredi in drugimi šolami, ki uporabljajo e-okolje,

- morebitne vnesene razlage, samoocene učencev ipd.

\section{E-okolje za učenca}

Učenec ima na uvodni strani na voljo izbire:

- reševanje vaj in nalog, ki mu jih je določil učitelj,

- individualno reševanje vaj in nalog (učenec si sam izbere, kaj bo vadil), 
- tekmovalno reševanje vaj in nalog (več učencev rešuje iste vaje in naloge ter pri tem tekmujejo, kdo je bolj uspešen),

- pregled rezultatov,

- brskanje in iskanje po zavihku Vsak zakaj ima svoj zato.

Če učenec izbere individualno ali tekmovalno reševanje vaj in nalog, se mu odprejo enake izbire kot učitelju, tj. med vsemi štirimi vsebinskimi sklopi si lahko poljubno podrobno (bodisi izbere samo sklop bodisi teme ali podteme znotraj enega sklopa bodisi kombinira teme iz dveh ali več sklopov ali pa ne izbere ničesar in dela naloge iz vseh štirih vsebinskih sklopov) in v poljubni kombinaciji izbere tematike, ki jih želi vaditi.

Računalnik učencu avtomatizirano določa različne vaje in naloge znotraj širše ali ožje definiranih tematik, kot jih je bodisi učenec izbral sam bodisi mu jih je določil učitelj, in mu pri večini vaj sproti avtomatsko ocenjuje uspešnost. Učenec pri vsaki tematiki ob prvem vstopu v to tematiko začne vaje na težavnostni stopnji, ki je predvidena kot izhodiščna za njegovo stopnjo šolanja, nato pa glede na uspešnost reševanja bodisi hitreje bodisi počasneje napreduje. Pri tem se hrani zgodovina učenčevih aktivnosti v e-okolju skozi celotno obdobje šolanja in učenec sebi prilagojeno vedno nadaljuje vaje in naloge iz posamezne tematike na težavnostni stopnji, na kateri je ostal. Če se mu kje zelo zatika, dobi k vajam definirane namige, razlage iz baze znanj, lahko unovči žeton in podobno, za učence višjih stopenj šolanja pa je $\mathrm{v}$ takih primerih $\mathrm{v}$ določenih sklopih predviden tudi avtomatiziran prehod na nižje zahtevnostne stopnje.

Učenec svoje rezultate vidi na podoben način kot učitelj, s tem da jih vidi samo zase. Prikaže se mu:

- obseg in uspešnost reševanja nalog skozi grafične elemente (drevo znanja, značke),

- obseg in uspešnost reševanja nalog s podrobnimi podatki v številkah/grafu,

- uspešnost tekmovanj, $v$ katerih je sodeloval,

- možnost anonimne primerjave z drugimi učenci na šoli ali v e-okolju nasploh,

- možnost vpogleda v morebitne lastne razlage, samoocene ipd.,

- število unovčenih in neunovčenih žetonov. 


\section{Vsak zakaj ima svoj zato}

Zavihek V sak zakaj ima svoj zato bo predvidoma vseboval tri opcije, med katerimi bo uporabnik lahko izbiral:

- brskanje ali iskanje po bazi znanja, ki bo vsebovala razlage, ki se bodo sicer prikazovale ob nalogah, kadar bo učenec potreboval ali zahteval dodatno razlago,

- brskanje in iskanje po slovarju frazemov in pregovorov,

- atlas pregovorov.

Učitelj bo lahko vsebine iz teh virov vključeval v delovne liste in drugo gradivo, ki ga bo želel pripraviti.

\section{Sklep}

V ekipi Slovenšcine na dlani se trudimo, da bo e-okolje zasnovano grafično profesionalno, všečno, razumljivo in intuitivno, zato skušamo izbire in funkcionalnosti narediti čim bolj pregledne. Prav tako pri izdelavi e-okolja sledimo priporočilom za uporabnike $z$ učnimi težavami ter jih integriramo v e-okolje, ob tem pa skrbimo, da na ta način ne okrnimo zastavljenih funkcionalnosti. Tudi sami pa se najbolj veselimo dne, ko bo izdelan grafični vmesnik in bodo vključene prve vaje, da bomo lahko delovanje e-okolja tudi preizkusili.

\section{Literatura}

Kaja DOBROVOLJC, 2018: Kako nastajajo korpusi. Slovenščna na dlani 1. Ur. Natalija Ulčnik. Maribor: Univerzitetna založba Univerze v Mariboru. 61-64.

Mira KRAJNC IVIČ, 2018: Kdo ali kaj je BERTA? Slovenščna na dlani 1. Ur. Natalija Ulčnik. Maribor: Univerzitetna založba Univerze v Mariboru. 65-72. 


\title{
Predlogi učiteljev za obravnavo vsebin v e-okolju
}

\author{
POLONCA ŠEK MERTÜK
}

Povzetek Učitelje, ki sodelujejo v projektu Slovenšina na dlani, smo povabili k sodelovanju pri sooblikovanju zasnove e-okolja Slovenšina na dlani. Na podlagi svojih pedagoških izkušenj so podali mnenja in predloge za izbor relevantnih tem za obravnavo $\mathrm{v}$ e-okolju. V prispevku predstavljamo ugotovitve oziroma opažanja učiteljev, pri katerih vsebinah imajo učenci in dijaki največ težav, katere se v šoli morda premalo obravnavajo in bi jih bilo dobro vključiti v e-okolje Slovenšcina na dlani. Predlagane teme predstavljamo po posameznih sklopih (pravopis, slovnica, frazemi, besedila) in glede na pogostost izpostavljene problematike oziroma potrebe po obravnavi.

Ključne besede: $\cdot$ pravopis $\cdot$ slovnica $\cdot$ frazemi - besedila $\bullet$ problematična mesta $\bullet$

NASLOv AVTORICE: Polonca Šek Mertük, Univerza v Mariboru, Pedagoška fakulteta, Maribor, Slovenija, e-pošta: polonca.sek@um.si. 


\section{Predlogi za obravnavo tem s področja pravopisa ${ }^{1}$}

Pri učencih je bila kot najbolj problematična zaznana raba velike in male začetnice. Učitelji menijo, da vaj za veliko in malo začetnico ni nikoli dovolj. Pri rabi velike začetnice so izpostavili problematiko pri lastnih imenih bitij, zemljepisnih lastnih imenih in stvarnih lastnih imenih, še posebej zapis prevzetih in tujih lastnih imen. Pri rabi male začetnice so izpostavili pisanje imen praznikov, zgodovinskih dogodkov, nagrad, gibanj, nazorov ter vrstnih pridevnikov iz lastnih imen. Učencem težave povzroča tudi pisanje skupaj in narazen, npr. pri zanikanju glagolov (ne vem, ne bo) in ustreznem zapisu glede na vlogo besed (zato in za to, potem in po tem). Zelo pogosta težava je vejica, še posebej v primeru večbesednih veznikov (potem ko, medtem ko, kot da, tako da). Od drugih ločil osnovnošolski učitelji izpostavljajo pisanje vezaja in pomišljaja ter ločil v premem govoru. Zaželeno bi bilo tudi več vaje pri deljenju besed ter pisanju krajšav (kratice, okrajšave, simboli), barv in njihovih odtenkov (zeleno-moder in zeleno moder oz. zelenomoder; opečnato rjav) ter težje zapisljivih besed.

Pri dijakih so učitelji kot najbolj problematične pravopisne teme zaznali pisanje vejice, rabo velike in male začetnice ter pisanje skupaj in narazen. Vejica dijakom povzroča precejšnje preglavice, še posebej v večstavčnih povedih, $v$ večbesednih veznikih (medtem ko, kljub temu da), pri nakopičenih podrednih veznikih ter pri zvezi prirednega in podrednega veznika, nekoliko manj pa je bila izpostavljena raba vejice pri pastavkih in polstavkih, saj se ti dve vrsti stavkov pojavljata v manjši meri. Učitelji opažajo, da je zapis vejice zahtevnejši, če je odvisni stavek na začetku povedi, vsekakor pa $\mathrm{v}$ zapleteno zloženih povedih. Pri rabi velike in male začetnice so srednješolski učitelji najpogosteje izpostavili pisanje zemljepisnih naselbinskih imen ter tudi problem ločevanja med zemljepisnimi naselbinskimi in nenaselbinskimi imeni (Kranjska Gora - Šmarna gora). V povezavi z zemljepisnimi imeni se kaže težava pri ločevanju med vrstnimi pridevniki na $-s k i,-5 ̌ k i$ in lastnim imenom (na slovenskem ozemlju - na Slovenskem) ter pri pisanju pridevnikov, ki so nastali iz zemljepisnih imen (strasbourški, bruseljski, nenyorškı). Pisanje skupaj in narazen je najbolj problematično pri zanikanih oblikah glagolov ( $n e$ bi, ne bo) in v primerih, ko je zapis lahko skupaj ali narazen (nemalo, veúvreden), odvisno od pomena. Presenetljivo je spoznanje, da nekateri dijaki skupaj pišejo tudi zveze predlogov in samostalnikov. Učitelji težavo zaznavajo tudi pri pisanju pridevniških zloženk skupaj oziroma $\mathrm{z}$ vezajem

\footnotetext{
${ }^{1}$ Predlagane teme osnovnošolskih in srednješolski učiteljev, ki sodelujejo v projektu Slovenšcina na dlani, so zbrane v Šek Mertük (2018).
} 
(poljudnoznanstven - pedagoško-znanstven). V manjši meri kot zapis vejice učitelji opažajo težave pri pisanju vezaja, pomišljaja in podpičja, kar je razumljivo, saj se ta ločila pri učencih uporabljajo bistveno redkeje kot vejica. Nekaj učiteljev je opozorilo na potrebo po vaji zapisovanja besed s polglasnikom (ministrski, septembrski), besed s sklopoma lj/mj (globlii, nadaljnji, zvonjenje, življenjski) ter drugih težje zapisljivih besed (poizkus/poskus, udreti/vdreti, udor/vdor). Več vaje bi potrebovali pri pisanju prevzetih besed (blues, renault, murikeal). Učitelji so izpostavili tudi stičnost in nestičnost ločil, predvsem pri piki in tropičju, pisanje ločil pri premem govoru ter deljenje besed. Predlagano je bilo, da bi za vajo popravljanja pravopisnih napak dijakom ponudili težja besedila s čim bolj različnimi in čim manj opaznimi pravopisnimi napakami.

\section{Predlogi za obravnavo tem s področja slovnice}

Za sklop slovnica so osnovnošolski učitelji navedli zelo raznolike teme, ki so učencem težje razumljive. Zanimivo je, da se predlagane slovnične teme največkrat dotikajo pridevnika, npr. tvorbe pridevnikov iz samostalnikov (Slovenija - slovenski; december - decembrski, Koper - koprski), določne in nedoločne oblike ( $\stackrel{c}{r} n$ - črni krub), vrste pridevnikov, razlike med lastnostnimi in vrstnimi pridevniki (težk glava - zeljna glava) ter stopnjevanja pridevnikov. Učitelji pri učencih opažajo težave pri prepoznavanju posameznih besednih vrst (samostalnikov, glagolov, pridevnikov, prislovov, predlogov, veznikov, členkov) ter pri razlikovanju med besednimi vrstami in skladenjsko vlogo, ki jo opravlja posamezna besedna vrsta $\mathrm{v}$ stavku (prislovno določilo - prislov, glagol-povedek). Pri obravnavi samostalnikov izstopa potreba po vaji rabe edninskih in množinskih samostalnikov (npr. starši-starša - starš). Učenci imajo težave pri sklanjanju samostalnikov (raba v povedi), zlasti posebnosti (navajajo npr. človek, človeka, ljudje; gospa; minister, mati, bři; Miha, Robi, dan; drva, vrata; škatla, ladja, mo ̌̌, lasje) in tujih imen. Pri glagolu je bilo izpostavljeno določanje glagola, razlika med morati in moři, raba nedoločnika in namenilnika, glagol biti v pretekliku in prihodnjiku ob polnopomenskem glagolu ter glagolski vid in naklon. Tudi zaimki učencem povzročajo nemalo težav, od prepoznavanja (vrsta), sklanjanja, še posebej pa, kdaj uporabiti osebni in kdaj povratni osebni zaimek, kdaj naglasno in kdaj naslonsko ali navezno obliko, kdaj zaimek ves in kdaj zaimek cel, kdaj povratni svojilni in kdaj svojilni zaimek $(m o j-s v o j)$. Pri števnikih je bila zaznana problematika v zvezi z njihovim zapisovanjem. Omenjena je bila težava pri razlikovanju med besednimi vrstami (pridevnik ali prislov) ter med stavčnimi členi (prislovno določilo ali predmet). V ta sklop uvrščamo tudi nasvet glede vaje rabe stavčnih členov, rabe 
podredno in še zlasti priredno zložene povedi, pretvarjanja premega govora $\mathrm{v}$ odvisni govor ter navajanje virov na koncu zapisanega besedila.

Srednješolski učitelji so za ta sklop podali zelo raznolike predloge. Za noben njihov predlog ne moremo reči, da se je pojavil večkrat kot drugi, zato predlagane vsebine predstavljamo tematsko. $\mathrm{Na}$ glasoslovni ravnini je bil izpostavljen izgovor besed, postavljanje naglasnih znamenj, iskanje naslonk v povedi ter posebej izgovor ozkega in širokega 0 . Pri besedoslovju učitelji izpostavljajo težave pri prevzetih besedah, ko je treba zapisati domačo sopomenko, ločevanje med večpomenkami in enakozvočnicami ter iskanje sopomenk/protipomenk. Učitelji v srednjih šolah si želijo vaje iz besedotvorja, to je določanje skladenjskih podstav pri sestavljenkah, zloženkah, sklopih (izpeljanke načeloma niso problem). Težave v oblikoslovju so predstavili bolj podrobno. Pri samostalniku je problematično zlasti sklanjanje, sploh posebnosti (mati, hrü, gospa, človek), raba rodilnika ob zanikanem glagolu ter raba neimenovalniških sklonov prevzetih lastnih imen (Shakespeare). Srednješolski učitelji pri pridevniku opažajo težave pri tvorbi svojilnih pridevnikov iz samostalnikov moškega in srednjega spola (Mihov, Janšev, pismonošev, vojvodov), vrstnih pridevnikov iz samostalnikov ženskega spola (limonov, palmov, smetanov in ne limonin, palmin, smetanin), rabo določne in nedoločne oblike ter rabo svojilnega pridevnika (npr. namesto babičn dijaki uporabljajo rodilniško obliko od babice). Od števnikov je bila izpostavljena le raba števnika en in njegove posamostaljene oblike eden. Zaimki dijakom povzročajo težave pri rabi ustrezne različice ki/kateri, v sklonski zamenjavi dajalnika in mestnika (pri njemu namesto pri njem) ter pri rabi povratnega svojilnega zaimka. Tako kot v osnovni šoli je tudi v srednji še vedno težava razlikovanje med osebnimi in povratnimi osebnimi zaimki ter med svojilnimi in povratnimi svojilnimi zaimki. Pri glagolu je podobno kot $\mathrm{v}$ osnovni šoli največja težava ustrezna raba glagolov moči/morati, hoteti/ šlelti ter nedoločnika in namenilnika. Pozornost je treba nameniti tudi spreganju v dvojini (oba spola, sploh preteklik), velelniku, vezljivosti (npr. dvomiti v koga/ kaj namesto o kom/ o čm) ter ujemanju povedka in osebka (Jesenice so slovensko mesto.) Pri predlogih je bila zaznana težava le $\mathrm{v}$ izbiri ustrezne različice $(k / h, z / s, n a / z, s, v / i z / z, s)$. Od prislovov je bila izpostavljena raba prislova več. S skladenjskega vidika je zagotovo najbolj problematična vejica (omenjeno že pri pravopisu), posebej $\mathrm{v}$ večstavčnih povedih. Nujne bi bile vaje za določanje in podčrtovanje stavčnih členov, dopolnjevanje povedi z zahtevanimi stavki (priredja, podredja), pretvorbe stavčnih členov $\mathrm{v}$ odvisnike in obratno, pretvorbe večstavčnih povedi $\mathrm{v}$ enostavčne, pretvorbe premega govora $\mathrm{v}$ odvisnega in obratno. Kot zelo zaželene so se pokazale vaje za določanje S-struktur. 


\section{Predlogi za obravnavo tem s področja frazeologije}

Za obravnavo frazemov v osnovni šoli je bilo manj predlogov kot za srednjo šolo, saj je teh vsebin v osnovni šoli manj kot v srednji. Učitelji za učence predlagajo vaje za rabo in razlago frazemov - njihov pomen in rabo $\mathrm{v}$ vsakdanjih govornih okoliščinah. Učitelji ugotavljajo, da učenci frazemov ne poznajo. Predlagajo naloge povezovanja - frazem $\mathrm{v}$ enem stolpcu, njegova razlaga $\mathrm{v}$ drugem, dopolnjevanja zaključka besedil z ustreznimi frazemi (učenci imajo na eni strani besedila, na drugi pa nabor frazemov). Te vaje se jim zdijo pomembne, saj menijo, da učenci vedno slabše razumejo frazeme in pregovore. Razloge vidijo v tem, ker učenci manj berejo in ne živijo toliko v širših družinskih skupnostih, kjer bi se frazemov naučili od starejših.

Srednješolski učitelji so za frazeološki sklop predlagali ločevanje med nezaznamovanimi stalnimi besednimi zvezami in frazemi, iskanje frazemov $\mathrm{v}$ izhodiščnem besedilu, iskanje sopomenskih/protipomenskih frazemov, povezovanje med frazemi in njihovim pomenom, popravljanje frazemov (npr. gre kot megla), dopolnjevanje frazemov/pregovorov (npr. mladost je norost ...), razlago (parafrazo) frazemov. Zaželene bi bile vaje za izražanje s pomočjo frazemov (spreminjanje besednih zvez z neprenesenim pomenom v frazeme). Opažajo, da dijaki slabo poznajo pomen posameznih frazemov in obratno, npr. če imajo pomen napisan, nastopijo težave, ko morajo sami napisati ustrezni frazem (ali k danemu frazemu zapisati protipomenskega, sopomenskega ...).

\section{Predlogi za obravnavo tem na področju besedil}

Osnovnošolski učitelji so za sklop besedil predlagali vaje pisanja različnih besedilnih vrst (prošnja, opravičilo, zahvala, vabilo, poročilo, ocena, opis, pripoved), v katerih bi učenec povezal ime besedilne vrste $z$ besedilom. Kot potrebno ocenjujejo vajo za zmožnost strnitve iz daljšega besedila v krajšo različico - obnovo (npr. v 6 povedih). Pomembne se jim zdijo tudi vaje, s katerimi bi učenci ob določenih zahtevah tvorili krajša samostojna besedila (tvorbne naloge) in krajše zaokroženo besedilo zapisali s pomočjo podvprašanj. Učenci naj bi prepoznavali tudi nebesedne prvine besedila in ugotavljali manjkajoče podatke $\mathrm{v}$ besedilu. Tudi vaje, s katerimi bi utrjevali in preverjali literarnovedne pojme, literarna obdobja, bi bile po mnenju učiteljev dobrodošle. 
Večjo problematiko $\mathrm{v}$ povezavi z besedili opazimo pri srednješolskih učiteljih. Svetujejo vaje za določanje vrste besedila glede na namen, funkcijo, sporočevalca, naslovnika ..., prepoznavanje besedilnih vrst, ločevanje med posameznimi vrstami (poročilo, reportaža, komentar) ter izbiro ustrezne besedilne vrste glede na predstavljene okoliščine. Učitelji opažajo, da imajo dijaki težave pri (kratkem) povzemanju odstavkov in celotnega besedila, členjenju besedila ter določanju glavne teme in podtem (pogosto glavno temo zamenjajo s katero od podtem). $V$ povezavi $\mathrm{s}$ tem predlagajo pisanje/dodajanje naslovov in mednaslovov. Kot težavno so zaznali tudi določanje slogovnih postopkov/načinov razvijanja teme ter prepoznavanje okoliščin sporočanja. V besedilih od dijakov pričakujejo tudi popravljanje napak $\mathrm{v}$ razumljivosti, jasnosti, zaokroženosti besedila in slogovno popravljanje besedila (jedrnatost, pogovorne tvorbe povedi), postavljanje ključnih vprašanj, povezanih z vsebino, izbiranje napačnih oz. pravilnih trditev o vsebini besedila, razlago pomenov posameznih izrazov iz besedila (npr. terminov, prevzetih besed). Težave nastopijo tudi, kadar je treba iz besedila izpisati besede/besedne zveze, ki kažejo na to, da je besedilo subjektivno, objektivno, publicistično, strokovno ali poljudnoznanstveno. Pozornost bi morali nameniti tudi zgradbi besedila.

\section{Sklep}

Učitelji iz osnovnih in srednjih šol, ki sodelujejo v projektu Slovenš̌ina na dlani, so nam na podlagi svojih pedagoških izkušenj podali predloge tem, ki naj bi jih vključili v e-okolje Slovenšcina na dlani. Gre za teme, pri katerih imajo učenci in dijaki največ težav in za katere učitelji želijo, da bi jim e-okolje nudilo več vaj. Iz predstavljenega lahko ugotovimo, da so temeljne težave pri vseh sklopih podobne tako pri učencih kot pri dijakih, npr. raba velike in male začetnice, pisanje skupaj in narazen, raba vezaja in pomišljaja, pisanje zanikane oblike glagola; sklanjanje težjih samostalnikov, raba osebnega/povratnega osebnega zaimka, raba nedoločnika/namenilnika; razlaga in tvorjenje frazemov ... Iz tega sledi, da se neusvojena snov iz osnovne šole prenese $\mathrm{v}$ srednjo šolo. Verjamemo, da bo novo e-okolje Slovenšñna na dlani tudi zaradi predlogov, opažanj in ugotovitev sodelujočih učiteljev omenjeno problematiko uspešno zmanjšalo, če že ne odpravilo.

\section{Literatura}

Polonca ŠEK MERTÜK, 2018: Predlagane teme za vključitev v e-okolje. Gradivo projekta Slovenščina na dlani. Maribor: Univerza v Mariboru. 


\title{
Pravopisne vaje $z$ vidika ciljev učnih načrtov
}

\author{
SIMONA MAJHENIČ
}

Povzetek Naloge za utrjevanje znanja o pravopisu, ki jih pripravljamo $\mathrm{v}$ okviru učnega e-okolja za slovenščino, dosegajo in presegajo cilje in standarde znanj, določene $\mathrm{v}$ učnih načrtih, zato bodo učitelju nudile koristen vir dodatnih vaj za učence. Obenem so sestavljene tudi iz tistih tipov nalog, ki so posebej priljubljeni pri učencih. Tako bodo učenci motivirani, da bodo znanje pridobivali na sodoben in njim prilagojen način.

Ključne besede: $\cdot$ cilji $\bullet$ učni načrt $\cdot$ tretje vzgojno-izobraževalno obdobje $\bullet$ tipi nalog $\bullet$ standardi znanj $\bullet$

NASLOV AVTORICE: Simona Majhenič, Univerza v Mariboru, Fakulteta za elektrotehniko, računalništvo in informatiko, Maribor, Slovenija, e-pošta: simona.majhenic@um.si. 


\section{Uvod}

V okviru učnega e-okolja Slovenščna na dlani na osnovi korpusa MAKS (več o korpusu v Dobrovoljc 2018) pripravljamo naloge iz pravopisa, ki jih bodo lahko učitelji uporabljali kot dopolnitev ali popestritev pouka ali kot dodatne naloge za utrjevanje znanja iz pravopisa. Obenem bo e-okolje omogočalo večjo vključenost učenca v proces načrtovanja učenja (prim. Pulko, Zemljak Jontes 2018) z možnostjo individualnega reševanja nalog, pri čemer se bo lahko sam odločil, kdaj in (deloma) kaj želi vaditi, sistem pa mu bo ponujal povratne in druge koristne informacije. Da bi bila raba učnega e-okolja čim bolj učinkovita, smo pri snovanju nalog upoštevali tako cilje in standarde znanj obstoječih učnih načrtov kot tudi ugotovitve o tem, kateri tipi nalog so bolj in kateri manj priljubljeni pri primarni skupini ciljnih uporabnikov - učencih (glej Koletnik, Lopert 2018).

\section{Pregled ciljev in standardov znanj, udejanjenih v nalogah za pravopis}

$\mathrm{V}$ nadaljevanju so predstavljeni cilji in standardi znanj iz učnega načrta za slovenščino (UN 2018) za tretje vzgojno-izobraževalno obdobje, ki smo jih upoštevali pri oblikovanju nalog iz pravopisa.

Učenci in učenke razvijajo jezikovne in slogovne zmožnosti tako, da:

- ob zapisanih besedah, povedih in besedilih utrjujejo oz. spoznavajo in nadgrajujejo:

- zapis besed s kritičnimi glasovi,

- izbiro različice predloga $z / s$ in $k / h$,

- zapis glavnih in vrstilnih števnikov s številkami in z besedami,

- zapis prevzetih besed,

- zapis eno- in večbesednih lastnih imen bitij, zemljepisnih in stvarnih lastnih imen,

- zapis svojilnih pridevnikov iz lastnih imen bitij,

- zapis imen prebivalcev krajev, držav, pokrajin, celin,

- zapis vrstnih pridevnikov iz zemljepisnih lastnih imen,

- zapis občnih imen, nastalih iz lastnih,

- zapis imen praznikov, jezikov, pripadnikov ras, zgodovinskih obdobij in dogodkov, pripadnikov obdobij, gibanj, nazorov in strank, 
- zapis imen barv oz. njihovih odtenkov,

- zapis zaimenskih, prislovnih in vezniških sklopov,

- rabo končnih ločil v eno- in večstavčnih povedih,

- rabo vejice $\mathrm{v}$ večstavčnih povedih ter $\mathrm{v}$ povedih s polstavki in pastavki,

- zapis premega govora (s spremnim stavkom pred dobesednim navedkom ali za njim),

- rabo dvodelnega in predložnega pomišljaja,

- $\quad$ rabo vezaja $\mathrm{v}$ prirednih zloženkah in $\mathrm{v}$ besedah, katerih prva sestavina je črka/številka,

- rabo treh pik,

- zapis krajšav,

- naštevanje v stolpcih,

- navajanje virov na koncu besedila;

- pri pisanju si po potrebi pomagajo s pravopisnimi priročniki v knjižni in elektronski obliki, pri oblikovanju besedil z računalnikom pa uporabljajo tudi urejevalnike, pregledovalnike in črkovalnike besedil;

- svoja besedila členijo na odstavke, v njih upoštevajo pravopisna pravila, skrbijo za čitljivost in estetskost pisave ter se odločijo za pisanje s pisanimi oz. tiskanimi črkami;

- prepoznajo pravopisne napake v svojih besedilih in v besedilih drugih, jih odpravijo in utemeljijo svoje popravke; pri tem si po potrebi pomagajo z raznimi jezikovnimi svetovalnicami ter s pravopisnimi priročniki v knjižni in elektronski obliki;

- primerjajo osnovna slovenska pravopisna pravila s tujimi in predstavijo svoje ugotovitve (UN 2018: 36).

Pravopisno zmožnost kot del jezikovne in slogovne zmožnosti pa učenec pokaže tako, da:

- $\quad$ v besedah pravilno zapisuje glasove in glasovne sklope (7., 8., 9. razred);

- piše predlog ločeno od besede (7., 8., 9. razred);

- izbere pravilno različico predlogov $z / s$ in $k / h$ (7., 8., 9. razred);

- piše nikalnico ne ločeno od glagola (7., 8., 9. razred);

- pravilno deli domače besede (7., 8., 9. razred); 
- pravilno piše glavne in vrstilne števnike s številkami in z besedami (7., 8., 9. razred);

- pravilno piše prevzete besede (7., 8., 9. razred);

- piše začetek povedi z veliko začetnico (7., 8., 9. razred);

- pravilno piše eno- in večbesedna lastna imena bitij (7., 8., 9. razred);

- pravilno piše imena prebivalcev krajev, držav, pokrajin, celin (7., 8., 9. razred);

- pravilno piše svojilne pridevnike, izpeljane iz lastnih imen bitij (7., 8., 9. razred);

- pravilno piše eno- in večbesedna zemljepisna lastna imena (7., 8., 9. razred);

- pravilno piše vrstne pridevnike, izpeljane iz zemljepisnih lastnih imen (7., 8., 9. razred);

- pravilno piše eno- in večbesedna stvarna lastna imena (7., 8., 9. razred);

- pravilno piše imena dni in mesecev (7., 8., 9. razred);

- pravilno piše imena praznikov (7., 8., 9. razred);

- pravilno piše imena jezikov (7., 8., 9. razred);

- pravilno piše imena pripadnikov ras (7., 8., 9. razred);

- pravilno piše občna imena, nastala iz lastnih (7., 8., 9. razred);

- pravilno uporablja končna ločila v eno- in večstavčnih povedih (7., 8., 9. razred);

- pravilno uporablja vejico pri naštevanju, $\mathrm{v}$ večstavčnih povedih ter $\mathrm{v}$ povedih s polstavki in pastavki (7., 8., 9. razred);

- pravilno uporablja ločila in veliko začetnico v premem govoru (s spremnim stavkom pred dobesednim navedkom ali za njim) (7., 8., 9. razred);

- pravilno uporablja oklepaj (7., 8., 9. razred);

- pravilno piše krajšave (7., 8., 9. razred);

- zna uporabljati pravopisne priročnike $\mathrm{v}$ knjižni in elektronski obliki, pri oblikovanju besedil z računalnikom pa zna kritično uporabljati tudi urejevalnike, pregledovalnike in črkovalnike besedil (8., 9. razred);

- $\quad \mathrm{v}$ svojih besedilih in $\mathrm{v}$ besedilih drugih prepozna pravopisne napake, jih odpravi in utemelji svoje popravke (7., 8., 9. razred) (UN 2018: 58-59). 


\section{Primer: preverjanje pravopisne zmožnosti}

Cilje in standarde znanj smo v učnem e-okolju udejanjili z nalogami različnih tipov, in sicer tistih, za katere se je v okviru raziskave (Koletnik, Lopert 2018) izkazalo, da so med učenci priljubljeni. Ti tipi med drugim vključujejo naloge izbirnega tipa z enim pravilnim odgovorom, alternativnega tipa, naloge označevanja in naloge povezovanja. Kot primer navajamo grafični koncept ${ }^{1}$ prikaza naloge za preverjanje pravopisne zmožnosti pri eno- ali večbesednih lastnih imenih bitij, in sicer v obliki naloge »sestavljanke«, pri čemer gre za modifikacijo naloge izbire pravilnega odgovora. Pri tem tipu naloge je poved razdeljena na dva dela, in sicer je prvi del povedi nespremenjen, drugi pa se pojavi $\mathrm{v}$ (recimo) treh različicah, med katerimi je samo ena pravilna. Uporabnik del s pravilno različico priključi prvemu delu.

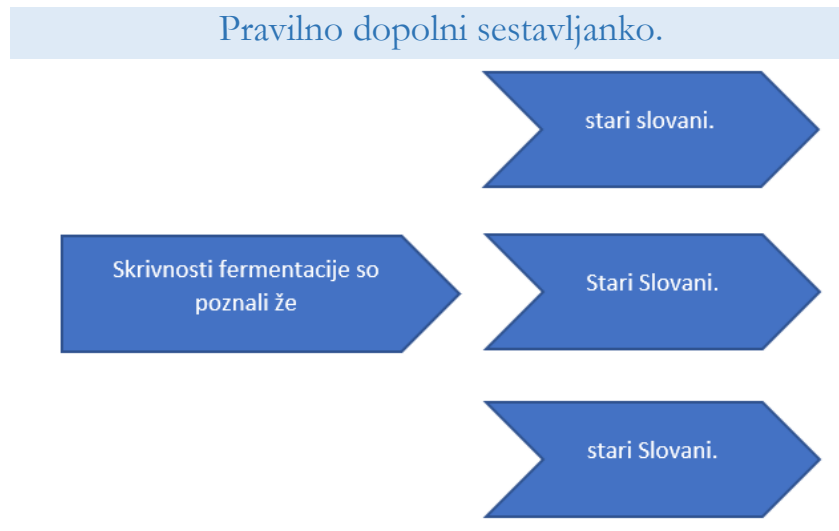

\section{Slika 1: Koncept naloge izbiranja}

Za razvijanje zmožnosti prepoznavanja napak smo med drugim pripravili naloge alternativnega tipa, izbirnega tipa, popravljanja, razvrščanja, sestavljank, iskanja besed $\mathrm{v}$ mreži in iskanja napak istega tipa. Slika 2 prikazuje nalogo dopolnjevanja $\mathrm{s}$ pomočjo mreže, kjer mora uporabnik razlikovati med pravilnim in nepravilnim zapisom in nato s pravilnim poved dopolniti.

\footnotetext{
${ }^{1}$ Gre le za stiliziran prikaz naloge. Končna grafična podoba, navodila in vsebina naloge se bodo lahko od te razlikovali.
} 
Dopolni z besedo, ki jo najdeš v mreži.

Rimljani svojih pitnih daritev niso prinašali samo Jupitru in in $z$ njima povezanim

božanstvom, ampak tudi Fortuni, boginji steče.

\begin{tabular}{|c|c|c|c|c|c|c|c|c|c|}
\hline $\mathrm{t}$ & 0 & $p$ & $\mathrm{n}$ & č & $\mathrm{j}$ & $\mathrm{m}$ & $\mathrm{R}$ & $\mathrm{e}$ & $\mathrm{e}$ \\
\hline $\mathrm{g}$ & b & $v$ & $\mathrm{e}$ & $\mathrm{n}$ & e & $r$ & $\mathrm{i}$ & d & $\check{c}$ \\
\hline z & $\mathrm{T}$ & ž & $r$ & a & $\mathrm{j}$ & š & V & č & $\mathrm{s}$ \\
\hline J & $p$ & $\mathrm{~F}$ & $\mathrm{i}$ & $\mathrm{T}$ & $\mathrm{m}$ & $\mathrm{u}$ & e & $\mathrm{h}$ & $p$ \\
\hline K & $\mathrm{h}$ & $\mathrm{n}$ & $p$ & I & k & Ž & $\mathrm{n}$ & $\mathrm{E}$ & b \\
\hline $\mathrm{d}$ & b & $p$ & h & D & e & $d$ & $\mathrm{e}$ & $r$ & $\mathrm{u}$ \\
\hline$p$ & $\mathrm{e}$ & d & B & $p$ & $\mathrm{k}$ & z & $r$ & C & C \\
\hline z & s & e & $\mathrm{e}$ & $\mathrm{h}$ & $\mathrm{v}$ & k & $\mathrm{i}$ & a & č \\
\hline C & R & $t$ & $r$ & J & $v$ & $\mathrm{~g}$ & $\mathrm{i}$ & d & $\mathrm{i}$ \\
\hline S & G & $r$ & i & č & $\mathrm{t}$ & $\mathrm{m}$ & k & Š & $p$ \\
\hline
\end{tabular}

Slika 2: Koncept naloge iskanja besed v mreži

\section{Sklep}

Zasnova nalog, ki jih za pravopis pripravljamo v okviru učnega e-okolja, omogoča individualizacijo in diferenciacijo, kot jo priporoča učni načrt (Poznanovič Jezeršek 2018: 73), obenem pa omogoča tudi razvijanje zmožnosti pisanja, skladenjske zmožnosti, poimenovalne in metajezikovne zmožnosti. Cilji nalog v e-okolju dosegajo in presegajo cilje, določene z učnimi načrti, zato bo e-okolje koristen pripomoček tako za učitelja kot učenca, ki bo lahko $\mathrm{v}$ okviru individualne samoiniciativne vadbe pridobival znanje na način, ki si ga želi in ki ga bo motiviral.

\section{Literatura}

Kaja DOBROVOLJC, 2018: Kako nastajajo korpusi. Slovenšcina na dlani 1. Ur. Natalija Ulčnik. Maribor: Univerzitetna založba Univerze v Mariboru. 61-64.

Mihaela KOLETNIK, Alenka VALH LOPERT, 2018: Tipologija nalog v aktualnih e-okoljih za slovenščino v OŠ. Slovenščna na dlani 1. Ur. Natalija Ulčnik. Maribor: Univerzitetna založba Univerze v Mariboru. 55-60.

Simona PULKO, Melita ZEMLJAK JONTES, 2018: Po inovativni poti do znanja. Slovenšcina na dlani 1. Ur. Natalija Ulčnik. Maribor: Univerzitetna založba Univerze v Mariboru. 49-54.

Mojca POZNANOVIČ JEZERŠEK idr., 2018: Učni načrt. Slovenščna. Ljubljana: Ministrstvo za šolstvo in šport, Zavod RS za šolstvo. Dostopno 29. 9. 2019 na:

https://www.gov.si/assets/ministrstva/MIZS/Dokumenti/Osnovna-sola/Ucni-

nacrti/obvezni/UN_slovenscina.pdf. 


\title{
Avtomatsko ocenjevanje odgovorov na vprašanja odprtega tipa
}

\author{
SANDI MAJNINGER
}

\begin{abstract}
Povzetek Prispevek opisuje idejni postopek, ki ga lahko uporabimo za avtomatsko ocenjevanje odgovorov na vprašanja odprtega tipa. Glavni korak $\mathrm{v}$ metodi je ugotavljanje pomena iz besedila in predstavitev izluščenih informacij na računalniku razumljiv način. Tak postopek lahko uporabimo v učnih e-okoljih in tako odpravimo njihovo ključno omejitev, ki omejuje nabor tipov nalog na tiste, ki jih je enostavno avtomatsko oceniti. S pomočjo tega postopka lahko učečim ponudimo tudi vaje za doseganje tistih učnih ciljev, ki se povezujejo z najvišjimi taksonomskimi stopnjami.
\end{abstract}

Ključne besede: • avtomatsko ocenjevanje • ugotavljanje pomena • obdelava naravnega jezika • ontologije • učno e-okolje •

NASLOV AVTORJA: Sandi Majninger, Univerza v Mariboru, Fakulteta za elektrotehniko, računalništvo in informatiko, Maribor, Slovenija, e-pošta: sandi.majninger@um.si. 


\section{Uvod}

Učna e-okolja so zelo uporabna $\mathrm{v}$ procesu učenja, saj uporabnikom omogočajo takojšnje povratne informacije o pravilnosti odgovorov. E-okolja pogosto vsebujejo le tipe nalog, ki jih je enostavno avtomatsko oceniti. To so vprašanja zaprtega tipa, naloge $z$ dopolnjevanjem ter vstavljanjem posameznih besed in podobno. Vaje za doseganje učnih ciljev, ki so na taksonomskih stopnjah uvrščeni najvišje, običajno vključujejo vprašanja odrtega tipa. Ocenjevanje odgovorov na taka vprašanja ni enostavno. Kljub temu lahko iz odgovora izvlečemo precej povratnih informacij in jih zberemo $\mathrm{v}$ obliki približne ocene, ki poleg številske vrednosti zajema tudi informacije o napakah.

Avtomatiziran postopek ocenjevanja odgovorov na vprašanja odprtega tipa se zgleduje po človeškem ocenjevanju. Končna ocena je sestavljena iz več postavk. Upoštevati mora tako slovnično pravilnost zapisanega odgovora kot tudi njegovo pomensko ustreznost. Pri daljših odgovorih z več stavki je pri oceni smiselno upoštevati tudi koherentnost besedila. Postopek najprej izračuna ocene za posamezne postavke, nato pa jih združi v končno oceno. Pri vsaki postavki lahko poleg številske vrednosti ocene odkrijemo tudi vzroke za morebitne znižane ocene. Te podatke lahko združimo $\mathrm{v}$ pregledno poročilo za uporabnika, ki bo poleg številske ocene dobil tudi obrazložitev in pojasnila.

\section{Ocenjevanje slovnične pravilnosti odgovora}

Avtomatskega ocenjevanja slovnične pravilnosti besedila se običajno lotimo večnivojsko. Najprej ocenimo ustreznost zapisanih besed. Pri tem so nam v pomoč orodja, ki preverjajo pravilnost črkovanja posameznih besed. Za ta korak potrebujemo slovarje in leksikone, ki vsebujejo bogato besedišče obravnavanega jezika. Če želimo preveriti ustrezno rabo velike začetnice, moramo imeti tudi slovarje imenskih entitet, ki vsebujejo pravilno zapisana imena. Pri preverjanju stavčne strukture se opiramo na ročno določena slovnična pravila in na oblikoslovne ter skladenjske oznake, ki smo jih pridobili iz besedila. Pridobimo lahko skupno število napak v besedilu. Za vsako odkrito napako poznamo tudi položaj v besedilu, tako da lahko uporabniku izpišemo seznam napak. 


\section{Ocenjevanje pomenske pravilnosti odgovora}

Da bi računalnik lahko ocenil pomensko pravilnost odgovora, mora najprej čim bolje razumeti besedilo odgovora. $\mathrm{V}$ ta namen uporabljamo orodja za strojno obdelavo naravnega jezika, ki besedam v besedilu določijo slovnične lastnosti. Nato se nad besedilom izvede luščenje informacij, tako da se poiščejo entitete ter relacije med njimi. Izluščene informacije se hranijo v obliki usmerjenih povezanih grafov, ki jim pravimo ontologije. Vozlišča grafa predstavljajo entitete, medtem ko povezave med vozlišči izražajo relacije med entitetami. Število povezav v ontologiji lahko še povečamo s pomočjo sklepalnih pravil. Ta temeljijo na matematičnih lastnostih določenih relacij. Preden izvedemo sklepanje, je potrebno za vsako izmed relacij določiti, katere matematične lastnosti zanjo veljajo. To lahko storimo ročno ali pa z avtomatiziranimi postopki, $\mathrm{v}$ primeru da se relacija $\mathrm{v}$ obravnavanih besedilih pojavlja pogosto.

Da bi ocenili pravilnost trditev $\mathrm{v}$ odgovoru, moramo izluščene informacije iz odgovora primerjati s splošnim znanjem. Splošno znanje je ontologija, ki smo jo tvorili po enakem postopku iz množice besedil, ki ji pravimo baza. V bazo lahko vključujemo različna besedila. Najprimernejša so besedila iz baze znanja, učbenikov, slovarske definicije in podobno. $\mathrm{V}$ bazo lahko vključimo tudi predvidene pravilne odgovore in odgovore učencev, ki so jih ročno ocenili učitelji. S primerjavo obeh ontologij lahko ocenimo pomensko pravilnost podanega odgovora. Pri primerjavi ontologij lahko naletimo na različne scenarije. Prvi izmed njih je, da v ontologiji iz odgovora odkrijemo enako relacijo med entitetama, kot jo imamo zapisano v ontologiji iz splošnega znanja. To pomeni, da je trditev v besedilu pravilna. Druga možnost je, da v ontologiji iz odgovora odkrijemo novo relacijo, ki se ne pojavlja $\mathrm{v}$ ontologiji iz splošnega znanja. Takšna trditev se najbrž ne navezuje na tematiko, po kateri sprašuje naloga. Možno je tudi, da trditev izraža neko novo odkrito znanje, ki ga nismo vključili v bazo splošnega znanja. V primeru, da v odgovoru odkrijemo relacije, ki so neskladne oz. protislovne z ontologijo iz baze znanja, pomeni, da smo naleteli na napačne trditve $\mathrm{v}$ besedilu. $\mathrm{Na}$ koncu lahko poiščemo tudi relacije, ki se pojavljajo $\mathrm{v}$ ontologiji splošnega znanja, ne pojavijo pa se $\mathrm{v}$ ontologiji iz odgovora. Te relacije predstavljajo dejstva, ki v odgovoru niso navedena (Zupanc, Bosnić 2017). 
$\mathrm{Na}$ podlagi takšne primerjave lahko izračunamo končno oceno in uporabniku podamo točnejše informacije o pomenski pravilnosti podanega odgovora. Označimo lahko napačne trditve in tudi izpišemo dejstva, ki niso omenjena $\mathrm{v}$ odgovoru.

\section{Ocenjevanje koherentnosti besedila}

Pri daljših pisnih sestavkih, kot so npr. eseji ali daljši odgovori z več povedmi, nas zanima tudi, kako berljiv je sestavek v celoti. Da je besedilo zanimivo za bralca, mora biti koherentno (Morris, Hirst 1991). To pomeni, da se morajo povedi med seboj vsebinsko navezovati in si slediti v ustreznem zaporedju. Avtomatski postopki za ocenjevanje koherentnosti besedila temeljijo na primerjavi sosednjih, prekrivajočih se segmentov besedila. Za koherentna besedila je značilno, da se v sosednjih, prekrivajočih se segmentih pojavljajo skupne entitete. Rezultat takšnega postopka je odstotek, ki izraža koherentnost besedila. Dodatno lahko tudi odkrijemo dele besedila, v katerih je prišlo do nenadne spremembe v temi besedila (Lapata, Barzilay 2005).

\section{Združevanje ocen}

Postopek združevanja ocen posameznih postavk v končno oceno odgovora je močno odvisen od tipa naloge. Pri nekaterih tipih nalog je namreč slovnična pravilnost odgovora pomembnejša kot pri drugih. Podobno je s koherentnostjo besedila, ki je v primeru kratkih odgovorov sploh ni mogoče oceniti. Da bi poenotili postopek združevanja ocen pri različnih tipih nalog, moramo pri vsakem tipu določiti uteži za posamezno postavko, ki povedo, koliko določena postavka prispeva h končni oceni odgovora. Te uteži bi lahko nastavili ročno pri vsakem tipu naloge. $\mathrm{V}$ primeru, da pridobimo dovolj veliko množico ročno ocenjenih odgovorov, bi lahko na podlagi te množice tudi avtomatično izračunali ustrezne uteži na način, da bi postopek združevanja čim bolj posnemal ročnega ocenjevalca.

\section{Sklep}

Predstavljen postopek lahko uporabimo za ocenjevanje vprašanj odprtega tipa. To nam omogoča, da $\mathrm{v}$ učno e-okolje vključimo vaje za doseganje tistih ciljev, ki so uvrščeni najvišje na taksonomskih stopnjah. Postopek poleg številske ocene pridobi tudi koristne povratne informacije o napakah. Na podlagi teh informacij lahko 
odkrijemo morebitne pomanjkljivosti v znanju učenca ter mu ponudimo nasvete in vaje, ki mu bodo pomagale pri odpravi teh pomanjkljivosti. Rezultati, ki jih vrača postopek, niso povsem zanesljivi, saj programske rešitve še ne ponujajo stoodstotne natančnosti pri ugotavljanju pomena iz besedila. Zato avtomatski postopek ne more $\mathrm{v}$ celoti nadomestiti človeškega ocenjevalca, lahko pa učencem omogoča, da samostojno vadijo in izpopolnjujejo svoje znanje.

\section{Literatura}

Kaja ZUPANC, Zoran BOSNIĆ, 2017: Automated essay evaluation with semantic analysis. KnowledgeBased systems 120, 118-132.

Jane MORRIS, Graeme HIRST, 1991: Lexical Cohesion Computed by Thesaural Relations as an Indicator of the Structure of Text. Computational Linguistics 17, 21-43

Miralla LAPATA, Regina BARZILAY, 2005: Automatic Evaluation of Text Coherence: Models and Representations. IJCAI'05 Proceedings of the 19th international joint conference on Artificial Inteligence. 1085-1090. 


\title{
Tipologija nalog v aktualnih e-okoljih za slovenščino v srednjih šolah
}

\author{
MiHAELA KOLETNIK IN ALENKA VALH LOPERT
}

\begin{abstract}
Povzetek V prispevku predstavljamo rezultate analize prostodostopnih gradiv za pouk slovenščine $\mathrm{v}$ srednjih šolah glede na tipe nalog. Rezultati analize, ki kažejo neuravnoteženo zastopanost različnih tipov nalog, med katerimi prevladuje tip, ki je med učenci najmanj priljubljen, nam bodo $\mathrm{v}$ pomoč pri zasnovi e-gradiv za poučevanje slovenščine v okviru projekta. Z uvajanjem najsodobnejših jezikovnih tehnologij v učne procese poskušamo premagati omejitve obstoječih e-gradiv za učenje slovenščine.
\end{abstract}

Ključne besede: $\bullet$ didaktika $\bullet$ srednja šola $\bullet$ slovenski jezik $\bullet$ e-gradiva

- tipologija nalog・

NASLOVA AVTORIC: Mihaela Koletnik, Univerza v Mariboru, Filozofska fakulteta, Maribor, Slovenija, e-pošta: mihaela.koletnik@um.si. Alenka Valh Lopert, Univerza v Mariboru, Filozofska fakulteta, Maribor, Slovenija, e-pošta: alenka.valh@um.si. 


\section{Pregled in predstavitev aktualnih e-okolij}

V okviru projekta Slovenšcina na dlani smo pregledali vsa prostodostopna e-gradiva za pouk slovenščine $\mathrm{v}$ srednjih šolah (SŠ), in sicer:

Slovenščina za gimnazije in srednje šole:

- E-gradiva, slovenščina, Slovenščina za gimnazije in srednje šole: http://gradiva.txt.si/slovenscina/; 2. letnik: http://www.ssers.mb.edus.si/gradiva/w3/slo/000_mapa/index.html

- E-gradiva, slovenščina, Slovenščina za gimnazije in srednje šole: http://gradiva.txt.si/slovenscina/; 3. letnik: http://gradiva.txt.si/slovenscina/slovenscina-za-gimnazije-srednje-sole/3letnik/

- E-gradiva, slovenščina, Slovenščina za gimnazije in srednje šole: http://gradiva.txt.si/slovenscina/; 4. letnik:

http://gradiva.txt.si/slovenscina/slovenscina-za-gimnazije-srednje-sole/4letnik/

- E-gradiva, slovenščina: Slovenščina za triletne šole http://gradiva.txt.si/slovenscina/

E-učbeniki SIO.si:

- 1. letnik: http://eucbeniki.sio.si/slo1/index.html

Po pregledu in analizi e-gradiv glede na tipe nalog po $\mathrm{v}$ strokovni literaturi uveljavljeni klasifikaciji tipov nalog ugotavljamo, da je vsem pregledanim prosto dostopnim e-gradivom za pouk slovenščine v SŠ skupno to, da učencem in učiteljem ponujajo veliko število (raznovrstnih) nalog. Te se med seboj razlikujejo po tem, kako so sestavljene, glede na dejavnost učenca pri reševanju, glede na predvideni odgovor in po težavnosti oziroma taksonomski stopnji. Ugotavljamo tudi, da se v strokovni literaturi predstavljene klasifikacije tipov nalog razlikujejo po načinu razvrščanja. 
Slovenska psihologa Ivan Toličič in Leon Zorman sta naloge klasificirala in opisala $\mathrm{v}$ delu Testi znanja in njihova uporaba v praksi (1965). Razdelila sta jih $\mathrm{v}$ dve skupini $\mathrm{z}$ več podtipi, pri čemer sta kot kriterij delitve upoštevala sestavo nalog in način, kako učenci nanje odgovarjajo. $\mathrm{V}$ prvo skupino uvrščata naloge, pri katerih je treba odgovor zapisati, torej naloge, ki zahtevajo reprodukcijo učnega gradiva (naloge dopolnjevanja in naloge s kratkim odgovorom), $v$ drugo skupino pa naloge, pri katerih je treba odgovor izbrati (izbirni tip /s podtipi, tip povezovanja in urejanja ter alternativni tip /s podtipi) (Toličič, Zorman 1965: 26-57). Tamara Vomer v prispevku Pisno preverjanje in ocenjevanje pri pouku slovenskega jezilka v tretjem triletju osnovne šole (2008) naloge deli $\mathrm{v}$ dve skupini. $\mathrm{V}$ prvo uvršča naloge glede na raven razumevanja besedila, v drugo pa naloge glede na dejavnost učenca (Vomer 2008: $34,35)$.

Psihologinji Barica Marentič Požarnik in Cirila Peklaj (2002) sta v delu Preverjanje in ocenjevanje za uspešnejš študij naloge razvrstili v dve skupini. V prvo uvrščata t. i. esejske naloge, tj. naloge, pri katerih posameznik odgovarja prosto, $\mathrm{z}$ daljšim odgovorom, $\mathrm{v}$ drugo pa naloge objektivnega tipa, ki jih nadalje delita na naloge odprtega tipa in naloge zaprtega tipa (Marentič Požarnik, Peklaj 2002: 73-74, 87).

Maja Hadner v svoji magistrski nalogi (2017) ugotavlja, da nekaterim nalogam kljub omenjenim klasifikacijam ne moremo določiti tipa nalog. Zato je obstoječe klasifikacije nadgradila in naloge tipizirala glede na dejavnost, ki jo zahtevajo od posameznika. Nova, razširjena klasifikacija tako zajema enaindvajset tipov nalog, pri čemer so bili nekateri tipi nalog iz že obstoječih klasifikacij preimenovani (Hadner 2017: 25-33).

Iz vseh prostodostopnih e-gradiv za pouk slovenščine $\mathrm{v}$ srednjih šolah smo izpisali in prešteli posamezne tipe nalog, nato pa izračunali odstotni delež vseh tipov nalog $\mathrm{v}$ analiziranih gradivih. Za ponazoritev predstavljamo nabor nalog iz izbranih egradiv. $\mathrm{V}$ tabelah je predstavljen nabor nalog, ki $\mathrm{v}$ posameznem e-gradivu predstavljajo vsaj 70,0 \% vseh nalog. Naloge, ki predstavljajo manj kot 4,0 \% vseh nalog, $\mathrm{v}$ tabelah niso predstavljene. 
Tabela 1: Slovenščina: i-učbenik za slovenščino v 1. letniku gimnazij

\begin{tabular}{|l|c|c|}
\hline TIP NALOGE & ŠTEVILO NALOG & $\begin{array}{c}\text { ODSTOTNI } \\
\text { DELE } \check{~}\end{array}$ \\
\hline Naloga s kratkim odgovorom & 344 & $24,1 \%$ \\
\hline Naloga s prostim odgovorom & 241 & $16,9 \%$ \\
\hline $\begin{array}{l}\text { Izbirni tip naloge z enim pravilnim } \\
\text { odgovorom }\end{array}$ & 158 & $11,1 \%$ \\
\hline Naloga branja & 109 & $7,7 \%$ \\
\hline Alternativni tip naloge & 100 & $7,0 \%$ \\
\hline $\begin{array}{l}\text { Naloge, ki predvidevajo druge } \\
\text { dejavnosti v razredu }\end{array}$ & 74 & $5,2 \%$ \\
\hline Naloga $z$ ustnim odgovorom & 73 & $5,1 \%$ \\
\hline Naloga dopolnjevanja & 64 & $4,5 \%$ \\
\hline
\end{tabular}

http://eucbeniki.sio.si/slo1/index.html

Med 1430 nalogami najpogostejše naloge predstavljajo 81,6 \% vseh nalog, druge naloge se pojavljajo v 3,3\% ali manj.

Tabela 2: E-gradiva, slovenščina, Slovenščina za gimnazije in srednje šole

\begin{tabular}{|l|c|c|}
\hline TIP NALOGE & ŠTEVILO NALOG & $\begin{array}{c}\text { ODSTOTNI } \\
\text { DELE } \check{~}\end{array}$ \\
\hline Naloga s kratkim odgovorom & 194 & $24,2 \%$ \\
\hline $\begin{array}{l}\text { Izbirni tip naloge z enim pravilnim } \\
\text { odgovorom }\end{array}$ & 154 & $19,2 \%$ \\
\hline Naloga s prostim odgovorom & 108 & $13,5 \%$ \\
\hline Naloga vstavljanja & 54 & $6,7 \%$ \\
\hline Alternativni tip naloge & 44 & $5,5 \%$ \\
\hline Naloga dopolnjevanja & 42 & $5,2 \%$ \\
\hline
\end{tabular}

http://gradiva.txt.si/slovenscina/; 2. letnik: http://www.s-sers.mb.edus.si/gradiva/w3/slo/000_mapa/index.html 
Med 802 nalogama najpogostejše naloge predstavljajo 74,3\% vseh nalog, druge naloge se pojavljajo v 3,9\% ali manj.

Tabela 3: E-gradiva, slovenščina, Slovenščina za gimnazije in srednje šole

\begin{tabular}{|c|c|c|}
\hline TIP NALOGE & ŠTEVILO NALOG & ODSTOTNI DELEŽ \\
\hline $\begin{array}{l}\text { Naloga s kratkim } \\
\text { odgovorom }\end{array}$ & 107 & $24,9 \%$ \\
\hline $\begin{array}{l}\text { Izbirni tip naloge } z \text { enim } \\
\text { pravilnim odgovorom }\end{array}$ & 57 & $13,3 \%$ \\
\hline $\begin{array}{l}\text { Naloga, ki predvideva } \\
\text { uporabo drugih materialov }\end{array}$ & 55 & $12,8 \%$ \\
\hline $\begin{array}{l}\text { Naloga s prostim } \\
\text { odgovorom }\end{array}$ & 48 & $11,2 \%$ \\
\hline Alternativni tip naloge & 38 & $8,9 \%$ \\
\hline Naloga branja & 27 & $6,3 \%$ \\
\hline Naloga označevanja & 26 & $6,1 \%$ \\
\hline Naloga dopolnjevanja & 24 & $5,6 \%$ \\
\hline $\begin{array}{l}\text { Alternativni tip naloge } z \\
\text { utemeljitvijo }\end{array}$ & 18 & $4,2 \%$ \\
\hline
\end{tabular}

http://gradiva.txt.si/slovenscina/; 3. letnik: http://gradiva.txt.si/slovenscina/slovenscina-za-gimnazije-srednjesole/3-letnik/

Med 429 nalogami najpogostejše naloge predstavljajo 93,3\% vseh nalog, druge naloge se pojavljajo v 2,1 \% ali manj. 
Tabela 4: E-gradiva, slovenščina, Slovenščina za gimnazije in srednje šole

\begin{tabular}{|l|c|c|}
\hline TIP NALOGE & ŠTEVILO NALOG & ODSTOTNI DELEŽ \\
\hline $\begin{array}{l}\text { Naloga s kratkim } \\
\text { odgovorom }\end{array}$ & 129 & $36,7 \%$ \\
\hline $\begin{array}{l}\text { Naloga s prostim } \\
\text { odgovorom }\end{array}$ & 50 & $14,3 \%$ \\
\hline $\begin{array}{l}\text { Izbirni tip naloge z enim } \\
\text { pravilnim odgovorom }\end{array}$ & 36 & $10,3 \%$ \\
\hline $\begin{array}{l}\text { Naloga, ki predvideva } \\
\text { uporabo drugih } \\
\text { materialov }\end{array}$ & 32 & $9,1 \%$ \\
\hline Alternativni tip naloge & 27 & $7,7 \%$ \\
\hline Naloga branja & 16 & $4,6 \%$ \\
\hline Naloga dopolnjevanja & $24 \%$ \\
\hline
\end{tabular}

http://gradiva.txt.si/slovenscina/; 4. letnik: http://gradiva.txt.si/slovenscina/slovenscina-za-gimnazije-srednjesole/4-letnik/

Med 351 nalogami najpogostejše naloge predstavljajo 89,5 \% vseh nalog, druge naloge se pojavljajo v $3,7 \%$ ali manj. 
Tabela 5: E-gradiva, slovenščina: Slovenščina za triletne šole

\begin{tabular}{|l|c|c|}
\hline TIP NALOGE & ŠTEVILO NALOG & $\begin{array}{c}\text { ODSTOTNI } \\
\text { DELEŽ }\end{array}$ \\
\hline Naloga s kratkim odgovorom & 354 & $25,3 \%$ \\
\hline Alternativni tip naloge & 231 & $16,5 \%$ \\
\hline $\begin{array}{l}\text { Izbirni tip naloge z enim pravilnim } \\
\text { odgovorom }\end{array}$ & 194 & $13,9 \%$ \\
\hline Naloga dopolnjevanja & 79 & $5,6 \%$ \\
\hline Naloga branja & 78 & $5,5 \%$ \\
\hline Naloga z ustnim odgovorom & 65 & $4,7 \%$ \\
\hline $\begin{array}{l}\text { Naloga opazovanja } \\
\text { (ogled animacije posnetka) }\end{array}$ & 64 & $4,6 \%$ \\
\hline
\end{tabular}

http://gradiva.txt.si/slovenscina/

Med 1430 nalogami najpogostejše naloge predstavljajo 76,2\% vseh nalog, druge naloge se pojavljajo v 3,2\% ali manj.

Skupno število analiziranih tu predstavljenih nalog $\mathrm{v}$ srednješolskih e-gradivih je 4442. Z analizo smo želeli pridobiti podatke o zastopanosti posameznih tipov nalog v e-gradivih in rezultate primerjati s tipi nalog, ki so se pri pouku slovenščine izkazali kot najbolj priljubljeni. Na podlagi podatkov, pridobljenih s pomočjo ankete med učenci in učitelji, smo preverjali tudi aktualnost in funkcionalnost analiziranih eorodij.

\section{Interpretacija e-gradiv}

Podatki, ki smo jih pridobili, kažejo, da so tako med srednješolci kot med osnovnošolci najbolj priljubljeni naslednji tipi nalog: naloge izbirnega tipa (izbirni tip naloge z enim pravilnim odgovorom); alternativni tip naloge; naloge označevanja; naloge povezovanja; naloge urejanja; naloge, ki predvidevajo druge dejavnosti (kvizi, naloge, ki vključujejo video vsebino), najmanj priljubljene pa so naloge s kratkim odgovorom in naloge dopolnjevanja. Rezultati analize nalog tako v e-gradivih kot $\mathrm{v}$ učbeniških gradivih kažejo, da je najpogosteje zastopan tip nalog tisti, ki je pri 
učencih najmanj priljubljen, to je naloga s kratkim odgovorom. Tem nalogam v egradivih za 1 . in 4. letnik po pogostnosti pojavljanja sledijo naloge s prostim odgovorom, v e-gradivih za 2 . in 3. letnik izbirni tip naloge $\mathrm{z}$ enim pravilnim odgovorom, v e-gradivih za triletne šole pa alternativni tip naloge. Ob že omenjenih so med najpogostejšimi nalogami $v$ 1. letniku še naloge branja, naloge, ki predvidevajo druge dejavnosti $\mathrm{v}$ razredu, in naloge $\mathrm{z}$ ustnim odgovorom, $\mathrm{v} 2$. letniku naloge vstavljanja, $\mathrm{v} 3$. in 4 . letniku pa naloge, ki predvidevajo uporabo drugih materialov; v e-gradivih za triletne šole so med najpogostejšimi še naloge dopolnjevanja in branja.

Ker tipologija nalog obsega 21 različnih tipov nalog, bo v prihodnje pri pripravi eokolij smiselno razmišljati o bolj uravnoteženi zastopanosti vseh tipov nalog ter po možnosti tudi o izkazanem interesu učiteljev in učencev.

\section{Funkcionalnost e-okolij}

Vsi v projektu sodelujoči učitelji in učiteljice poznajo in uporabljajo obstoječa prostodostopna e- in i-gradiva za pouk slovenščine. Najpogosteje jih uporabljajo učitelji od 8. razreda OŠ do 4. letnika srednjih šol. Med prednostmi e- in i-gradiv učitelji izpostavljajo njihovo kakovost, prispevek k učinkovitejšemu pouku, lažje doseganje učnih ciljev, njihovo priljubljenost med dijaki, motiviranost dijakov za tovrstno delo, za katerega izkazujejo tudi dovolj visoko računalniško pismenost, njihovo metodološko in didaktično pestrost, raznolikost in privlačnost. Med slabostmi e- in i-gradiv izpostavljajo njihovo premajhno zahtevnost, še zlasti za gimnazijsko raven, neuravnoteženo zastopanost različnih tipov nalog, med katerimi prevladuje tip, ki je med učenci najmanj priljubljen, primanjkljaj video- in besedilnih gradiv, odsotnost hierarhične urejenosti gradiv po zahtevnosti, nezmožnost shranjevanja rešenih nalog, njihovo občasno nedostopnost, tehnične motnje in napake v gradivih (Šek Mertük 2018: 82-83).

Rezultati analize e-okolij izpostavljajo primanjkljaj naslednjih tipov nalog: nalog povezovanja, nalog vstavljanja, nalog označevanja, nalog popravljanja, nalog razvrščanja, nalog urejanja, nalog z dvema pravilnima odgovoroma, nalog z več pravilnimi odgovori, nalog $\mathrm{z}$ nepravilnim odgovorom in alternativnega tipa naloge $\mathrm{z}$ utemeljitvijo. Ker gre za tipe nalog, ki so še kako primerni za e-okolja, obenem pa omogočajo tudi uresničevanje in doseganje višjih taksonomskih stopenj (uporaba, 
analiza, sinteza), nam bodo tako rezultati analize kot opažanja učiteljev v pomoč pri zasnovi e-gradiv v okviru projekta.

\section{Literatura}

Maja HADNER, 2017: Pregled, primerjava in analiza delovnih zvezkov za pouk slovenskega jezika v srednjih šolah. Magistrsko delo. Maribor: Filozofska fakulteta, Oddelek za slovanske jezike in književnosti.

Barica MARENTIČ POŽARNIK, Cirila PEKLAJ, 2002: Preverjanje in ocenjevanje za uspešnejš študij. Ljubljana: Center za pedagoško izobraževanje Filozofske fakultete.

Simona PULKO, Melita ZEMLJAK JONTES, Mihaela KOLETNIK, Polonca ŠEK MERTÜK, Alenka VALH LOPERT, 2017: Analiza trenutno veljavnih e-okolij za poučevanje jezilkov (primarno eokolij za slovenš̌ino). Gradivo projekta Slovenščina na dlani. Maribor: Univerza v Mariboru.

Polonca ŠEK MERTÜK, 2017: Računalniška opremljenost sodelujočih šol in raba e-gradiv pri pouku slovenščine. Slovenščna na dlani 1. Ur. Natalija Ulčnik. Maribor: Univerzitetna založba Univerze v Mariboru. 81-84.

Ivan TOLIČIČ, Leon ZORMAN, 1965: Testi znanja in njïhova uporaba v praksi. Ljubljana: Zveza delavskih univerz Slovenije.

Tamara VOMER, 2008: Pisno preverjanje in ocenjevanje pri pouku slovenskega jezika v tretjem triletju osnovne šole. Preverjanje in ocenjevanje: specializirana strokovna pedagoška revija 5/2-3, 11-38. 


\title{
Izbor frazemov za bazo FRIDA
}

\author{
NATALIJA UlČNIK
}

\begin{abstract}
Povzetek V projektu Slovenšcina na dlani smo za natančnejšo slovarsko obravnavo izbrali sto frazemov. Pri tem smo izhajali iz seznamov, ki so v okviru projektnih aktivnosti nastali na podlagi zajemanja iz beril in obstoječih zbirk ter frazeološkega slovarja, vključene pa so bile tudi enote, za katere so učiteljice in učitelji s sodelujočih vzgojnoizobraževalnih zavodov ugotovili, da med učečimi se povzročajo pomenske nejasnosti. Kriteriji izbora so bili vezani na aktualnost enot, njihovo didaktično relevantnost, ustrezno frekventnost $\mathrm{v}$ rabi in pokrivanje različnih tematskih skupin. $\mathrm{V}$ naslednji projektni fazi je načrtovana natančna analiza izbranih enot in njihov slovarski opis.
\end{abstract}

Ključne besede: $\cdot$ Slovenščina na dlani $\bullet$ frazem $\bullet$ baza podatkov $\bullet$ slovarski opis $\bullet$ tematske skupine $\bullet$

NASLOV AVTORICE: Natalija Ulčnik, Univerza v Mariboru, Filozofska fakulteta, Maribor, Slovenija, epošta: natalija.ulcnik@um.si. 


\section{Uvod}

Eden izmed sklopov učnega e-okolja Slovenščna na dlani, ki nastaja med letoma 2017 in 2021, bo vezan na frazeologijo. Ob nalogah in razlagah temeljnih frazeoloških pojmov bo uporabnikom v bazi, ki smo jo poimenovali FRIDA (FRazemi In pregovori na DlAni), na voljo tudi slovarski opis izbranih frazemov. Ta bo namenjen podrobnejšemu seznanjanju s konkretnimi frazemi, obenem pa bo služil tudi kot zgled za pripravo samostojnih slovarskih opisov še neopisanih enot.

\section{Kriteriji za izbor frazemov}

Osnovni kriterij za izbor frazemov je bila njihova aktualnost. Ker pa za slovenščino ne obstaja seznam najbolj aktualnih frazemov, je bilo treba natančneje določiti kriterije izbora. V prvi fazi smo pregledali učbeniška gradiva, zlasti berila za osnovno in srednjo šolo, in preverjali prisotnost frazemov $v$ njih. Natančneje so bila pregledana naslednja berila:

- Berta GOLOB idr., 2008: Kdo se skriva v ogledalu? Berilo 6: za šesti razred osnovne šole. 2., prenovljena izdaja. Ur. Alenka Kepic Mohar. Ljubljana: Založba Mladinska knjiga.

- Miha MOHOR idr., 2010: Sréra se mi v pesmi smeje. Berilo 7: za sedmi razred osnovne šle. Ljubljana: Mladinska knjiga.

- Mojca HONZAK idr., 2000: Dober dan, zivljenje. Berilo za sedmi razred osemletne in osmi razred devetletne osnoune šole. Ljubljana: Mladinska knjiga.

- Mojca HONZAK idr., 2005: Skrivno življenje besed. Berilo za deveti razred osnovne šle. Ljubljana: Mladinska knjiga.

- Darinka AMBROŽ idr., 2005: Branja 1. Berilo in ućbenik za 1. letnik gimnazij ter stiriletnih strokovnih šol. Ljubljana: DZS.

- Vinko CUDERMAN idr., 2003: Branja 2. Berilo in učbenik za 2. letnik gimnazij ter štiriletnih strokovnih šol. Ljubljana: DZS.

- Darinka AMBROŽ idr., 2005: Branja 4. Berilo in učbenik za 4. letnik gimnazij ter štiriletnih strokovnih šol. Ljubljana: DZS. 
Izhajali smo tudi iz obstoječega večjezičnega frazeološkega učnega gradiva (Ephras) in frazeološkega slovarja Janeza Kebra (spletna izdaja je iz leta 2015 in je dostopna na portalu Fran). Z ročnim izpisovanjem in avtomatskim zajemanjem smo dobili širok nabor enot, ki smo jim določili frekvenco pojavljanja v korpusih. ${ }^{1}$ Ko je bila znana aktualnost enot $\mathrm{v}$ sodobnih pisnih besedilih, smo frazeme presojali še z vidika njihove didaktične relevantnosti. Pri tem je bila v ospredju predpostavka o oteženem razumevanju enot $z$ izkazano večjo stopnjo idiomatičnosti, upoštevali pa smo tudi konkretne predloge učiteljev in učiteljic, ki so na podlagi svojih praktičnih izkušenj izpostavili med učenci in dijaki slabše poznane enote in enote, pri katerih je bilo opaženo pomanjkljivo razumevanje pomena (npr. gordijski vožl, priti z dešja pod kap). Upoštevali smo tudi osnovno zamisel pokrivanja različnih tematskih skupin (npr. človek, odnosi, predmetnost, čas in prostor) ter dodali posamezne enote, ki so tipične za slovenski govorni prostor in obenem izkazujejo zadostno frekventnost rabe (npr. vlěri dreto).

\section{Kategorizacija izbranih frazemov po tematskih skupinah}

Izbrane frazeme smo kategorizirali po tematskih skupinah, saj izhajamo iz realnih okoliščin rabe (npr. kako lahko frazeološko izrazim ljubezen in druge medosebne odnose, katere frazeme lahko uporabim, ko govorim o času, s katerimi frazemi lahko opišem neko predmetnost).

Sprva je bilo določenih 10 tematskih skupin, ki smo jih še dodatno členili na posamezne podskupine. Za končno klasifikacijo smo izbrali 6 tematskih skupin, in sicer: 1. Človek, 2. Odnosi, 3. Dejavnost in bivanje, 4. Predmetnost in pojavnost, 5. Čas in prostor, 6. Količina, mera, stopnja (Ulčnik, Jesenšek, Meterc 2019). Vsako tematsko skupino smo zapolnili z izbranimi frazemi.

V nadaljevanju je 100 frazemov prikazanih po posameznih tematskih skupinah. Prve štiri skupine so z vidika zajetih frazemov obsežnejše in vsebujejo po 20 frazemov, zadnji dve skupini vsebujeta po 10 frazemov (skupaj 100 frazemov). Posamezne enote bo na podlagi pomenske analize mogoče umestiti $\mathrm{v}$ več tematskih skupin. $\mathrm{V}$ nadaljevanju je prikazana kategorizacija enot.

\footnotetext{
${ }^{1}$ Izbrali smo naslednje korpuse: Gigafida v. 2.0 Dedup, KAS (akademska besedila), slWac (Slovene Web), Janes (družbena omrežja).
} 


\section{ČLOVEK (videz, značaj, čustva, počutje ...)}

\begin{tabular}{|l|l|}
\hline biti (si) podoben kot jajce jajcu & sedeti na dveh stolih \\
\hline biti kot noč in dan & riniti z glavo skozi zid \\
\hline tiha voda & imeti v krvi kaj \\
\hline črna ovca & kaj je pisano na kožo komu \\
\hline Ahilova peta & imeti maslo na glavi \\
\hline stisniti zobe & iskati dlako v jajcu \\
\hline tiščati glavo v pesek & biti krvav pod kožo \\
\hline vreči puško v koruzo & delati iz muhe slona \\
\hline debelo gledati & imeti v malem prstu kaj \\
\hline biti brez dlake na jeziku & posuti se s pepelom \\
\hline
\end{tabular}

ODNOSI (sporazumevanje, družina, prijatelji, odnos do drugih ...)

\begin{tabular}{|l|l|}
\hline brati med vrsticami & pustiti na cedilu koga \\
\hline imeti dolg jezik & biti kot pes in mačka \\
\hline narediti medvedjo uslugo komu & biti desna roka \\
\hline zakopati bojno sekiro & mlatiti prazno slamo \\
\hline pogledati skozi prste komu & metati polena pod noge komu \\
\hline pomesti pred svojim pragom & metati pesek v oči komu \\
\hline dihati za ovratnik komu & vleči za nos koga \\
\hline soliti pamet komu & držati figo v žepu \\
\hline vrniti milo za drago & kaj gre v nos komu \\
\hline iti na roko komu & pihati na dušo komu \\
\hline
\end{tabular}


DEJAVNOST IN BIVANJE (šolanje, delo, ustvarjanje, delovanje, šport ...)

\begin{tabular}{|l|l|}
\hline dobiti zeleno luč & z roko $\mathrm{v}$ roki \\
\hline ločiti zrnje od plev & zatresti mrežo \\
\hline pljuniti v roke & doživeti hladen tuš \\
\hline Sizifovo delo & zadeti žebljico na glavico \\
\hline z levo roko & pomesti pod preprogo \\
\hline priti na svoj račun & kaj pade v vodo \\
\hline boj z mlini na veter & kaj gre kot po maslu \\
\hline pljuvati v lastno skledo & udariti po žepu koga \\
\hline priti z dežja pod kap & stopiti na prste komu \\
\hline sekira pade v med komu & vleči dreto \\
\hline
\end{tabular}

PREDMETNOST IN POJAVNOST (značilnosti predmetov, pojavov, dogodkov ...)

\begin{tabular}{|l|l|}
\hline kaj je (kot) na dlani & rasti kot gobe po dežju \\
\hline drag kot žafran & $k a j$ visi na nitki \\
\hline kaj je iz trte izvit & labodji spev \\
\hline lanski sneg & gordijski vozel \\
\hline jabolko spora & Pandorina skrinjica \\
\hline mačji kašelj & Tantalove muke \\
\hline mala malica & kamen spotike \\
\hline španska vas & dvorezen meč \\
\hline zavit v meglo & trd oreh \\
\hline lije kot iz škafa & za lase privlečen \\
\hline
\end{tabular}

\section{ČAS IN PROSTOR}

\begin{tabular}{|l|l|}
\hline na vrat na nos & kajje pred vrati \\
\hline kot strela z jasnega & čez drn in strn \\
\hline na prvo žogo & bogu za hrbtom \\
\hline pet minut pred dvanajsto & biti za petami komu \\
\hline voda teče v grlo komu & na vsake kvatre \\
\hline
\end{tabular}




\section{KOLIČINA, MERA, STOPNJA}

\begin{tabular}{|l|l|}
\hline kaplja v morje & bela vrana \\
\hline kot listja in trave & kaj poka po šivih \\
\hline levji delě̌ & na celi črti \\
\hline od a do ž & z veliko žlico \\
\hline čez palec & kot za stavo \\
\hline
\end{tabular}

Za izbranih 100 enot smo izdelali geslovnik:

\begin{tabular}{|c|c|}
\hline 1. & Ahilova peta \\
\hline 2. & bela vrana \\
\hline 3. & biti (si) podoben kot jajce jajcu \\
\hline 4. & biti brez dlake na jeziku \\
\hline 5. & biti desna roka \\
\hline 6. & biti kot noč in dan \\
\hline 7. & biti kot pes in mačka \\
\hline 8. & biti krvav pod kožo \\
\hline 9. & biti za petami komu \\
\hline 10. & bogu za hrbtom \\
\hline 11. & boj z mlini na veter \\
\hline 12. & brati med vrsticami \\
\hline 13. & čez drn in strn \\
\hline 14. & čez palec \\
\hline 15. & črna ovca \\
\hline 16. & debelo gledati \\
\hline 17. & delati iz muhe slona \\
\hline 18. & dihati za ovratnik komu \\
\hline 19. & dobiti zeleno luč \\
\hline 20. & doživeti hladen tuš \\
\hline 21. & drag kot žafran \\
\hline 22. & držati figo v žepu \\
\hline 23. & dvorezen meč \\
\hline 24. & gordijski vozel \\
\hline 25. & imeti dolg jezik \\
\hline 26. & imeti maslo na glavi \\
\hline
\end{tabular}


27. imeti v krvi kaj

28. imetiv malem prstu kaj

29. iskati dlako $\mathrm{v}$ jajcu

30. iti na roko komu

31. jabolko spora

32. kaj gre kot po maslu

33. kaj gre v nos komu

34. kaj je iz trte izvito

35. kaj je kot na dlani

36. kaj je pisano na kožo komu

37. kaj je pred vrati

38. kaj poka po šivih

39. kaj pade $\mathrm{v}$ vodo

40. kaj visi na nitki

41. kamen spotike

42. kaplja v morje

43. kot listja in trave

44. kot strela $\mathrm{z}$ jasnega

45. kot za stavo

46. labodji spev

47. lanski sneg

48. levji delež

49. lije kot iz škafa

50. ločiti zrnje od plev

51. mačji kašelj

52. mala malica

53. metati pesek v oči komu

54. metati polena pod noge komu

55. mlatiti prazno slamo

56. na celi črti

57. na prvo žogo

58. na vrat na nos

59. na vsake kvatre

60. narediti medvedjo uslugo kоти

61. od a do ž

62. Pandorina skrinjica

63. pet minut pred dvanajsto 
64. pihati na dušo komu

65. pljunitiv roke

66. pljuvati v lastno skledo

67. pogledati skozi prste komu

68. pomesti pod preprogo

69. pomesti pred svojim pragom

70. posuti se s pepelom

71. priti na svoj račun

72. priti $z$ dežja pod kap

73. pustiti na cedilu koga

74. rasti kot gobe po dežju

75. riniti $z$ glavo skozi zid

76. sedeti na dveh stolih

77. sekira pade $\mathrm{v}$ med komu

78. Sizifovo delo

79. soliti pamet komu

$80 . \quad$ stisniti zobe

81. stopiti na prste komu

82. španska vas

83. Tantalove muke

84. tiha voda

85. tiščati glavo $\mathrm{v}$ pesek

86. $\quad$ trd oreh

87. udariti po žepu koga

88. vleči dreto

89. vleči za nos koga

90. voda teče $\mathrm{v}$ grlo komu

91. vreči puško $\mathrm{v}$ koruzo

92. vrniti milo za drago

93. $\quad z$ levo roko

94. $\quad z$ roko $v$ roki

95. z veliko žlico

96. za lase privlečen

97. zadeti žebljico na glavico

98. zakopati bojno sekiro

99. zatresti mrežo

100. zavit $\mathrm{v}$ meglo 
Frazemi so $\mathrm{v}$ geslovniku zapisani $\mathrm{v}$ slovarski obliki (delno že z nakazano fakultativnostjo sestavin), pri posameznih enotah pa bo šele natančnejša analiza omogočila določitev izhodiščne oblike (pri teh enotah dopuščamo možnost kasnejše spremembe, npr. biti kot pes in mačka - gledati se kot pes in mackea; posuti se s pepelomposipati se s pepelom).

\section{Načrtovanje nadaljnjih projektnih aktivnosti}

Vse enote bodo $\mathrm{v}$ naslednji projektni fazi natančno slovarsko opisane, pri tem pa bomo upoštevali: 1. oblikovne in tipološke lastnosti frazeološke enote, 2. pomenske in pragmatične lastnosti ter 3. slovnične lastnosti. Dodani bodo tudi relevantni zgledi rabe.

$\mathrm{Na}$ frazeološke enote in njihove opise bodo v učnem e-okolju vezane tudi naloge, katerih osnovni namen je doseči, da bodo uporabniki frazeme prepoznavali (na oblikovni ravni, v besedilu), znali ločevati frazeme od pregovorov, prepoznavali medfrazemska razmerja (so- in protipomenskost), razumeli pomen frazemov, jih znali pomensko pojasniti ter nadomestiti z nevtralnim izražanjem oz. nevtralno izražanje nadomestiti s frazeološkim, da bodo frazeme znali ustrezno, smiselno in tudi kreativno uporabljati ter na najvišji taksonomski ravni tudi uporabiti pridobljeno znanje pri samostojni pripravi slovarskih sestavkov. Obenem želimo, da bi učno eokolje s primerno zastavljenimi izzivi uporabnike spodbudilo tudi $\mathrm{k}$ nadaljnjemu (raziskovalnemu, kreativnemu) ukvarjanju s frazeologijo.

\section{Literatura}

Natalija ULČNIK, Vida JESENŠEK, Matej METERC, 2019: 2.4.2 Izdelava seznama frazemov in pregovorov. Gradivo projekta Slovenšcina na dlani. Maribor: Filozofska fakulteta. 


\title{
Izbor pregovorov za bazo FRIDA
}

\author{
NATAlija UlČnik in MATEj Meterc
}

Povzetek Baza FRIDA, ki je del učnega e-okolja Slovenšcina na dlani, se nanaša na frazeme in pregovore (FRazemi In pregovori na DlAni). V njej bodo uporabnikom na voljo naloge, vezane na frazeologijo, dostopne pa bodo tudi razlage frazeoloških pojmov (npr. kaj je pregovor, kakšna je razlika med pregovorom in rekom, kaj je antipregovor) ter slovarski opisi za izbranih sto pregovorov. V članku so predstavljeni kriteriji za izbor enot in njihova kategorizacija.

Ključne besede: $\bullet$ Slovenččina na dlani $\bullet$ pregovor $\bullet$ baza podatkov $\bullet$ slovarski opis • tematske skupine •

NASLOVA AVTORJEV: Natalija Ulčnik, Univerza v Mariboru, Filozofska fakulteta, Maribor, Slovenija, epošta: natalija.ulcnik@um.si. Matej Meterc, ZRC SAZU, Inštitut za slovenski jezik Frana Ramovša, Ljubljana, Slovenija, matej.meterc@zrc-sazu.si. 


\section{Uvod}

V okviru projekta Slovenščna na dlani pripravljamo podrobnejše slovarske opise izbranih frazemov in pregovorov. Odločili smo se za izbor 100 frazemov in 100 pregovorov, torej skupno 200 enot. Ker gre za zelo omejen nabor, je bilo treba v izhodišču premisliti o kriterijih za izbor.

\section{Izbor enot}

S pregovori in sorodnimi žanri se ukvarja paremiologija (prim. Meterc 2018). Paremiologi, strokovnjaki za to področje, so že v preteklosti na podlagi anket pripravljali različne sezname, $\mathrm{v}$ katere so zajemali pregovore in njim sorodne enote, ki so med govorci najbolj poznane - gre za t. i. paremiološki minimum. Nekateri tovrstni seznami so bili dopolnjeni tudi s podatkom o pogostosti teh enot v rabi, kar imenujemo paremiološki optimum. Oba seznama danes obstajata tudi za slovenščino (prim. Ďurčo, Meterc 2013: 23-25; Meterc 2017).

Pri izboru enot za bazo FRIDA smo izhajali iz paremiološkega optimuma, ki vsebuje 300 enot. Gre za enote, ki jih pozna več kot 79 \% vprašanih in so obenem zelo pogoste $\mathrm{v}$ rabi. Slednje je bilo preverjano s korpusno analizo s sistematičnim iskanjem osnovne oblike različnih variant iste paremiološke enote. S tega seznama so bile najprej izločene enote, ki niso pregovori, npr. reki (rě̌eno - storjeno, mi o volku, volk iz gozda), pri čemer smo se ravnali po Mlackovem razlikovanju (Mlacek 1983: 131) med enotami $z$ naukom, vodilom (pregovori) od enot, ki zgolj slikovito opisujejo tipsko situacijo (reki). V naslednji fazi so bile upoštevane tematske skupine, ki smo jih upoštevali za celotno bazo FRIDA, torej tudi za besednozvezne frazeme. Pri zapolnjevanju posameznih skupin se je pokazal primanjkljaj enot, ki bi bile pomensko vezane na posamezno temo, npr. šport (žoga je okrogla), zato smo se odločili skupine smiselno povezati. Dobili smo končen seznam tematskih skupin, ki smo jih nato zapolnili s pregovori. V veliki večini smo tako v nabor 100 pregovorov vključili enote iz paremiološkega optimuma, pogostnost tistih enot, ki smo jih poiskali izven njega, pa smo prav tako preverili v korpusu in sodijo med dovolj pogoste in s tem reprezentativne slovenske pregovore. 


\section{Kategorizacija izbranih frazemov}

$V$ nadaljevanju je prikazan izbor enot za 6 temeljnih tematskih skupin, in sicer: 1 . Človek, 2. Odnosi, 3. Dejavnost in bivanje, 4. Predmetnost in pojavnost, 5. Čas in prostor, 6. Količina, mera, stopnja. Razporeditev pregovorov je sledila načelu, da en pregovor lahko opisuje široko množico sorodnih situacij oziroma da so pregovori po naravi heterosituativne in polifunkcionalne enote. Prav zato je veliko izmed 100 pregovorov lahko razvrščenih v več tematskih skupin hkrati (prim. Ulčnik, Jesenšek, Meterc 2019).

\section{ČLOVEK (videz, značaj, čustva, počutje ...)}

\begin{tabular}{|l|l|}
\hline jabolko ne pade daleč od drevesa & kdor visoko leta, nizko pade \\
\hline tiha voda bregove dere & osel gre samo enkrat na led \\
\hline videz vara & na jeziku med, v srcu led \\
\hline vsi smo krvavi pod kožo & oči so ogledalo duše \\
\hline skromnost je lepa čednost & navada je železna srajca \\
\hline previdnost je mati modrosti & zarečenega kruha se največ poje \\
\hline dobrota je sirota & laž ima kratke noge \\
\hline vsak je svoje sreče kovač & po vsakem dežju posije sonce \\
\hline jabolko ne pade daleč od drevesa & kdor visoko leta, nizko pade \\
\hline tiha voda bregove dere & \\
\hline
\end{tabular}


ODNOSI (sporazumevanje, družina, prijatelji, odnos do drugih ...)

\begin{tabular}{|l|l|}
\hline človek človeku volk & beseda ni konj \\
\hline v slogi je moč & kri ni voda \\
\hline prijatelja spoznaš v nesreči & nasprotja se privlačijo \\
\hline $\begin{array}{l}\text { povej mi, s kom se družiš, in povem ti, } \\
\text { kdo si }\end{array}$ & molk je zlato \\
\hline na jeziku med, v srcu led & čisti računi, dobri prijatelji \\
\hline ti očeta do praga, sin tebe čez prag & kadar mačke ni doma, miši plešejo \\
\hline vrana vrani ne izkljuje oči & obljuba dela dolg \\
\hline $\begin{array}{l}\text { kdor drugemu jamo koplje, sam vanjo } \\
\text { pade }\end{array}$ & roka roko umije \\
\hline lepa beseda lepo mesto najde & kjer se prepirata dva, tretji dobiček ima \\
\hline ljubezen je slepa & služba je služba, družba pa družba \\
\hline žlahta - raztrgana plahta & greh se pove, grešnika pa ne \\
\hline
\end{tabular}

DEJAVNOST IN BIVANJE (šolanje, delo, ustvarjanje, delovanje, šport ...)

\begin{tabular}{|l|l|}
\hline brez dela ni jela & eno je reči, drugo storiti \\
\hline vaja dela mojstra & kovačeva kobila je vedno bosa \\
\hline vsaka šola nekaj stane & poskusiti ni greh \\
\hline kakor si boš postlal, tako boš spal & denar je sveta vladar \\
\hline kar seješ, to žanješ & v sili še hudič muhe žre \\
\hline vsak začetek je težak & $\begin{array}{l}\text { zrno do zrna pogača, kamen na kamen } \\
\text { palača }\end{array}$ \\
\hline brez muje se še čevelj ne obuje & $\begin{array}{l}\text { nobena juha se ne poje tako vroča, kot } \\
\text { se skuha }\end{array}$ \\
\hline v tretje gre rado & vsak izgovor je dober \\
\hline na napakah se učimo & motiti se je človeško \\
\hline sreča spremlja hrabre & \\
\hline
\end{tabular}


PREDMETNOST IN POJAVNOST (značilnosti predmetov, pojavov, dogodkov ...)

\begin{tabular}{|l|l|}
\hline ni vse zlato, kar se sveti & dober glas seže v deveto vas \\
\hline podarjenemu konju se ne gleda v zobe & dobro blago se samo hvali \\
\hline drugi kraji, drugi običaji & ne hvali dneva pred večerom \\
\hline mladost je norost & tiha voda bregove dere \\
\hline na jeziku med, v srcu led & videz vara \\
\hline vsake oči imajo svojega malarja & bolje vrabec v roki kot golob na strehi \\
\hline prepovedan sadež je najslajši & strah je votel, okrog ga pa nič ni \\
\hline riba pri glavi smrdi & tudi slepa kura zrno najde \\
\hline gliha vkup štriha & žoga je okrogla \\
\hline spanec je boljši kot žganec & lakota je najboljši kuhar \\
\hline
\end{tabular}

\section{ČAS IN PROSTOR}

\begin{tabular}{|l|l|}
\hline rana ura, zlata ura & ljubo doma, kdor ga ima \\
\hline bolje pozno kot nikoli & vse poti vodijo v Rim \\
\hline nikoli ni prepozno & drugi kraji, drugi običaji \\
\hline kuj železo, dokler je vroče & hiti počasi \\
\hline $\begin{array}{l}\text { priložnost zamujena, ne vrne se } \\
\text { nobena }\end{array}$ & kdor čaka, dočaka \\
\hline po toči zvoniti je prepozno & počasi se daleč pride \\
\hline kdor prej pride, prej melje & daleč od oči, daleč od srca \\
\hline čas celi vse rane & \\
\hline
\end{tabular}

\section{KOLIČINA, MERA, STOPNJA}

\begin{tabular}{|l|l|}
\hline iz malega raste veliko & ko ima hudič mlade, jih ima veliko \\
\hline ena lastovka še ne prinese pomladi & vse ima svoje meje \\
\hline več glav več ve & eden ni nobeden \\
\hline bolje nekaj kot nič & veliko grmenja, malo dežja \\
\hline manj je več & številke ne lažejo \\
\hline
\end{tabular}


Na koncu je bil za izbranih 100 pregovorov izdelan še geslovnik.

1. beseda ni konj

2. bolje nekaj kot nič

3. bolje pozno kot nikoli

4. bolje vrabec $\mathrm{v}$ roki kot golob na strehi

5. brez dela ni jela

6. brez muje se še čevelj ne obuje

7. čas celi vse rane

8. $\quad$ čisti računi, dobri prijatelji

9. človek človeku volk

10. človek ne živi samo od kruha

11. daleč od oči, daleč od srca

12. denar je sveta vladar

13. dober glas seže $\mathrm{v}$ deveto vas

14. dobro blago se samo hvali

15. dobrota je sirota

16. drugi kraji, drugi običaji

17. eden ni nobeden

18. ena lastovka še ne prinese pomladi

19. eno je reči, drugo storiti

20. gliha vkup štriha

21. greh se pove, grešnika pa ne

22. hiti počasi

23. iz malega raste veliko

24. jabolko ne pade daleč od drevesa

25. kadar mačke ni doma, miši plešejo

26. kakor si boš postlal, tako boš spal

27. kar seješ, to žanješ

28. kdor čaka, dočaka

29. kdor drugemu jamo koplje, sam vanjo pade

30. kdor prej pride, prej melje

31. kdor visoko leta, nizko pade

32. kjer se prepirata dva, tretji dobiček ima

33. ko ima hudič mlade, jih ima veliko

34. kovačeva kobila je vedno bosa

35. kri ni voda 
36. kuj železo, dokler je vroče

37. lakota je najboljši kuhar

38. lastna hvala, cena mala

39. laž ima kratke noge

40. lepa beseda lepo mesto najde

41. ljubezen je slepa

42. ljubo doma, kdor ga ima

43. manj je več

44. mladost je norost

45. molk je zlato

46. motiti se je človeško

47. na jeziku med, v srcu led

48. na napakah se učimo

49. nasprotja se privlačijo

50. navada je železna srajca

51. ne hvali dneva pred večerom

52. ni vse zlato, kar se sveti

53. nikoli ni prepozno

54. nobena juha se ne poje tako vroča, kot se skuha

55. obljuba dela dolg

56. oči so ogledalo duše

57. osel gre samo enkrat na led

58. po toči zvoniti je prepozno

59. po vsakem dežju posije sonce

60. počasi se daleč pride

61. podarjenemu konju se ne gleda $\mathrm{v}$ zobe

62. poskusiti ni greh

63. povej mi, s kom se družiš, in povem ti, kdo si

64. prepovedan sadež je najslajši

65. previdnost je mati modrosti

66. prijatelja spoznaš v nesreči

67. priložnost zamujena, ne vrne se nobena

68. rana ura, zlata ura

69. riba smrdi pri glavi

70. roka roko umije

71. skromnost je lepa čednost

72. služba je služba, družba pa družba 
73. spanec je boljši kot žganec

74. sreča spremlja hrabre

75. strah je votel, okrog ga pa nič ni

76. številke ne lažejo

77. ti očeta do praga, sin tebe čez prag

78. tiha voda bregove dere

79. tudi slepa kura zrno najde

80. V sili še hudič muhe žre

81. v slogi je moč

82. $\quad \mathrm{v}$ tretje gre rado

83. vaja dela mojstra

84. več glav več ve

85. veliko grmenja, malo dežja

86. videz vara

87. vrana vrani ne izkljuje oči

88. vsak izgovor je dober

89. vsak je svoje sreče kovač

90. vsak začetek je težak

91. vsaka šola nekaj stane

92. vsaka vas ima svoj glas

93. vsake oči imajo svojega malarja

94. vse ima svoje meje

95. vse poti vodijo v Rim

96. $\quad$ vsi smo krvavi pod kožo

97. zarečenega kruha se največ poje

98. zrno do zrna pogača, kamen na kamen palača

99. Žlahta - raztrgana plahta

100. žoga je okrogla

\section{Sklep}

Izbrane enote bodo $\mathrm{v}$ naslednji projektni fazi na različnih ravneh natančno analizirane (oblikovna raven, pomen, raba) in predstavljene $\mathrm{v}$ obliki slovarskih opisov. Ti bodo približani primarnim uporabnikom učnega e-okolja Slovenšcina na dlani, torej osnovno- in srednješolcem. Četudi gre za zelo omejen izbor enot, bodo ti opisi lahko služili tudi kot zgled za pripravo samostojnih slovarskih opisov v okviru nalog s področja frazeologije. Upamo tudi, da bomo s pomočjo baze FRIDA med 
uporabniki vzbudili zanimanje za nadaljnje ukvarjanje z bogatim paremiološkim gradivom.

\section{Literatura}

Peter ĎURČO, Matej METERC, 2013: Empirične paremiološke raziskave tipov ekvivalentnosti in suprasemantičnih razlik v slovenščini in slovaščini. Slavia Centralis 6/2, 20-36. Dostopno 20. 5. 2019 na: https://kuscholarworks.ku.edu/bitstream/handle/1808/12919/02_SCN_2_2013_Durco_M eterc.pdf;jsessionid $=$ F1EB72C8532AB590BFEEB5F466E24453? sequence $=1$

Matej METERC, 2017: Paremiološki optimum: Najbolj poznani in pogosti pregovori ter sorodne paremije $v$ slovenščni. Ljubljana: Založba ZRC. ZRC SAZU.

Matej METERC, 2018: O pregovorih in njihovem raziskovanju. Slovenščina na dlani 1. Ur. Natalija Ulčnik. Maribor.

Jozef MLACEK, 1983: Problémy komplexného rozboru prísloví a porekadiel. Slovenská reč 48/2, 129_ 140.

Natalija ULČNIK, Vida JESENŠEK, Matej METERC, 2019: 2.4.2 Izdelava seznama frazemov in pregovorov. Gradivo projekta Slovenšcina na dlani. Maribor: Filozofska fakulteta. 


\title{
Razvijanje funkcionalne pismenosti prek besedil zbirke BERTA
}

\begin{abstract}
MIRA KRAJNC IVIČ IN INES VORŠIČ
Povzetek E-okolje, ki nastaja v okviru projekta Slovenščina na dlani, se osredotoča tudi na rabo besedil. Učencem, dijakom in drugim uporabnikom želi ponuditi možnost, da izpopolnjujejo svoje znanje o besedilih. Namen pričujočega prispevka je seznaniti bralce $z$ dosedanjimi aktivnostmi na področju zbiranja besedil in oblikovanja besedilnega korpusa BERTA, ki bo služil pripravi nalog za razvijanje in poglabljanje funkcionalne oziroma bralne pismenosti. $\mathrm{V}$ prispevku predstavljamo cilje in znanja, ki jih bodo uporabniki besedilnega korpusa lahko usvojili, ter tipe vaj in nalog, s pomočjo katerih bo uporabnik učnega e-okolja spoznaval, pridobival, utrjeval in vrednotil zmožnosti za tvorjenje in interpretiranje besedil.
\end{abstract}

Ključne besede: • besedilni korpus $\bullet$ besedilo $\bullet$ besedilne skupine • BERTA • funkcionalna/bralna pismenost •

\footnotetext{
NASLOVA AVTORIC: Mira Krajnc Ivič, Univerza v Mariboru, Filozofska fakulteta, Maribor, Slovenija, epošta: mira.krajnc@um.si. Ines Voršič, Univerza v Mariboru, Filozofska fakulteta, Maribor, Slovenija, e-pošta: ines.vorsic@um.si.
} 


\section{Uvod}

Sporazumevanje v maternem jeziku je po Priporočilu Evropskega sveta in Evropskega parlamenta temelj za smiselno povezovanje vseh ostalih sedmih ključnih kompetenc. Opredeljeno je kot »sposobnost izražanja in razumevanja pojmov, misli, čustev, dejstev in mnenj $\mathrm{v}$ pisni in ustni obliki /.../ ter na ustrezen in ustvarjalen način jezikovno medsebojno delovanje $\mathrm{v}$ vseh družbenih in kulturnih okoliščinah izobraževanje in usposabljanje, delo, dom in prosti čas« (2006: 14). Znotraj slovenističnega jezikoslovja je razvoj pojmovanja in poimenovanja jezikovne sporazumevalne zmožnosti predstavila Marja Bešter (2011). Po Bachmanu in Palmerju povzema model sporazumevalne jezikovne zmožnosti, ki jo sestavljata strateška zmožnost in jezikovno znanje (jezikovna zmožnost). Prva je zmožnost odločanja, izbiranja, načrtovanja o komunikacijskih ciljih ter o načinu uporabe jezikovnega znanja, ki ga sestavljata dve vrsti znanja: a) organizacijsko in b) pragmatično znanje. Po mnenju Jerce Vogel (2014: 12) šele model kritične sporazumevalne/jezikovne/ zmožnosti omogoča posamezniku, da z razvijanjem kritičnega mišljenja samoiniciativno in neodvisno deluje v družbenem, političnem in kulturnem kontekstu. To po njenem pomeni, »da se sporazumevanje in širše jezikovno delovanje ne obravnavata več kot zgolj kognitivna spretnost in veščina, temveč kot kulturna in družbena praksa, ki ima vsaj toliko kot s kodom in veščinami opraviti z ideologijami, identitetami in vrednotami« (Vogel 2014: 12). Avtorica tako jasno povezuje jezikovno znanje (pravopisno, pravorečno, slovnično, slovarsko in besedilno) z družbeno-kulturnimi danostmi oziroma značilnostmi organizacije nekega družbenega sistema določene skupnosti. Ključnega pomena za kritično jezikovno sporazumevalno zmožnost v določenem jeziku je sposobnost za ustrezno sprejemanje oziroma razumevanje in tvorjenje besedil. Z ozirom na to je e-orodje Slovenšrina na dlani $\mathrm{v}$ posebnem sklopu (Iz malega zraste veliko) namenjeno nalogam in vajam s področja besedil in njihove rabe. $\mathrm{V}$ prispevku bodo predstavljeni rezultati aktivnosti skupine za pripravo vaj in nalog na področju besedil. Te aktivnosti so vezane na zbiranje gradiva za izdelavo zbirke BERTA (projektne aktivnosti 2.3.2 Izdelava pisnega podkorpusa in 2.3.3 Izdelava govornega podkorpusa), učne cilje in predvideno znanje (projektne aktivnosti 2.1.5 Načrtovanje učnega e-okolja, 2.5.6 Definiranje grafičnih elementov $\mathrm{k}$ vajam in nalogam) ter tipe nalog (2.5.5 Vaje in naloge za besedilno raven), ki se povezujejo s projektnimi aktivnostmi, kot so 2.6 Baza znanja, 5.7 Vključevanje študentov, 4.1 Pridobivanje povratnih informacij ipd. 


\section{BERTA dobiva podobo}

Za pripravo vaj, usmerjenih $\mathrm{v}$ razumevanje in tvorjenje besedil, je bistvenega pomena širši nabor besedil različnih besedilnih skupin, ${ }^{1}$ tradicionalno imenovanih besedilne vrste. V okviru projekta Slovenšcina na dlani tako nastaja korpus besedil praktičnega sporazumevanja, ki smo ga poimenovali BERTA. Besedilni korpus BERTA je statična zbirka, ki načrtovano vsebuje okrog 250 pisnih in govorjenih besedil. Zbrana besedila smo združili v 22 premišljeno zasnovanih tematskih sklopov, ki smo jih poimenovali z naslednjimi slogani: 1. Lačen kot lakotnik, 2. Za vsakim dežjem posije sonce, 3. Zdrav duh v zdravem telesu, 4. Zakladnica modrosti, 5. Srě́e kovač, 6. Ce se prepirata dva, 7. Modri planet, 8. Naj te internet ne ujame v past, 9. Z glavo na zabavo, 10. V sak konec je nov začetek, 11. V sake ori imajo svojega malarja, 12. Brez njih bi bil svet drugačen, 13. V si smo delček istega sveta, 14. Bodi del spremembe, 15. Korak za korakom, 16. Ujemi svoje sanje, 17. O življenju skozi literaturo, 18. Lepa beseda lepo mesto najde, 19. Labkih nog naokrog, 20. Življenje ni potica, 21. Spremembe so na vidiku, 22. Z drugega zornega kota.

Slogani predstavljajo tematsko zaokroženo skupino besedil vsaj dveh različnih besedilnih skupin. Dvanajst sloganov je namenjenih osnovnošolskemu nivoju izobraževanja, deset pa srednješolskemu. Vendar bodo srednješolski uporabniki lahko reševali naloge in vaje za osnovnošolski nivo ter obratno. Tabela 1 natančneje prikazuje razporeditev sloganov po nivoju izobraževanja.

Tabela 1: Prikaz razporeditve sloganov po razredih in letnikih

\begin{tabular}{|l|l|}
\hline$\underline{\text { OS }}$ & Š́: \\
6. razred -4 slogani & 1. letnik -3 slogani \\
7. razred -3 slogani & 2. letnik -3 slogani \\
8. razred -2 slogana & 3. letnik -2 slogana \\
9. razred -3 slogani & 4. letnik - 2 slogana \\
\hline
\end{tabular}

\footnotetext{
1 Termin skupina besedil oziroma besedilna skupina uporabljamo kot nadpomenko za besedilne vrste in besedilne tipe. Pregled učnih gradiv je pokazal, da se v izobraževalnem procesu pogosteje obravnavajo besedilni tipi in da se ne razlikuje med besedilnimi vrstami in besedilnimi tipi.
} 
Zbirko BERTA trenutno tvori čez 250 vsakdanjih besedil (200 zapisanih in skoraj 70 govorjenih). Kot je bilo predstavljeno že v strokovni monografiji Slovenščna na dlani 1 (Krajnc Ivič 2018a), smo nabor besedil oblikovali tako, da zajeta besedila predstavljajo dnevno tvorjene ali interpretirane skupine besedil, ki spodbujajo kritičen odnos do prebranega, videnega ali slišanega, so didaktično ustrezne in strokovno dobro predstavljene, hkrati pa zanimive za učence in dijake. Končni nabor vključenih skupin besedil tako šteje 37 skupin besedil s podskupinami: življenjepis - pripoved o življenju osebe; (2) življenjepis - opis življenja osebe; (3) življenjepis - predstavitev osebe; (4) življenjepis - življenjepis; (5) pritožba; (6) prijava; (7) prijavnica; (8) prošnja za ...; (9) komentar; (10) kolumna; (11) kritika; (12) ocena - knjiga; (13) ocena - film; (14) poljudnoznanstveni prispevek - zapisano; (15) poljudnoznanstveni prispevek - videoposnetek; (16) novica; (17) horoskop; (18) vabilo; (19) pogovor - telefonski - pripovedni; (20) pogovor - telefonski - pogajalni; (21) pogovor - neposredni - pripovedni; (22) pogovor - neposredni - prepričevalni; (23) pogovor - neposredni - pogajalni; (24) intervju - ustni razgovor s strokovnjakom; (25) intervju - pisni razgovor s strokovnjakom; (26) referat; (27) govorni nastop - govorni nastop; (28) govorni nastop - predavanje; (29) šala; (30) anekdota; (31) oglas; (32) mali oglas; (33) vremenska napoved; (34) kuharska oddaja; (35) kuharski recept; (36) opis postopka in (37) popevka.

V izhodišču smo težili $\mathrm{k}$ temu, da za vsako skupino besedil zberemo isto število primerov besedil. Tako zajema npr. slogan Lačen kot lakotnik 5 kuharskih receptov in 5 novic, pri čemer imata en kuharski recept in ena novica isto tematiko. Skupaj ima slogan torej 5 tematik.

Porazdelitev števila skupin besedil po razredih in letnikih je sledeča: v 6. razredu OŠ bodo lahko učenci izbirali med enajstimi besedilnimi vrstami oziroma skupinami, $v$ 7. razredu med osmimi besedilnimi skupinami, za 8. razred je vključenih šest besedilnih skupin, devetošolci pa lahko izbirajo med devetimi besedilnimi skupinami. Dijaki 1. letnika SŠ bodo imeli na voljo šest besedilnih skupin, v 2. letniku sedem, 3. osem in v zadnjem, 4. letniku še sedem besedilnih skupin.

Naš namen - prispevati k učinkovitemu utrjevanju in izpopolnjevanju funkcionalne zmožnosti na enostaven, a privlačen način - je lahko v polnosti dosežen le ob strokovno primernih in didaktično ustreznih ter zanimivih in splošno uporabnih besedilih. Zbiranja besedil smo se lotili sistematično $-\mathrm{z}$ željo, zbrati čim bolj avtentična in raznolika besedila, smo ubrali različne načine zbiranja, v pomoč pa so 
nam bili tudi učitelji in profesorji $\mathrm{v}$ projektu sodelujočih vzgojno-izobraževalnih zavodov, ki so besedila zbirali s pomočjo ustvarjalnosti svojih učencev in dijakov. Tem se še posebej zahvaljujemo za sodelovanje, saj so $\mathrm{v}$ pripravo besedil, tudi govornih nastopov in telefonskih pogovorov, vložili veliko truda in prostega časa. Besedila, zajeta $\mathrm{v}$ zbirko BERTA, se bodo uporabniku prikazovala $\mathrm{v}$ naslednjih oblikah: PDF (izhodiščne wordove datoteke, npr. življenjepis); JPG (slike npr. spletnih strani, kjer je bilo besedilo objavljeno, npr. novica); avdioposnetek (mp4, wav, npr. telefonski pogovor); videoposnetek (youtube ali govorni nastop, npr. kuharska oddaja).

\section{Cilji in znanja}

Temeljni cilj vaj in nalog na področju besedil je razvijanje funkcionalne oziroma bralne pismenosti, ki jo tudi Bela knjiga (2011) navaja kot končni namen jezikovnega pouka. Po mednarodni opredelitvi Unesca (1978) je oseba funkcionalno pismena, če zmore (so)delovati »v vseh življenjskih dejavnostih, $\mathrm{v}$ katerih se zahteva pismenost za vsakodnevno delovanje $\mathrm{v}$ družbeni skupnosti, ter uporablja svoje bralne, pisne in številčne spretnosti za osebni razvoj in razvoj družbene skupnosti« (Bešter 1996: 59). Kadar je govora o funkcionalni pismenosti, torej ne moremo mimo temeljnih sporazumevalnih dejavnosti - te so govorjenje, pisanje, poslušanje in branje. To poudarja tudi Majda Cencič (1999: 4), ki pismenost opisuje kot »zapleteno, sestavljeno in povezano dejanje in proces, ki ne obsega le pisanja in branja, ampak tudi govorjenje in poslušanje«. Novejše raziskave namesto termina funkcionalna pismenost uporabljajo termin bralna pismenost, ki »je stalno razvijajoča se zmožnost posameznika/posameznice za razumevanje, kritično vrednotenje in uporabo pisnih informacij. Ta zmožnost vključuje razvite bralne veščine, (kritično) razumevanje prebranega, pojmovanje branja kot vrednote in motiviranost za branje ter druge gradnike bralne pismenosti. Kot taka je temelj vseh drugih pismenosti in je ključna za samouresničevanje posameznika/posameznice ter uspešno (so)delovanje v družbi.« (Gradniki bralne pismenosti, Delovno gradivo, ZRSŠ, 2018). Nacionalna strategija za razvoj bralne pismenosti sledi spoznanjem stroke o modelu kritične sporazumevalne (jezikovne) zmožnosti. Prav znanje o besedilnih vrstah (žanrih oziroma skupinah) pa sodi med nujna znanja, da lahko govorimo o kritični jezikovni sporazumevalni zmožnosti govorca nekega jezika. Potreben je torej prenos teh znanj v pedagoško prakso, saj ustrezno visoka besedilnovrstna pismenost »uporabnikom jezika zagotavlja prepoznavanje in učinkovito rabo žanrov« (Nidorfer Šiškovič 2013: 273) in omogoča aktivnejše vključevanje v družbeno in družabno življenje. 
Omenjeno delovno gradivo ZRSŠ kot gradnike bralne pismenosti navaja: 1) motiviranost za branje, 2) razumevanje koncepta bralnega gradiva, 3) glasovno zavedanje, 4) besedišče, 5) tekoče branje, 6) razumevanje besedil, 7) odziv na besedilo in tvorjenje besedil, 8) kritično branje. V okviru projekta Slovenšina na dlani pri besedilni ravni v prvi vrsti razvijamo gradnike 6 (razumevanje besedil), 7 (odziv na besedilo in tvorjenje besedil) in 8 (kritično branje). Hkrati s temi osrednjimi gradniki je pozornost namenjena tudi gradnikom besedišče (4), tekoče branje (5) in motiviranost za branje (1). Vaje in naloge za razvoj gradnikov oziroma za doseganje ciljev oblikujemo skladno s stopnjo šolanja (2. VIO OŠ, 3. VIO OŠ, SŠ).

Glede na učni načrt za slovenščino v osnovni šoli je eden temeljnih ciljev pouka slovenščine razvijanje sporazumevalne zmožnosti v slovenskem (knjižnem) jeziku, tj. zmožnosti razmišljujočega in kritičnega sprejemanja, razumevanja, doživljanja, vrednotenja in oblikovanja besedil raznih vrst, temeljni cilj jezikovnega pouka $\mathrm{v}$ gimnaziji pa je vzgojiti jezikovno, narodno in državljansko ozaveščenega in samozavestnega dijaka, ki bo tudi kultivirani in suvereni sogovorec, govorec in pisec ter kritični poslušalec/gledalec/bralec raznovrstnih neumetnostnih besedil. Temeljni cilji e-orodja Slovenš̌ina na dlani na področju besedil so tako pri uporabniku: 1) izboljšati in poglobiti razumevanje besedil različnih skupin; 2) razviti kritično razumevanje, ne le branje; 3) omogočiti uporabniku, da prikaže svoje razumevanje prebranega, slišanega, videnega besedila glede na konkreten kontekst in splošne značilnosti neke besedilne skupine ter da 4) izboljša svojo zmožnost tvorjenja raznovrstnih besedil.

Vse navedeno predstavlja izhodišče za oblikovanje nabora vrst znanja, ki jih razvija e-okolje Slovenščna na dlani za področje besedil. Te vrste znanja smo združili v dva temeljna sklopa, od katerih je prvi razvijanje zmožnosti razumevanja besedil in drugi razvijanje zmožnosti tvorjenja besedil. Tu združeno navajamo ključne vrste znanja za obe zmožnosti, saj so določene vrste znanja potrebne pri realizaciji obeh zmožnosti. 
Uporabniki bodo razvijali zmožnost razumevanja in tvorjenja besedil tako, da bodo:

- poslušali/gledali/brali besedila različnih skupin besedil;

- opisali in prepoznali kontekstualne spremenljivke: udeležence, kraj in čas, družbeno razmerje, sporočevalni namen, temo, podteme, ključne besede, bistvene podatke, kanal itd.; razmerje med udeleženci; jezikovno zvrst;

- opisali in prepoznali značilnosti izbrane skupine besedil (zgradbene /npr. izrek vabila/, leksikalne, slovnične, oblikovne /krepki tisk/ in druge);

- obnovili besedilo;

- iskali zahtevane podatke $\mathrm{v}$ besedilu;

- razvrščali podatke iz besedila;

- primerjali značilnosti ene skupine besedil $z$ drugo in predstavili ugotovitve;

- povzeli temo, ključno misel;

- prepoznali, določili in utemeljili slogovni postopek;

- poiskali izraze, ki se nanašajo na isti del dejanskosti (nanašanjska zaporedja);

- izraze $\mathrm{v}$ besedilu nadomeščali $\mathrm{z}$ drugimi, ki so smiselni in pomensko primerljivi (sopomenke, nadpomenke, podpomenke);

- prepoznali napake in neustreznosti ter jih odpravili;

- označili neznane besede, zanje našli razlage v obstoječih e-virih;

- v besedilu označili jedrno ali izhodiščno informacijo (členitev po aktualnosti) tudi glede na rabljena besedilotvorna sredstva;

- tvorili novo besedilo izhodiščne besedilne vrste;

- opazovali, analizirali in vrednotili souporabnikovo besedilo;

- dopolnili rubrike v izbrani besedilni vrsti (prijavnica, življenjepis, mali oglas) in dopolnili besedila $z$ manjkajočimi besedilnimi enotami;

- tvorili različna govorna dejanja za isti sporočevalni namen in predstavili zanj ustrezne okoliščine;

- pri interpretaciji in tvorjenju v odvisnosti od konteksta smiselno upoštevali načela sodelovanja, vljudnosti in menjavanja udeležencev $\mathrm{v}$ udeleženskih vlogah;

- pretvorili dele zapisanega besedila v nebesedno sporočilo (grafi, preglednice, miselni vzorec, dispozicijske točke);

- preoblikovali besedilo glede na izhodiščni prenosnik (govorjeno v zapisano in obratno);

- sodelovali v igri vlog. 


\section{Vaje in naloge za besedilno raven}

Priprava vaj in nalog za besedilno raven je $\mathrm{v}$ teku, $\mathrm{v}$ iskanju najboljših možnosti pa so nastali že prvi osnutki in scenariji. Zbirka BERTA uporabniku e-orodja Slovenšcina na dlani prinaša, kot že omenjeno, vaje in naloge, s katerimi: 1) izboljšuje in poglablja razumevanje besedil različnih skupin; 2) razvija kritično razumevanje prebranega, videnega ali slišanega; 3) prikazuje svoje razumevanje prebranega, slišanega, videnega besedila glede na konkreten kontekst in splošne značilnosti neke besedilne skupine; 4) izboljšuje svojo zmožnost tvorjenja besedil.

Uporabnik bo imel možnost naloge reševati na več načinov, in sicer po:

1. TEMATSKIH SKLOPIH $-\mathrm{v}$ tem primeru se bodo uporabniku prikazali vsi tematski sklopi, ob kliku na sklop pa se mu bodo prikazale tematike;

2. SKUPINAH BESEDIL oz. BESEDILNIH VRSTAH - uporabniku se bodo pri tej izbiri najprej pokazala poimenovanja besedilnih vrst oziroma skupin besedil (npr. vremenska napoved), ob kliku na skupino pa bo dobil nabor tematskih sklopov ter nadalje tematik, znotraj katerih se obravnavajo konkretne skupine besedil;

3. STOPNJI (OŠ ali SŠ) - uporabniku se bodo ob izbiri razreda oziroma letnika prikazali vsi tematski sklopi/slogani in nadalje tematike za določeno stopnjo;

4. SLOGANU - uporabnik ob kliku na to izbiro vidi seznam vseh sloganov. Po izbiri načina reševanja nalog bo uporabnik izbral bodisi naloge, vezane na razumevanje besedil (razvijanje zmožnosti razumevanja besedila), bodisi naloge, ki so vezane na tvorjenje besedil (razvijanje zmožnosti tvorjenja besedila). Ob začetku reševanja nalog se bo vsakemu uporabniku najprej prikazalo besedilo, da ga prebere/vidi/sliši, nadalje pa mu bo prebrano/videno/slišano besedilo ves čas na voljo $\mathrm{v}$ zavihku ob robu, $\mathrm{v}$ kolikor bo želel kaj pogledati, preveriti, poiskati podatke $\mathrm{v}$ besedilu ipd.

\section{Način določanja, izbiranja besedila in nalog}

Ob vsakem besedilu predvidevamo vaj in nalog za okoli 90 minut reševanja, za dnevni trening pa toliko nalog, da jih povprečen uporabnik lahko reši v 30 minutah, tj. 5 ali 6 nalog. Uporabnik bo lahko vadil ali tematiko (vse besedilne vrste obravnavajo isto temo) ali besedilno vrsto istega tematskega sklopa (npr. narava). Če 
ne bo dosegel zadostnega števila točk pri reševanju določenega sklopa nalog, vezanih na besedilo določene besedilne skupine (npr. vremenska napoved za 28. 2. 2018), mu bo program dodelil novo nalogo iste besedilne skupine znotraj istega slogana (npr. vremenska napoved za 25. 8. 2018). Šele nato bo lahko nadaljeval z vajami in nalogami za drugo besedilno skupino znotraj istega slogana. Če uporabnik e-okolja pri prvem reševanju ne bo zbral minimalnega števila točk, potrebnega za napredovanje, mu bo program dodelil določeno število nalog, ki jih še ni reševal. Če mu še vedno ne bo uspelo zbrati zadostnega števila točk, mu bo program dodelil novo besedilo iste skupine besedil $z$ istim naborom nalog kot pri prvem reševanju.

Orodje bo prav tako dopuščalo možnost, da naloge določi učitelj ali pa program sam. V tem smislu bo na voljo več možnosti - učitelj bo lahko vsem učencem ali dijakom določil: 1. isto besedilo in iste naloge, 2. isto besedilo, vendar različne naloge, 3. različna besedila iste skupine besedil in iste naloge, 4. različna besedila iste skupine besedil in različne naloge. Ena od možnosti bo tudi delo v skupinah, pri čemer bodo lahko imeli člani iste skupine isto besedilo in iste naloge ali pa bodo imeli člani iste skupine isto besedilo, toda različne naloge. Tako bodo lahko vsi člani skupine rešili skupno vse naloge in bo omogočena razprava med njimi. Učitelj naj bi imel tudi možnost učencu, ki še ni zbral zadostnega števila točk za napredovanje, omogočiti, da lahko napreduje, ker trenutno obravnavana učna snov to zahteva.

\section{Predvideni tipi nalog}

Zastavljene cilje in predvidene vrste znanja bo uporabnik na področju besedil razvijal prek dvanajstih različnih tipov nalog za razumevanje in tvorjenje besedil, in sicer prek:

- nalog dopolnjevanja;

- nalog s kratkim odgovorom;

- izbirnega tipa nalog z 1 pravilnim odgovorom/z 2 pravilnima odgovoroma/več pravilnimi odgovori/različno stopnjo pravilnosti odgovorov/z nepravilnim odgovorom;

- nalog povezovanja;

- nalog urejanja;

- alternativnega tipa nalog, lahko tudi z utemeljitvijo;

- nalog vstavljanja;

- nalog označevanja; 
- nalog popravljanja;

- nalog razvrščanja;

- nalog, ki predvidevajo sodelovanje $\mathrm{z}$ drugimi uporabniki;

- nalog s prostim odgovorom.

Spreminjanje stopnje zahtevnosti nalog in upoštevanje Bloomove taksonomije ponazarjamo s primerom določanja slogovnega postopka. Od uporabnika bomo torej želeli pridobiti informacije o tem, kateri slogovni postopek (opisovanje, pripovedovanje, razlaganje ali utemeljevanje) je tvorec uporabil pri tvorjenju besedila. Predstavljamo si, da je najpreprostejši način, da to informacijo pridobimo od uporabnika z nalogo alternativnega tipa, ko uporabnik obkroži da, če trditev drži, oziroma ne, če trditev ne drži, zato ta tip naloge predvidevamo za 6. razred. V 7. razredu bomo ta podatek iskali $\mathrm{z}$ nalogo označevanja pravilnega odgovora ( $\mathrm{v}$ povedi obkroži pravilno možnost: $\mathrm{Za}$ prebrano besedilo je żnačilno opisovanje/pripovedovanje/rąlaganje/utemeljevanje kot slogovni postopek). V 8. razredu bo uporabnik izbral (obkrožil) pravilni odgovor med štirimi možnimi. V 9. razredu bo poved popravil tako, da bo trditev pravilna (naloga popravljanja): Za prebrano besedilo je značilno utemeljevanje kot slogovni postopek. ${ }^{2} \mathrm{~V}$ 1. letniku predvidevamo, da bo uporabnik tvoril kratek odgovor, tj. sam napisal rešitev. V 2. letniku naj bi dano poved dopolnil z manjkajočim podatkom, $\mathrm{v}$ 3. utemeljil svoj odgovor (alternativni tip naloge $\mathrm{z}$ utemeljitvijo), $\mathrm{v}$ četrtem pa na osnovi primerov iz izhodiščnega besedila prepoznal, določil slogovni postopek in svojo določitev utemeljil (naloga s prostim odgovorom).

\section{Kako bo uporabnik pridobil povratno informacijo o pravilnosti rešitve?}

Pri pripravljanju vaj in nalog za področje besedil hkrati z naborom tipov nalog oblikujemo že tudi nabor prednostnih besedil. To so prototipična besedila neke skupine besedil. $\mathrm{Ob}$ teh prototipičnih besedilih bomo oblikovali vaje in naloge, ki se bodo praviloma pojavljale ob teh besedilnih skupinah. Hkrati z oblikovanjem nalog načrtujemo že tudi posamezne rešitve in načine, kako bodo te dostopne uporabniku. Del nalog bo pregledan avtomatsko, saj bo računalniški program pridobil podatke iz korpusnih oznak, t. i. šifrantov. Vsakemu besedilu, zajetemu v korpus BERTA, ob vnosu v korpus določimo podatke o tvorcu, naslovniku, kraju in datumu tvorjenja, slogovnem postopku, kanalu, sporočevalnem namenu idr. Določenemu delu nalog

\footnotetext{
${ }^{2}$ Uporabnik utemeljevanje nadomesti recimo s pripovedovanje.
} 
bomo pravilne rešitve dopisali sami. Uporabnik pa naj bi svojo rešitev primerjal z našimi danimi možnostmi. Pri pregledovanju nekaterih nalog je predvideno tudi sodelovanje z drugimi v smislu „Posvetuj se z drugimi uporabniki““/„Preveri pri drugih uporabnikih.“

Naloge bodo obogatene $z$ namigi, ki bodo spodbujali $k$ reševanju in reševanje olajšali. Uporabnik si bo tako lahko pomagal npr. s premetanko (npr. iz soip optoskap bo lahko razbral poimenovanje besedilne skupine opis postopka) ali z rešetom, s škatlo, piknikom besed, kjer bo med različnimi poimenovanji besedilnih skupin poiskal pravo. Za dodatno spodbudo pa bodo služili pripisi tipa: Odlično, bravo; Raje preberi ̌̌e enkrat; Saj bo šlo; Hm hm ipd.

\section{Sklep}

Zbiranje in pridobivanje soglasij za vključitev in uporabo besedil $\mathrm{v}$ besedilni korpus BERTA, ki poteka od septembra 2018, se počasi približuje koncu. Zbrana besedila, razvrščena po sloganih in skupinah besedil (npr. opis postopka, vremenska napoved, esej, življenjepis) bodo opremljena s šifranti, ki bodo omogočali tudi avtomatsko pregledovanje uporabnikovih rešitev. Rešitve pri nekaterih tipih nalog (npr. naloge s prostim odgovorom) pa naj bi uporabnik primerjal s ponujenimi rešitvami, s čimer bo še dodatno razvijal funkcionalno oziroma bralno pismenost. To pa je tudi temeljni cilj vaj in nalog za področje besedil.

\section{Literatura}

Bela knjiga o vagoji in izobraževanju v Republiki Sloveniji, 2011. Ur. Janez KREK in Mira METLJAK. Ljubljana: Pedagoški inštitut.

Marja BEŠTER, 1996: Funkcionalna pismenost kot osnovni cilj jerikornega pouka pri predmetu slovenski jezilk. Radovljica: Didakta.

Marja BEŠTER, 2011: Sporazumevalna zmožnost - eden izmed temeljnih ciljev pouka slovenščine. Jerik in slovstvo 56/3-4, 111-130.

Majda CENCIČ, 1999: Pojem pismenosti kot celostne in sestavljene aktivnosti, njeno razvijanje ter poučevanje. Vzgoja in ižobrą̌evanje 4, 4-12.

Gradniki bralne pismenosti. Delovno gradivo, nastalo v okviru projekta OBJEM - Bralna pismenost in razvoj slovenščne kot učnega jęika (https://www.zrss.si/objava/projekt-objem), vodja dr. Sandra Mršnik. ZRSŠ, 2018.

Mira KRAJNC IVIČ, 2018: Besedilne vrste v slovenskem besediloslovju. Jerik in slovstvo 63/2-3, 7586, 276.

Mira KRAJNC IVIČ, 2018a: Kdo ali kaj je BERTA. Slovenščina na dlani 1. Ur. Natalija Ulčnik. Maribor: Univerzitetna založba Univerze v Mariboru. 65-72. 
Nacionalna strategija za razuoj pismenosti, 2006. Dostop 5. 2. 2019 na: http://www.mizs.gov.si/si/delovna_podrocja/urad_za_razvoj_in_kakovost_izobrazevanja/ projekti/pismenost/.

Mojca NIDORFER ŠIŠKOVIČ, 2013: Žanrskost funkcijskih besedilnih vrst. Družbena funkeijskost jezikea (vidiki, merila, opredelitve). Ur. Andreja Žele. Ljubljana: Znanstvena založba Filozofske fakultete. 269-275.

Mojca POZNANOVIČ JEZERŠEK idr., 2008: UČNI načrt. Slovenščna. Gimnarija: splošna, klasična, strokovna gimnarija. Ljubljana: Ministrstvo za šolstvo in šport: Zavod RS za šolstvo. Dostopno 20.0618 na: http://eportal.mss.edus.si/msswww/programi2010/programi/media/pdf/un_gimnazija/un _slovenscina_gimn.pdf.

Mojca POZNANOVIČ JEZERŠEK idr., 2018: Učni načrt. Program osnovna šola. Slovenščna. Ljubljana: Republika Slovenija, Ministrstvo za izobraževanje, znanost in šport: Zavod Republike Slovenije za šolstvo. Dostopno $20 . \quad 6 . \quad 2018$ na: http://www.mizs.gov.si/fileadmin/mizs.gov.si/pageuploads/podrocje/os/prenovljeni_UN/ UN_slovenscina.pdf.

Priporočilo Evropskega sveta in Evropskega parlamenta $=$ Ključne kompetence za vsě̌iviljenjsko ǚenje - evropski referenčni okvir, 2006. Uradni list EU 2006: L 394. Dostopno 15. 5. 2018 na: http://www.kulturnibazar.si/data/upload/Priporocilo.pdf.

Jerca VOGEL, 2014: Jezikovna kulturna zavest pri pouku maternega/prvega jezika. Jezile in slovstvo $59 / 4,3-14$. 


\section{PORAZZLIČNIH POTEH DO ZNANNIA SLOVENŠČINE}





\title{
Učenje slovnice s pomočjo zgodbe
}

\author{
PETRA KODRE
}

Povzetek Članek želi prikazati, kako je na predmetni stopnji osnovne šole besedne vrste mogoče poučevati z zgodbo, pomnjenje pa učencem olajšati s pomočjo asociacije in likovne upodobitve. Podane zgodbe je mogoče preoblikovati in prilagoditi vsakokratni učni skupini, upoštevajoč učno klimo in posebnosti posameznikov. Zasledovani cilji so s prvih treh ravnin Bloomove taksonomske stopnje, ki jih morajo usvojiti vsi učenci, pri realizaciji pa je bila uporabljena kombinacija narativne učne metode in metode pogovora.

Ključne besede: $\bullet$ učenje $\bullet$ slovnica $\bullet$ zgodba $\bullet$ asociacija $\bullet$ ilustracija $\bullet$

NASlov AvTORICE: Petra Kodre, Osnovna šola Danila Lokarja Ajdovščina, Ajdovščina, Slovenija, epošta: petra.kodre@os-ajdovscina.si. 


\section{Trije osnovni učni tipi}

Pri poučevanju upoštevam, da imam pred seboj učence, ki se učijo na različne načine. Poznamo tri osnovne učne tipe: vidni ali vizualni, slušni ali avditivni ter motorični ali kinestetični. Besedne vrste poučujem $\mathrm{s}$ pomočjo zgodb, $\mathrm{v}$ katerih skušam upoštevati, da pri večini učencev prepoznamo kombinacijo vseh treh učnih tipov (prim. Dryen, Vos 2001; Kolb, Miltner 2005).

Sledi prikaz, kako je zgodbe mogoče uporabiti pri prepoznavanju in razločevanju besednih vrst, s katerimi se srečamo v osnovni šoli.

\section{Glagol}

V zgodbah želim uporabiti čim več besed, ki pripadajo tisti besedni vrsti, ki jo prikazujejo.

Iz tega razloga zgodbo o glagolu začnem z besedami: Pridite, pojdimo pogledat, kaj se tu dogaja. Učencem pokažem plakat, na katerem je delovišče. Na izpostavljenem mestu je napis: Ne moti, delamo! Postavim vprašanje, kaj osebe počnejo, in odgovore v obliki glagola zapisujem na tablo. Iz zapisanega oblikujemo ugotovitev o tem, kaj označuje glagol.

$\mathrm{Na}$ koncu učenci v svoj zvezek narišejo sebe pri opravljanju poljubnega opravila in zraven pripišejo: Ne moti, delam. Te besede postanejo geslo, zgledni primer, ki pomaga pri pomnjenju ter priklicu znanja o tem, kaj označuje glagol. Za dober izbor in učinkovito pomoč se izkaže tudi zaradi nikalne oblike, ki jo številni sicer radi pozabijo. Pri utrjevanju glagola sem posebej pozorna na to, da vedno popravim, če kdo reče, da smo pri glagolu risali delavce, saj le-ti sodijo k samostalniku.

\section{Samostalnik}

Ko pridejo učenci v šesti razred, bi samostalnik morali že prepoznavati. Ta cilj nekateri dosegajo, drugi ne, zato ga v šestem razredu spoznavamo na novo. Pri tem si pomagamo z zgodbo o nergaču, ki mu gre vse na živce. Učencem postavim vprašanje, kaj je tisto »vse«, kar mu lahko gre na živce, in določim, da morajo biti njihovi odgovori enobesedni. Domišljija dobi prosto pot, izvedemo možgansko nevihto in na tablo zapisujemo odgovore. Ugotovimo, da imamo na tabli same 
samostalnike, in iz tega izpeljemo slogan Samostalnik mi gre na živce. Ta se zaradi svoje provokativnosti učencem zdi zabaven, kar lahko še okrepimo, če v razredu izvedemo krajšo dramsko delavnico, $v$ kateri iščemo tega, ki bo najbolj doživeto odigral nergača, ki pravi: »Osebe, živali, rastline, predmeti in pojmi - vse mi gre na živce!« Za domačo nalogo morajo učenci nergača in njegov slogan prikazati še likovno.

Marsikateri učenec si tudi kasneje pri prepoznavanju samostalnikov pomaga z vprašanjem, ali ti neka stvar lahko gre na živce ali ne. Težava se pojavi le pri osebnih zaimkih, saj je na vprašanje kdo ti gre na živce mogoče odgovoriti npr. z on, ki pa ni samostalnik. Ampak ta problem se pojavi, tudi če sprejmemo definicijo, da k samostalnikom uvrščamo osebe, rastline, živali, predmete in pojme, saj npr. on sodi med osebe. Iz tega razloga je smiselno, da osebni zaimek obravnavamo neposredno za samostalnikom.

\section{Osebni zaimek}

Z osebnimi zaimki se učenci prvič srečajo v šestem razredu. Spoznamo jih prek zgodbe o dveh zaljubljenih mačkah, v kateri se skušamo čimbolj vživeti. Povemo, da se zaljubljenci radi umaknejo v kak skrit kotiček in da imajo osebne pogovore. Gledajo se v oči in si z nekaj kratkimi besedami vse povedo. Te besede so lahko jaz, ti, midva.

Če se v razredu javita prostovoljca, ki sta pripravljena odigrati tak prizor (največkrat sta to dva fanta), ga odigrata, sicer pa ga učenci le likovno upodobijo. Zaimki jaz, ti in midva nam kasneje služijo kot asociacija, s katero v spomin prikličemo še druge osebne zaimke.

\section{Svojilni zaimek}

Neposredno za osebnimi zaimki obravnavam svojilni zaimek, čeprav bi po učnem načrtu bil na vrsti v sedmem razredu. Za obravnavo že v šestem se odločim iz dveh razlogov:

- $\quad$ ker se ga da enostavno izpeljati iz osebnih zaimkov,

- da ga učenci pri obravnavi pridevnika ne bodo uvrščali med svojilne pridevnike, saj se po obojih vprašamo z vprašalnico čigav. 
Pri obravnavi svojilnih zaimkov uporabim zgodbo, v kateri poudarim besedo svojci (sorodniki). Učencem skušam kar se da doživeto pripovedovati o veliki družinski zabavi, na kateri sta dedek in babica praznovala zlato poroko. Praznovanje so jima priredili svojci, sorodniki, ki so jima hoteli pripraviti presenečenje, zato jima o tem niso vnaprej nič povedali. Slavljenca sta bila zelo presenečena in sta goste, svojce, vprašala, čigava ideja je to praznovanje. Oni niso hoteli povedati, zato je odgovor zanju ostal skrivnost. Še danes včasih vzameta $\mathrm{v}$ roko skupno fotografijo vseh udeležencev, ki je takrat nastala, in skušata to ugotoviti. Na glas razmišljata: Če je pobudo za praznovanje dala ona, je bila ideja njena. Če jo je dal on, je bila njegova. Če so jo dali oni, je njihova. Če bi jo dal jaz, bi bila moja. Če bi jo dala ti, bi bila tvoja. Če bi jo dala midva, bi bila najina. Če bi ju dala vidva, bi bila vajina itd.

\section{Povratni svojilni zaimek}

Ko v sedmem razredu obravnavamo povratni svojilni zaimek, učencem spet pokažem družinsko fotografijo s sorodniki - svojci, ki je nastala na praznovanju zlate poroke dedka in babice. Poudarim, da bomo imeli spet opravka s svojci, ki jih učenci zdaj že asociirajo s svojilnimi zaimki. Na fotografiji izberem mlajšega gospoda, poimenujem ga Janez, in učencem pripovedujem naslednjo zgodbo:

Janez je sosedu povedal, da z ženo odhajata na morje. Sosed ni bil najboljši poznavalec slovnice in je svoji ženi doma o tem poročal tako: »Janez je z njegovo ženo šel na morje.«Ta novica se je zelo hitro razširila po vasi in naslednji dan so že vsi govorili, da ima Janez ljubico, s katero je šel na morje, svojo ženo pa je pustil doma. Ko je ta vest prišla tudi do Janeza in njegove žene, ki sta počitnikovala ob morju, je ona rekla: »Le pazi se! Če bi me varal, nimaš več povratka $\mathrm{k}$ meni.»

Zgodbo zaključim s šaljivo opazko, da ima neznanje slovnice lahko zelo hude posledice, in naročilom, $v$ zvezek narisati Janeza in njegovo ženo na morju, spodaj pa napisati: Janez je šel na morje s svojo ženo. Iz ženinih ust narišemo oblaček s sporočilom: Če bi me varal, nimaš več pouratka $\mathrm{k}$ meni. 


\section{Pridevnik}

Čeprav pridevnik spoznajo že petošolci, ga v šestem razredu še enkrat predstavim v obliki zgodbe. Učencem postavim izziv: povem jim, da se sosed odloča o nakupu psa, in jih vprašam za nasvet, kakšnega naj vzame. Lastnosti, ki jih naštejejo, priden, prijazen, nenapadalen, lep, velik ..., zapišemo na tablo. Nato jih vprašam še po vrsti, ki jo svetujejo. Njihovi odgovori so npr.: kratkodlaki, pritlikavi, lovski, reševalni. Vse zapisano povzamemo v geslo priden sosedov lovski. Učenci ga zapišejo poleg lovskega psa, ki ga narišejo v zvezek.

Izbrano geslo se izkaže za dobro izbiro tudi zaradi besede priden, ki jo učenci lahko nadgradijo $\mathrm{v}$ priden pridevnik. Ta povezava prepreči zamenjevanje pridevnika in prislova, kar se med učenci zaradi enake začetnice sicer pogosto dogaja.

\section{Prislov}

Za optimalne rezultate pri procesu učenja je potrebno sproščeno okolje, zato je pri pouku občasno dobro poskrbeti tudi za razvedrilo. Zgodbe so odlično sredstvo za to.

Obravnavo prislova začnem tako, da učence vprašam, ali poznajo kakšno šalo o polžih. Po navadi kar tekmujejo med seboj, kdo jih bo povedal več. Nato njihovo skupno značilnost povzamemo v geslu: Vedno in povsod počasi in previdno! Sestavljeno je iz vseh treh vrst prislova, ki jih šestošolci poznajo, zato pot do pravilnih vprašalnic ne bo težka.

\section{Glavni števnik}

Pri obravnavi glavnega števnika spoznamo zgodbo o gospodu, ki si domišlja, da je glavni, ker ima veliko denarja. Ne zanima ga nič drugega, kot to, da šteje svoj denar. Pri tem uporablja glavne števnike. Učenci v zvezek narišejo gospoda, ki šteje denar in pravi: »Jaz sem glavni.« 


\section{Vrstilni števnik}

Pri obravnavi vrstilnih števnikov se odločim za precej predvidljivo zgodbo tekmovanje $v$ teku in podelitev medalj. Na vprašanje, kateri po vrsti je nekdo pritekel na cilj, učencem ni težko odgovoriti z vrstilnim števnikom.

\section{Oziralni zaimek}

Pri zgodbah je pomembno dobro prikazati značaj nastopajočih. Za to se še posebej potrudim pri Roberti, ki nam pomaga spoznavati oziralni zaimek. Predstavim jo kot malce posebno starejšo gospo, zaradi česar se vsi ozirajo za njo. Čeprav je že dolgo od takrat, ko je bila najstnica, se še vedno tako oblači. Učence spodbudim, da povedo, kako si jo predstavljajo. $\mathrm{K}$ njihovim opisom dodam, da ima doma zelo veliko uhanov, zapestnic, prstanov ..., ki jih zelo pogosto menjuje, edini nakit, ki ga nikoli ne odloži, je ogrlica s črko R. Na koncu izdam še Robertin priimek in delovno mesto. Povem, da se bo oziralni zaimek z nami učila Roberta Kateriki, ki dela v trafiki, kjer prodaja kikiriki. Osredotočimo se na njen priimek in v njem prepoznamo dva zelo pogosta oziralna zaimka - kateri in ki. Pri prepoznavanju drugih nam bo v pomoč izpostavljena črka R.

\section{Kazalni zaimek}

Pri kazalnem zaimku si pomagamo z zgodbo o nogometnem sodniku, ki teka po igrišču ter s prstom kaže na igralce in storjene prekrške. Zgodbo pospremimo z geslom ta, tisti, oni, takšen in ilustracijo.

\section{Vprašalni zaimek}

Vprašalni zaimek spoznavamo s pomočjo zgodbe o policistu z imenom Policaj Zakaj. Opravlja delo kriminalista, pri iskanju storilcev kaznivih dejanj vsem postavlja številna in najrazličnejša vprašanja. Učence spodbudim, da jih čim več povedo, vprašalnice napišemo na tablo. Nato učenci $v$ zvezek narišejo policista in ga imenujejo Policaj Zakaj. 


\section{Medmet}

Zgodba za predstavitev medmeta je bila oblikovana predvsem z mislijo na najpogostejšo težavo, ki jo imajo učenci pri prepoznavanju te besedne vrste - to je, da ga zamenjujejo s členkom. Zato v zgodbi o medmetu nastopa koza, ki pravi: $M e$ me-medmet. To učenci narišejo oz. napišejo v svoj zvezek. Nato jim dam izziv, da posnemajo glasove čim več različnih vrst živali. Po navadi se v vsakem razredu oz. učni skupini najde kdo, ki mu to uspe zelo doživeto, kar je za druge učence še posebej zabavno. Medmetom, ki posnemajo živalske glasove, pridružimo še druge posnemovalne, razpoloženjske in velelne medmete. Ko je vzdušje najbolj prijetno, učencem povem, da imam zanje žal eno slabo novico, ampak da jim jo bom zaupala šele naslednjo uro, saj ne želim, da so zaradi nje že zdaj preveč potrti. $\mathrm{Na}$ ta način ustvarim pričakovanje, ki ga naslednjo uro povežem s poučevanjem členka.

\section{Členek}

Učencem takoj po vstopu v razred povem, da jim bom danes razkrila slabo novico, a da imam tudi eno dobro. Začnem s slabo, glasi se: Skoraj smo že končali z obravnavo besednih vrst. Ostal nam je samo še členek, žal. Besede »žal samo še členek« napišem na tablo.

Dobra novica pa je ta, da ga ni težko prepoznavati, saj se v besedah, ki sem jih ravnokar napisala na tablo, skriva kar pet primerov zanj. Učenci jih skušajo prepoznati, po potrebi jim pomagam. Z iskanjem členkov še v drugih primerih ga še bolj utrdijo.

\section{Sklep}

Facts Tell, Stories Sell. Trgovci in turistični delavci že dolgo vedo, da so zgodbe dobra prodajna niša, zakaj jih ne bi več uporabili tudi v šoli? Te se dobro izkažejo tudi pri učenju slovnice in besednih vrst, ki so marsikateremu učencu dolgočasne in zato učitelju predstavljajo še poseben izziv. 
Kaj je uspešna zgodba in kako jo ustvariti?

Odgovor na prvo vprašanje je dokaj preprost - to je zgodba, ki dosega zastavljeni cilj, v šoli torej pripomore h kvalitetnejšemu in lažjemu pridobivanju znanja. Pri tem sta nam v pomoč sposobnost analognega sklepanja in asociativnega povezovanja. Zgodba naj ne bo predolga, vsebuje naj jasno izraženo misel, še bolje geslo. Otrokom so všeč skrivnostni in napeti pripetljaji, a srečni konci. Posebnega pomena so nastopajoči junaki, zato morajo ti imeti dobro orisan značaj. Na ta način je lažje doseči čustveno vpletenost poslušalcev ter možnost identifikacije $z$ nastopajočimi. Najboljše zgodbe imajo moč, da poslušalce spremenijo v njene pripovedovalce in soustvarjalce. Če se naselijo tako v glavah kot srcih poslušalcev, tam ostanejo za vedno.

\section{Literatura}

Gordon DRYDEN, Jeannette VOS, 2001: Revolucija učenja. Ljubljana: Educy.

Klaus KOLB, Frank MILTNER, 2005: Otroci se zlabke učijo. Ljubljana: Mladinska knjiga.

Slika 1: Plakat - glagol. Stran 79.

Slika 2: Plakati v razredu 1. Stran 80.

Slika 3: Plakat - osebni zaimek. Stran 81.

Slika 4: Plakati v razredu 2. Stran 82.

Slika 5: Plakat - povratni svojilni zaimek. Stran 83.

Slika 6: Plakat - pridevnik. Stran 84.

Slika 7: Plakat - oziralni zaimek. Stran 85.

Slika 8: Plakat - pisanje narazen. Stran 86. 


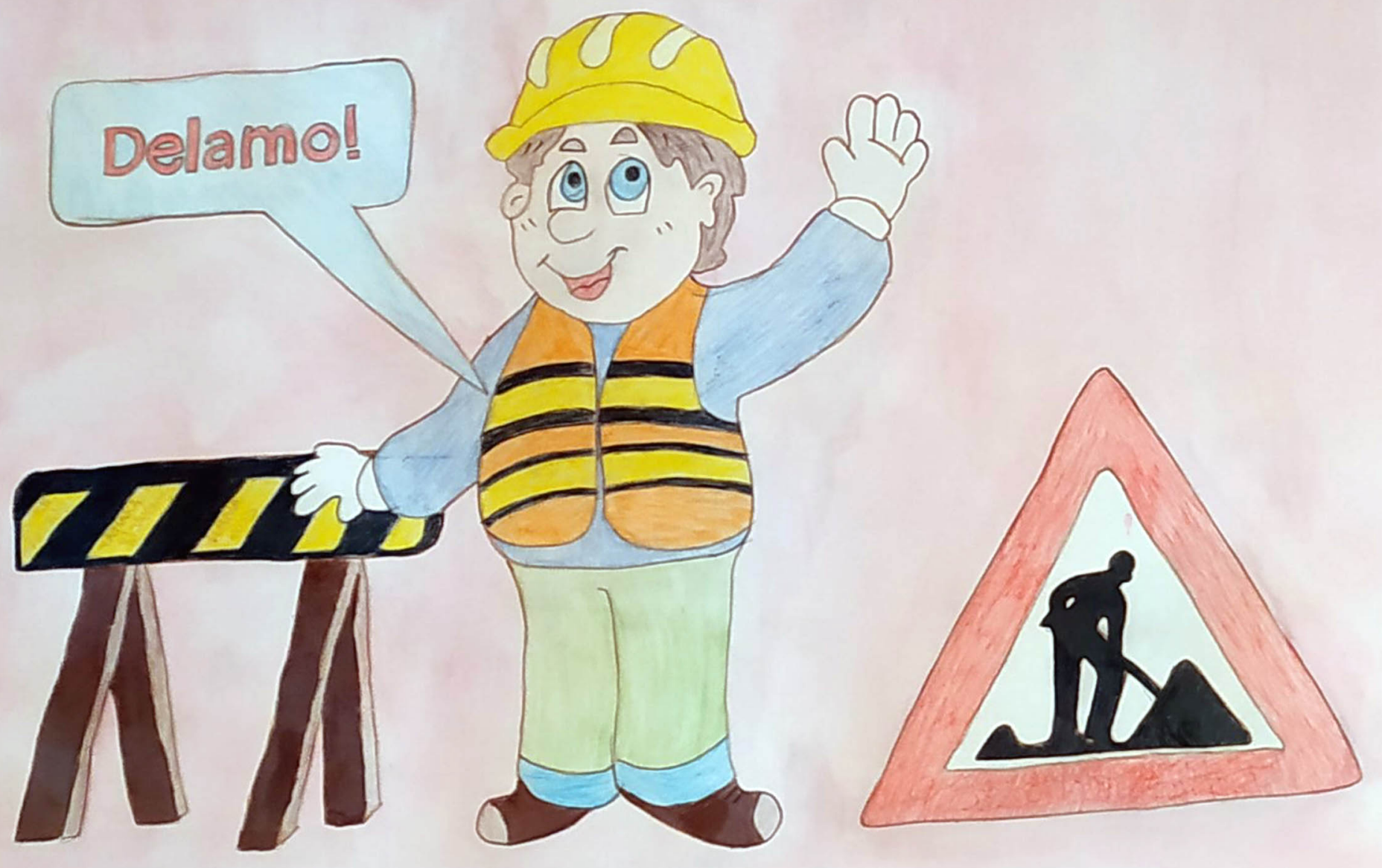

GLAGOL

$\sigma$ 


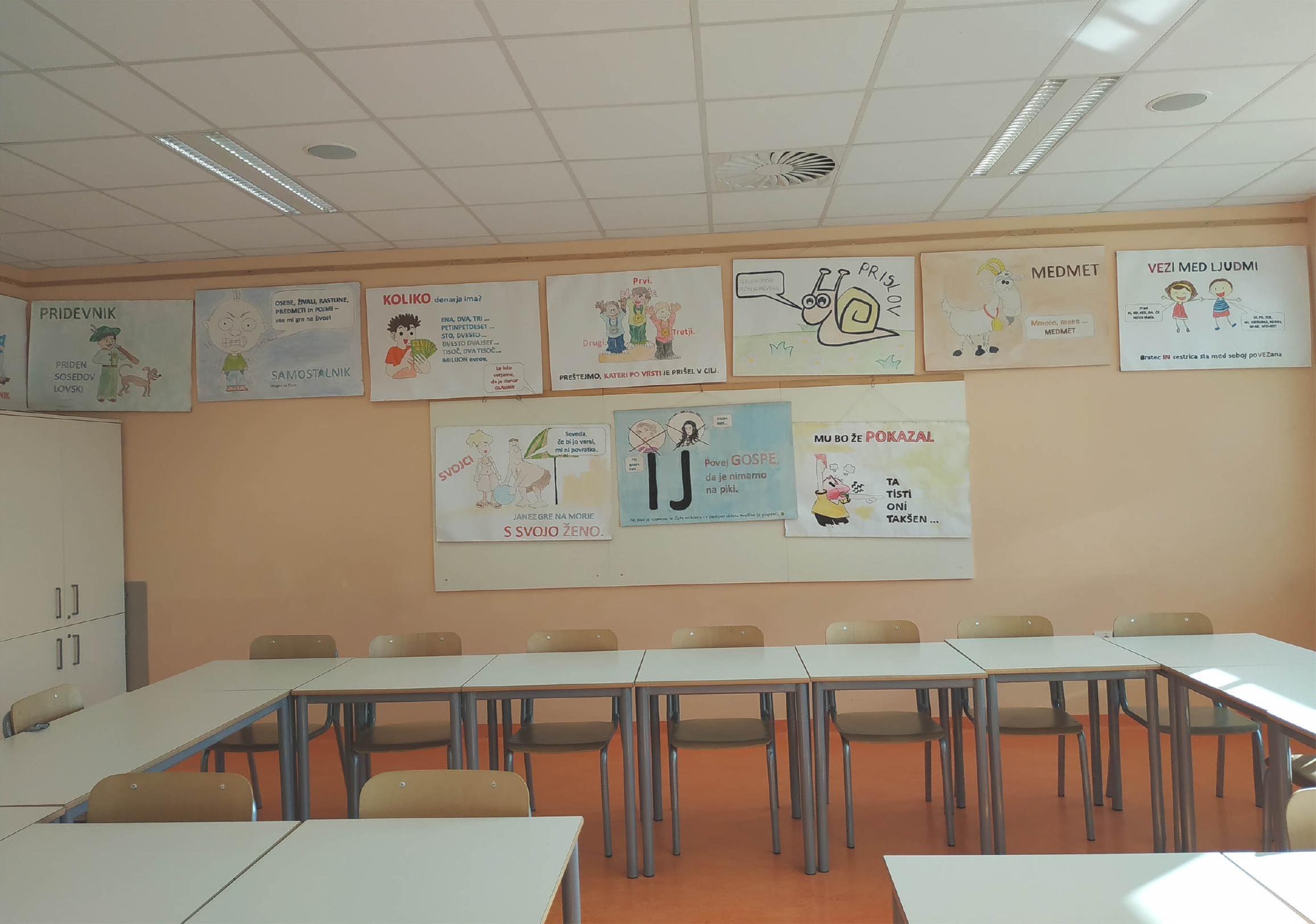


(OSEBNR DRNRER
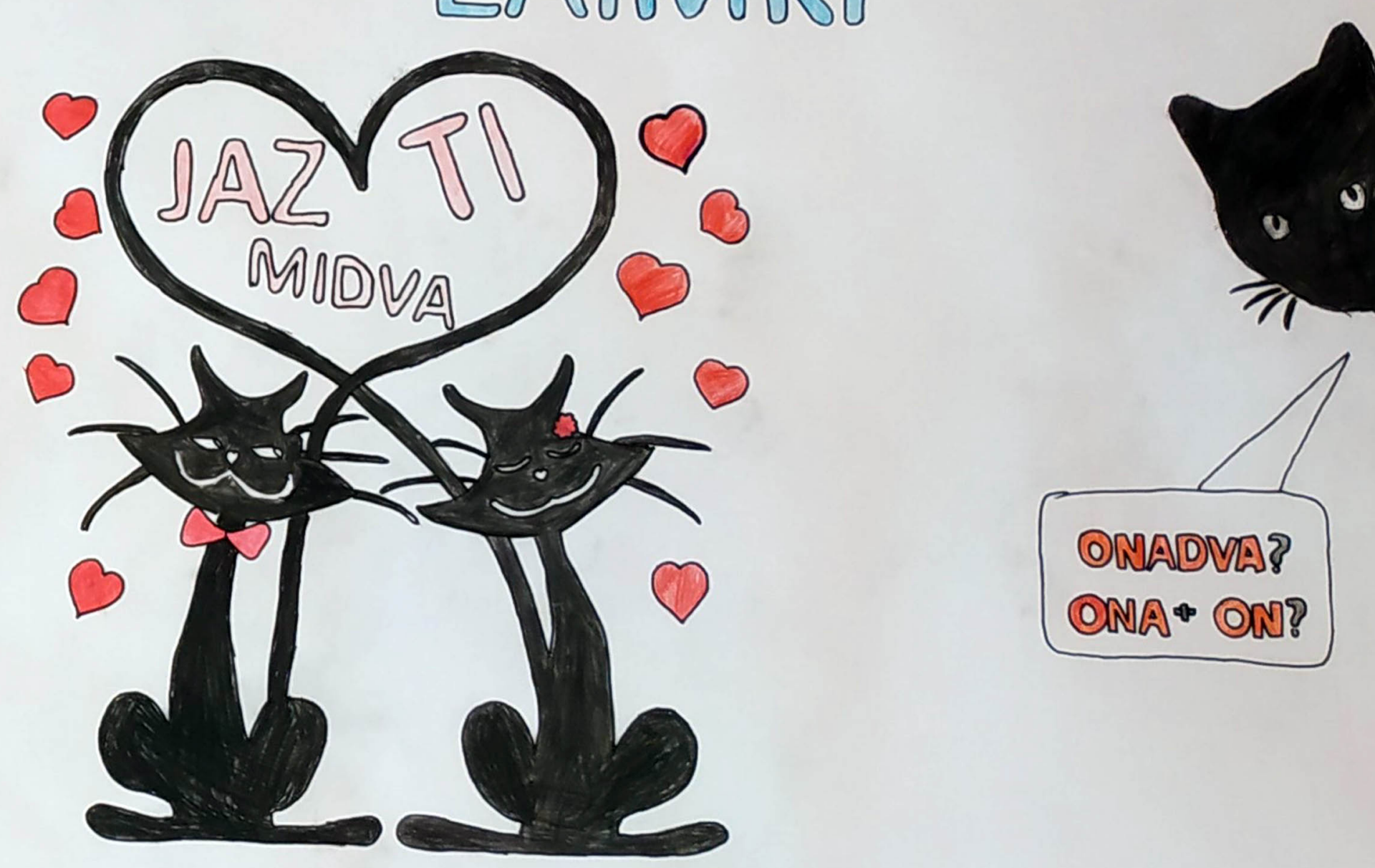
SVOJILNI ZAIMKI

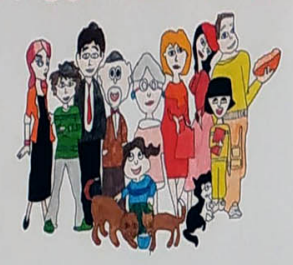

MOJA mama, TVOJA sestra, VAJN brat,

NAS ded, VAS sin, NJEN stric, NJUN unuk ...

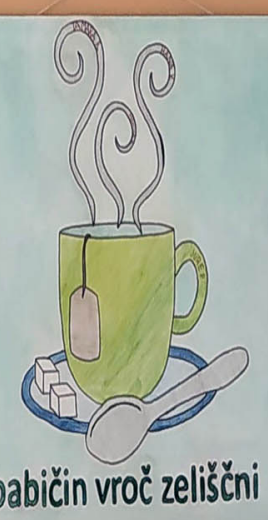

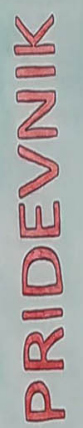

S KOM ali S ČiM si pomagăs? ZORODIEM.

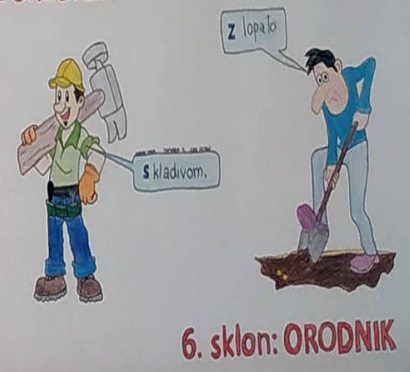

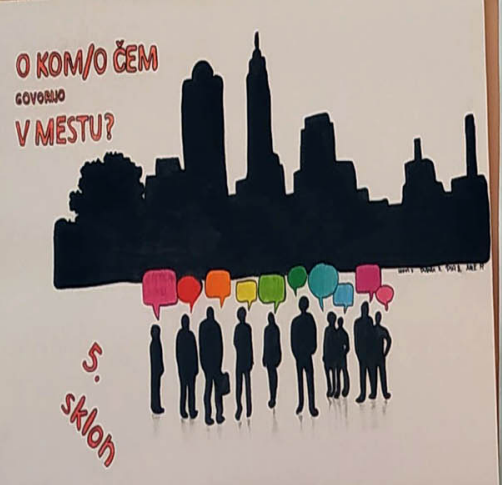

babičin vroč zeliščñ one

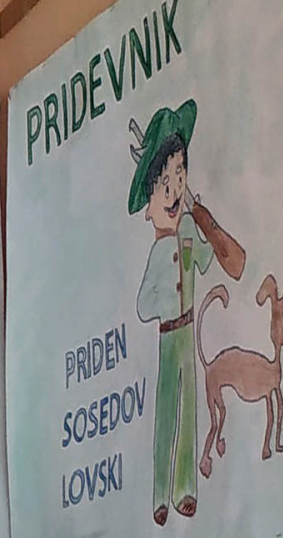

LOVSK

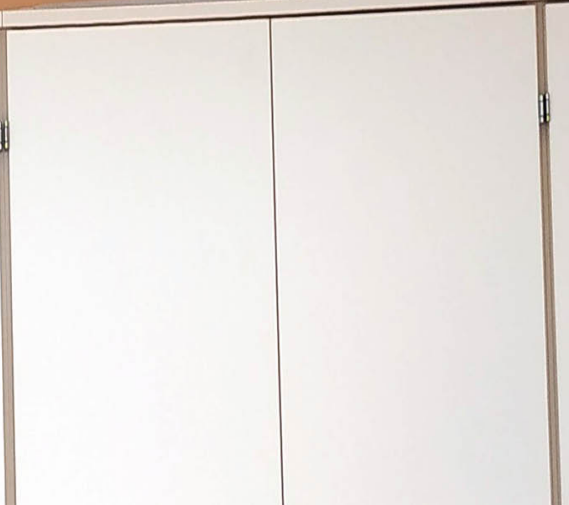




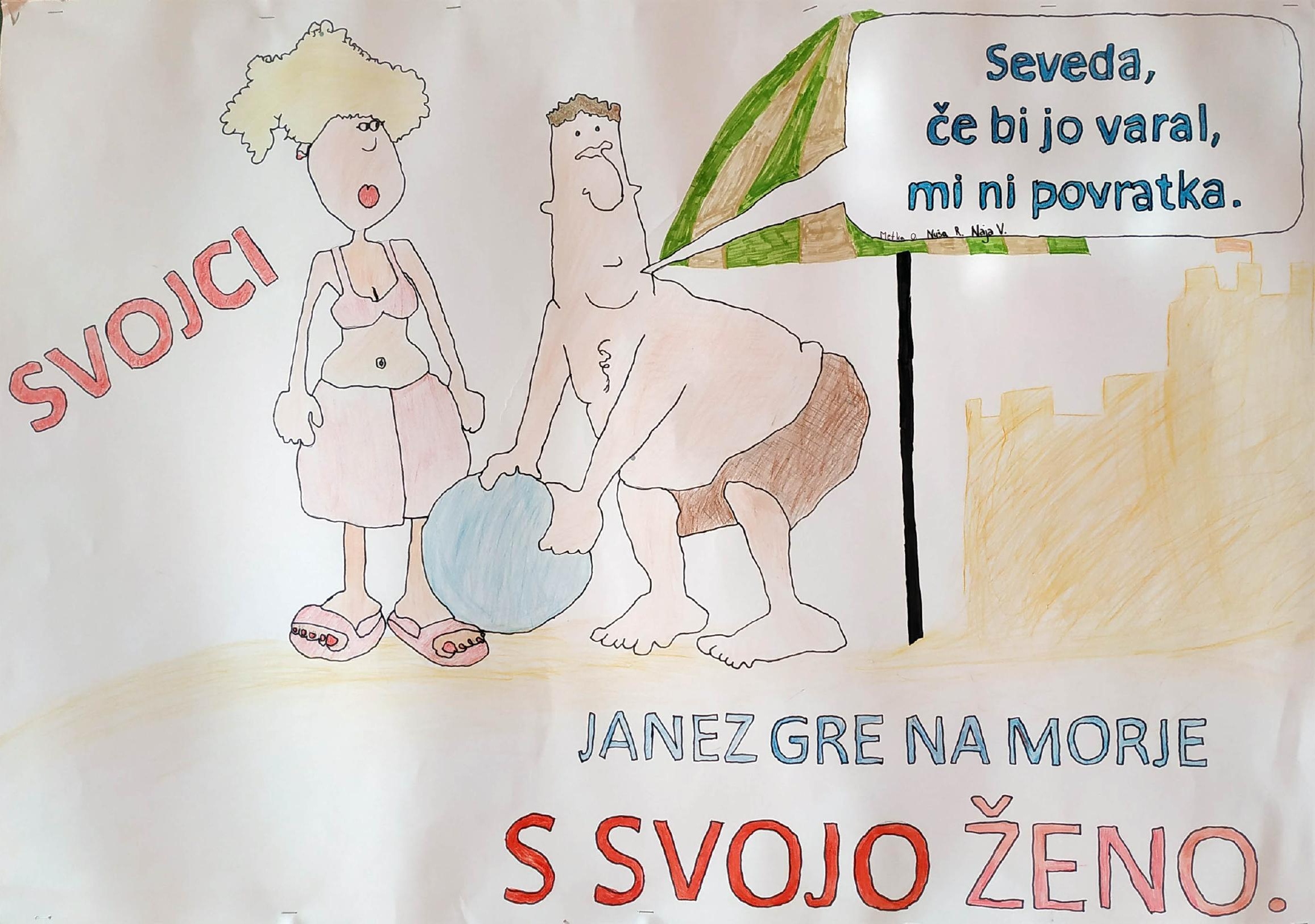




\section{PRIDEVNIK}

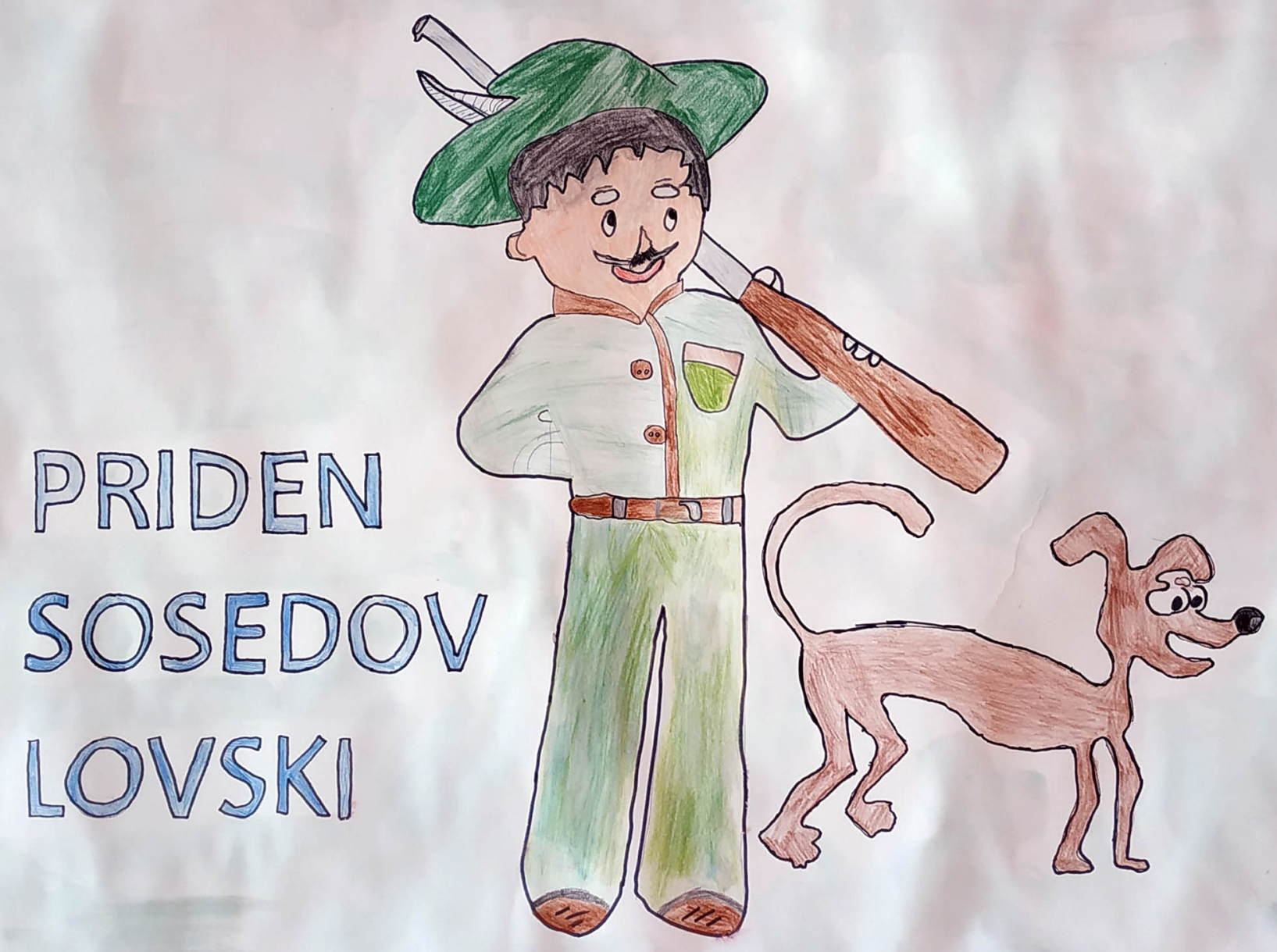




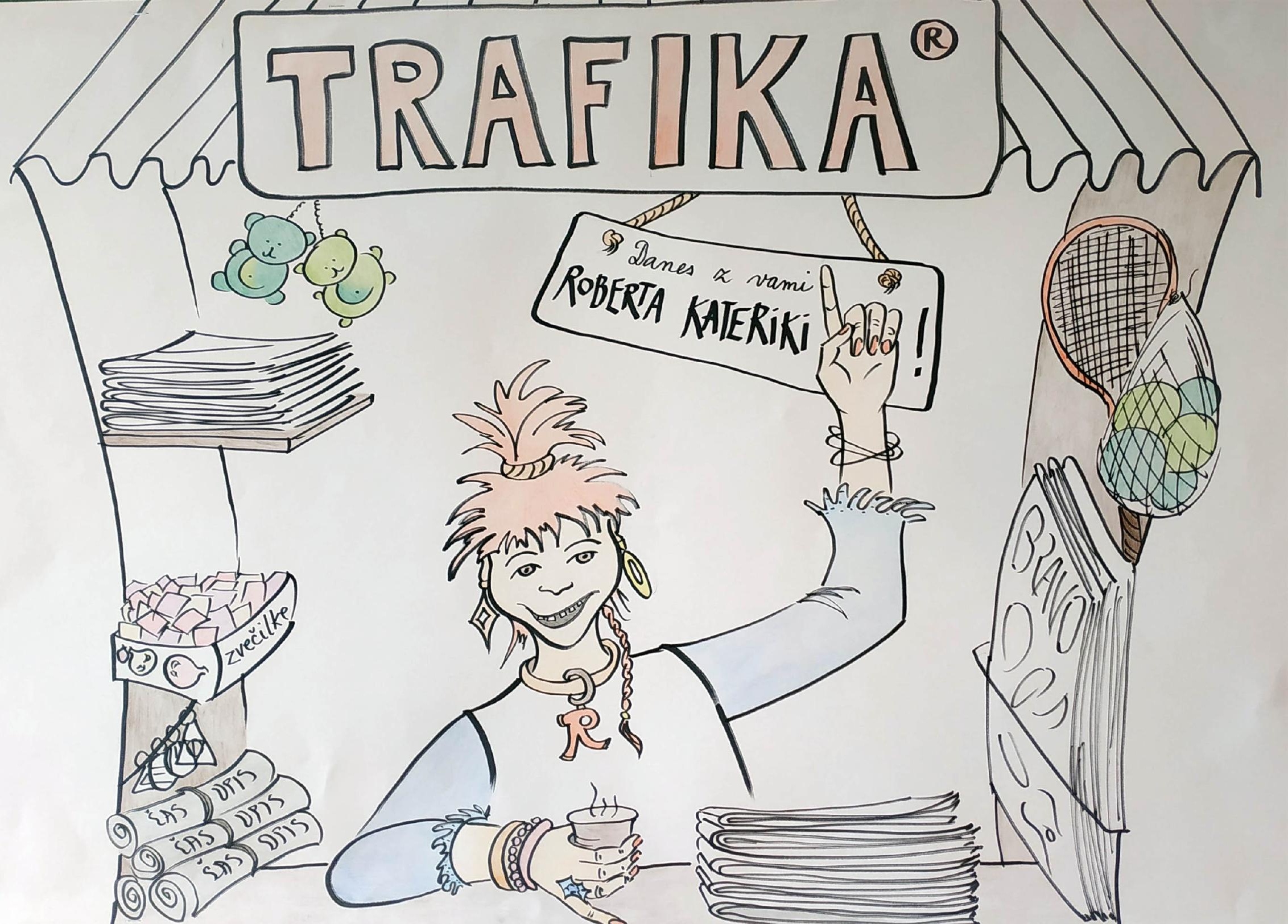




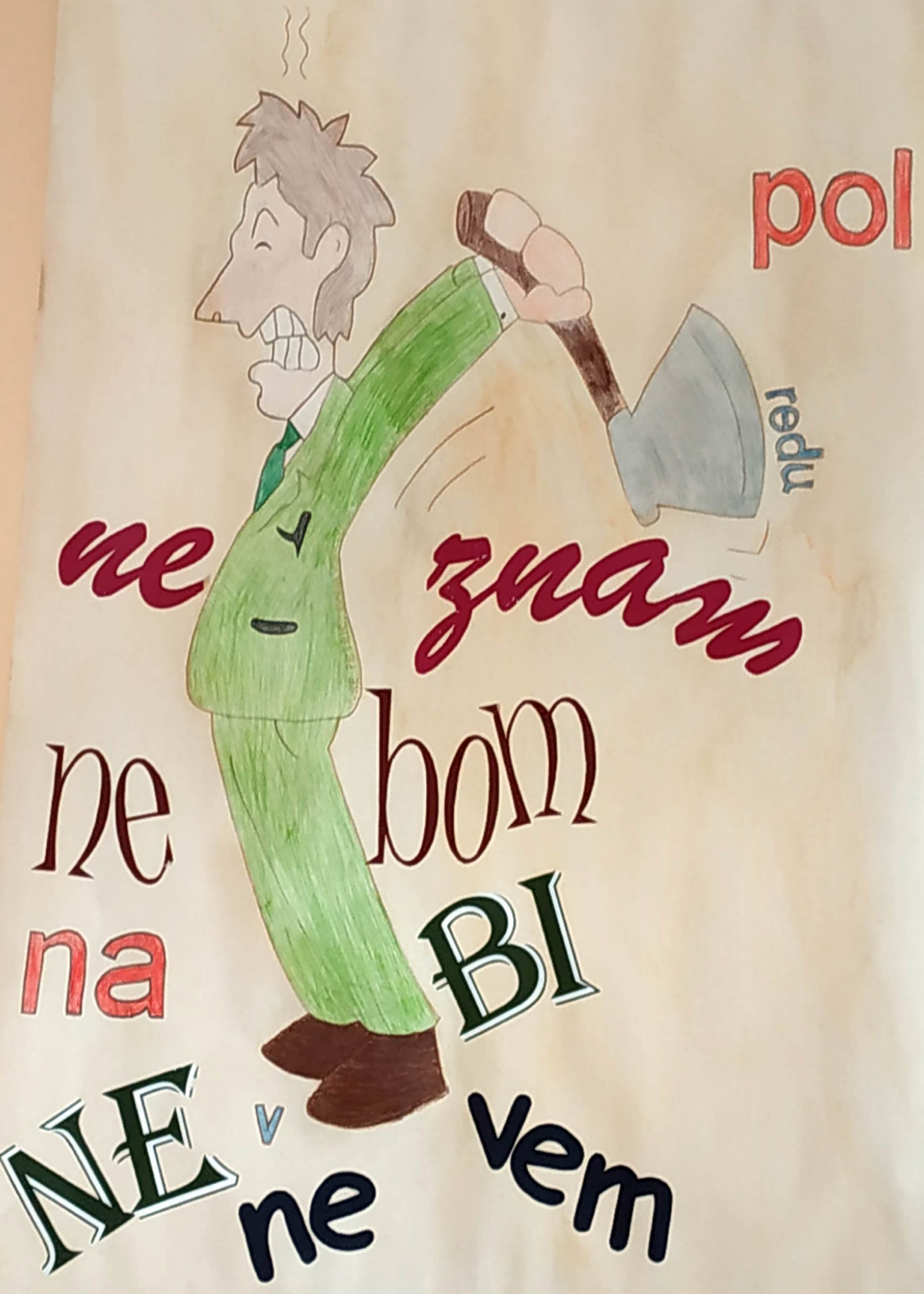




\title{
Božič s priredjem in podredjem
}

\author{
MOJCA JERALA - BEDENK
}

\begin{abstract}
Povzetek Skoraj vsako leto se zgodi, da me devetošolci, ko začnemo ponavljati in obravnavati skladenjske vsebine iz učnega načrta, podrezajo, češ zakaj se sploh morajo učiti stavčne člene ter odvisnike in priredja, kako jim bo to prišlo prav $\mathrm{v}$ življenju. Zato jih vedno poskušam prehiteti s pojasnilom, da je prav, da tisto, kar dnevno uporabljamo pri komunikaciji z drugimi, preverimo še teoretično. Kot bi se dvignili nad meglo, v kateri plava jezik, in ga začeli prepoznavati $s$ svojo čuječnostjo ter začeli sami sebe opazovati pri rabi jezika. Na ta način sem se lotila ponovitve skladnje v devetih razredih. Ponovitev obravnavanih vsebin smo začeli ravno $\mathrm{v}$ času pred božičnimi počitnicami, zato sem poiskala besedila, s katerimi bi učenci pridobili nove informacije na temo božiča, hkrati pa bi jih dopolnili $z$ zahtevanimi skladenjskimi strukturami in tako bi lahko opazovali njihovo uporabno vrednost.
\end{abstract}

Ključne besede: $\cdot$ skladnja $~ 9$. razred $\cdot$ dopolnjevanje besedila $\bullet$ tvorjenje besedila $\bullet$ filmska vzgoja $\bullet$

NASLOV AVTORICE: Mojca Jerala - Bedenk, Osnovna šola Vižmarje Brod, Ljubljana, Slovenija, e-pošta: jerala.bedenk.mojca@osbrod.si. 


\section{Iskanje besedil}

V času božiča zmeraj iščem besedila, s katerimi bi sprostila ure slovenščine tik pred počitnicami in ki bi se navezovala na božični čas. Učenci so takrat že vpeti v priprave na božične prireditve, na praznovanja v krogu družine, obdarovanje in prosti čas. Decembra se po televiziji predvajajo božični filmi, reklame nas bombardirajo z božičnimi nakupi, z radiev valovi božična glasba, zato so pogovori in besedila o božiču, ki bi jih uporabili za jezikovne vaje, še kako dobrodošli. Sobotna priloga Dnevnika ima na zadnjih straneh velikokrat zanimive lestvice, ki se aktualizirajo glede na čas in dogodke. V dveh izdajah sem tako našla članka Najpomembnejši bo ̌̌ičñ filmi useh časov (Štamcar 2016) in Najbolj trapasti božični filmi useh časov (Štamcar 2012). Kadar iščem besedila za devetošolce, poskušam izbirati in brati skozi njihove oči, da bi jih čim bolj pritegnila in morda spodbudila $\mathrm{k}$ nadaljnjemu raziskovanju, ne toliko jezikovnemu kot vsebinskemu. Ocenila sem, da sta ti dve besedili ustrezni, in se lotila priprave učne ure.

\section{Uvodna motivacija}

Učilnica je opremljena z računalnikom, projektorjem in belo tablo, ki služi tudi kot platno. Že pred začetkom ure sem pripravila predfilme (trejlerje) treh filmov: Cudovito življenje, Beli bo:̌ič in Gremlini. Ob začetku ure sem učence prosila, naj stole razporedijo, kot bi bili v kinodvorani, torej na sredino učilnice. $Z$ učenci se najprej pogovarjam o božiču in kaj je tisto, kar nas ves čas opominja, da je božični čas. Učenci omenijo tudi filme. Spodbudim jih, da mi povedo, katere filme običajno predvajajo v tem času in kolikokrat so jih že videli (npr. Sam doma). Tako se razvije pogovor o takih in drugačnih filmih. Ob tem jim lahko pokažemo tudi lestvico »najbolj trapastih božičnih filmov« ali pa nanjo opozorimo in upamo, da si jo bodo ogledali sami. Napovem oglede treh predfilmov in jih hkrati opozorim, da je današnja ura namenjena ponovitvi jezikovnega znanja, in sicer ponovitvi priredij in podredij. Nato si ogledamo predfilme. Vsi trije filmi so običajno učencem neznani. Po ogledu poslušam njihove komentarje, ocene in kritike, nato pa se lotimo ponovitve priredja in podredja. 


\section{Podredja}

Učence prosim, da v parih ponovijo vrste podredij in priredij, vprašalnice in veznike. Nato se vrnejo za svoje mize in se lotijo delovnega lista (priloga). Besedilo je skrajšano in prirejeno, da služi namenu, to je da učenci $\mathrm{v}$ besedilo vstavljajo manjkajoče odvisnike, pri tem pa jih vodijo vprašalnice ali vezniki. Ko končajo, se z listom odpravijo po razredu in pri še dveh sošolcih preverijo rešitve ter se odločijo za najboljšo možnost, ki jo pridejo napisat na tablo. Pri tem dobimo pet ali šest rešitev, ki jih primerjamo z originalnim besedilom. Ugotavljamo, kateri odvisnik se je najbolj približal originalu.

\section{Priredja in podredja}

Učencem razdelim še delovni list 2, na katerem sem uporabila tri Garfieldove stripe o božiču. Besedilo v oblačkih je sicer v angleščini, vendar za nalogo, ki sem jo dala učencem, to ni pomembno. Učencem sem dala naslednje navodilo:

Izberi si eno od treh zgodbic v stripu. Rąširi jo v besedilo tako, da boš v njem vsaj enkrat uporabil vsa priredja in vse odvisnike. Poimenuj jïh.

Naloga ni enostavna. Učenci so namreč morali ob tem, da so sledili zgodbi in strip razširili v logično in vsebinsko ustrezno besedilo, paziti tudi na to, da so uporabili vsa podredna in priredna razmerja, torej je to zahtevalo tudi teoretično znanje vseh vrst priredij in podredij.

Ker je v šoli zmanjkalo časa, so besedilo napisali za domačo nalogo. Naslednjo uro so besedila oddali in ob tem označili izbrani strip. Nastala so zanimiva besedila. Nekateri učenci so strukture označili tako, da so nad njih napisali poimenovanja, nekateri so podredja obarvali z eno, priredja pa z drugo barvo, nekateri pa enostavno niso označili ničesar in so pustili učiteljici, da preveri svoje znanje. ;) 


\section{Primer besedila: Garfieldovo božično darilo}

Ko se je Garfield zbudil, je ura odbila polnoč. Čeprav je bil zaspan, je šel v kuhinjo po nekaj hrane in pijače. Na poti po stopnicah mu je spodrsnilo, kot da bi bil na ledu. Kamor je pogledal, povsod je videl zvezde. Šele ko se je končno pobral, se je spet zavedel, kje je. Ker je padel na zadnjico, ga glava ni bolela. V kuhinji je iz hladilnika vzel torto in hitro popil požirek mleka. Ne le da ga je popil, tudi polil ga je. Ni se mu ljubilo pobrisati tal, pa je vseeno vzel krpo in počistil za seboj. Na poti v spalnico je moral skozi dnevno sobo, torej je šel tudi mimo novoletne jelke. Če ne bi prižgal luči, ne bi videl darila pod njo. Ni vedel, ali naj pogleda, komu je namenjeno, ali naj gre nazaj spat. Radovednost mu ni dala miru, zato je prebral napis na darilu. Ugotovil je, da je darilo zanj. Odprl ga je in zagledal uro, o kateri je že dolgo sanjal. Kdor mu je kupil to darilo, je dobro poznal njegove želje. Uro je ponovno zavil, da ne bi razočaral gospodarja. Mirno je odšel spat, saj je vedel, da bo zjutraj obdarovan.

(E. K., 9. razred, 2017/18)

\section{Sklep}

Že nekaj časa si prizadevam učencem dokazati, da jezikovni pouk ni nič drugega kot to, kar oni dnevno uporabljajo med komunikacijo, le da je praktična raba njihovega pogovornega vsakdana prestavljena $\mathrm{v}$ teorijo. Zato rada poiščem članke iz dnevnega časopisja ali iz mladinskih revij (npr. PIL), da učenci prepoznajo, da jezikovne vsebine, ki jih obravnavamo pri urah slovenščine, niso zaprte samo v učilnici slovenščine, pač pa hodijo z njimi, tudi ko niso več pri pouku. Učitelji ugotavljamo, da so učenci na jezik in pravopis dejansko pozorni večinoma le pri slovenščini. Že ko gredo v drugo učilnico k drugemu predmetu, npr. h geografiji, pozabijo na pravopisno normo; tudi pri tvorbi stavkov, ko bi lahko pokazali znanje in rabo raznolikih jezikovnih struktur, se ne potrudijo dovolj. Učitelji imamo občutek, da so vsebine posameznih predmetov, tako tudi vsebine jezikovnega pouka, zaklenjene $\mathrm{v}$ posamezne predalčke, ki se odprejo samo takrat, ko so učenci pri uri tistega predmeta. Slovenščini bi bilo treba nameniti več pozornosti tudi pri vseh ostalih predmetih, saj je cilj šolanja povezovanje in ne predalčkanje znanja. In morda bi bilo prav, da pri ocenjevanju znanja izgubijo kakšno točko tudi zaradi malomarnosti pri zapisih (ali pa jo pridobijo $\mathrm{v}$ primeru skrbnega zapisa), česar pa učni načrti posameznih predmetov ne dovoljujejo. 


\section{Viri}

Miha ŠTAMCAR, 2012: Najbolj trapasti božični filmi vseh časov. Dnevnik (8. 12. 2012). Dostop 11. 3. 2019 na: https:/ /www.dnevnik.si/1042566739

Miha ŠTAMCAR, 2016: Najpomembnejši božični filmi vseh časov. Dnevnik (24. 12. 2016). Dostop 11. 3. 2019 na: https://www.dnevnik.si/1042757644

It's a wonderful life, 1946: Dostop 11. 3. 2018 na:

https://www.youtube.com/watch?v=LJfZaT8ncYk

White Christmas, 1954: Dostop 11. 3. 2019 na: https://www.youtube.com/watch?v=3n3-UtakD3I

Gremlins, 1984: Dostop 11.3. 2019 na:

https://www.youtube.com/watch?v=XBEVwaJEgaA

Priloga: Delovni list 
Delovni list

\section{NAJPOMEMBNEJŠI BOŽIČNI FILMI VSEH ČASOV}

Prihaja najlepši čas v letu in (Kljub čemu?)

so se vsi dobro pripravili na nakupovalno mrzlico. Eden od glavnih krivcev za razvoj nakupovalnega Božička je Haddon Hubbard iz Michigana, ki . Podoba se je ujemala $z$ barvami Coca-Cole, njegov Božiček je bil rdečeličen in prijazen bajsi, ki

Zgodovina ameriških božičnih filmov je še nekaj let mlajša. Različni viri govorijo o različnih filmih, ki so začeli s to tradicijo. Najstarejši je bil Christmas Carol iz leta 1938, posnet po kratki Dickensovi Božični zgodbi, ki pa še nima

Oglejmo si tri najpomembnejše božične filme, ki so bili izbrani na podlagi kombinacije spletnih lestvic, prodaje in ocen kritike.

\section{1. ČUDOVITO ŽIVLJENJE (It's a Wonderful Life), 1946, Frank Capra}

Gre za romantično zgodbo o Georgeu Baileyju, lastniku male podružnice posojilnice, ki

ker ga $\mathrm{v}$ to potisne neizprosna in pokvarjena velika banka. Bailey se na zasneženi božični večer odpravi proti mostu, (S kakšnim namenom?) , vendar , ki zbere vse meščane, ki jim je Bailey pomagal in mu ponudijo pomoč. Film se za Baileyja zaključi ob božični jelki ne samo $\mathrm{v}$ objemu družine, ampak tudi $\mathrm{s}$ . Prislužil si je pet nominacij

za oskarja, (protivno priredje) . Štejejo ga za

osmi najbolj romantični film vseh časov, (sklepalno priredje) 


\section{BELI BOŽIČ (White Christmas), 1954, Michael Curtiz}

To je bil najbolj prodajani film leta, (navedi vzrok)

Zapel jo je Bing Crosby. V zgodbi zmešnjav, plesa in popevk nastopata Bing Crosby in Danny Kaye, ki sta na začetku vojaka, ki praznujeta božič na fronti v Evropi. Po mnogih peripetijah se ob vrnitvi domov v ZDA ob koncu filma zaljubita in film se konča srečno in pričakovano, in sicer (pojasni)

\section{GREMLINI (Gremlins), 1984, Joe Dante}

Pod producentskim vodstvom Stevena Spielberga, ki , je nastala ena najprijaznejših grozljivk vseh časov. Film, ki , se dogaja v majhnem mestu v času božiča, ko Billy dobi za darilo simpatično eksotično živalco. A njeni povampirjeni potomci postanejo prava mora za prebivalce mesta. Zadevo glavna igralca nekako obvladata, (nadaljuj z dopustnim odvisnikom)

Film si je prislužil tudi nadaljevanje. 


\title{
Mladostniški sleng $\mathrm{v}$ manjših interesnih skupinah
}

\author{
EVA LAJEVEC
}

Povzetek Pri obravnavi socialnih zvrsti v okviru gimnazijskega jezikovnega pouka je nastal korpus dijaških slengizmov, ki ga predstavljam v tem prispevku. Nabor enot se sicer ne more postavljati s svojim obsegom, je pa dragocen zato, ker so si ob njem mladostniki sami začeli zastavljati pomembna vprašanja, ki vodijo $\mathrm{k}$ nadaljnji jezikovni (pa tudi psihološki) razpravi. Ob dijaškem razmišljanju, kako velika mora biti skupina najstnikov, da razvije svoj prepoznavni sleng, kateri jezik najbolj vpliva na tvorbo novih slengizmov, kje se je na tej poti izgubila mladostniška izvirnost in kako te slengizme sploh zapisati, so se razvile izredno dejavne šolske ure.

Ključne besede: • socialne zvrsti • slengizem • mladostniški sleng • družinski sleng • pomensko polje $\bullet$

NASLOV AVTORICE: Eva Lajevec, Gimnazija Želimlje, Škofljica, Slovenija, e-pošta: eva.lajevec@zelimlje.si. 


\section{$1 \quad$ Uvod}

Dijaki Gimnazije Želimlje so posebna skupina mladostnikov in govorcev slovenskega jezika: kljub temu da je šola sorazmerno majhna (302 dijaka), trenutno prihajajo iz kar sedemdesetih slovenskih občin, poleg tega pa skoraj sedemdeset odstotkov dijakov med tednom živi v dijaškem domu. To pomeni, da želimeljski mladostniki usklajujejo govorico govornega okolja, iz katerega prihajajo, z novim okoljem, $\mathrm{v}$ katerem preživijo največ svojega časa in $\mathrm{v}$ katerem se tudi sicer najintenzivneje izražajo.

Prispevek je nastal zaradi radovednosti, kako obsežna je njihova prilagoditev, in ob predvidevanju, da je zaradi dialektalne raznolikosti jezikovna prilagoditev posameznega dijaka večja kot zgolj pri prehodu iz domačega narečja $\mathrm{v}$ pokrajinski pogovorni jezik. Ob pregledu izrazov, ki jih naši dijaki navajajo in prepoznavajo kot tipične slengizme, skušam predvsem odgovoriti na vprašanje, ali ti mladi med tednom dejansko ustvarjajo popolnoma novo jezikovno okolje s svojimi lastnimi zakonitostmi.

Ideja za to razmišljanje se je pojavila, ker dijaki pri obravnavi slenga vsako leto poročajo, da njihovi nekdanji sošolci iz osnovne šole govorijo bistveno drugačen sleng kot oni. Razlaga za ta pojav se je zdela hitra in preprosta: dijaška skupnost naše šole in dijaškega doma, $\mathrm{v}$ katerem bivajo, je ravno prav majhna in zaprta, da njeni pripadniki tvorijo svoj lastni sleng. ${ }^{1}$

\section{$2 \quad$ Kaj je sleng?}

\subsection{Uradna definicija jezikoslovcev}

Jože Toporišič v svoji slovnici kot tipično slengovske značilnosti navaja nekonvencionalnost, močno spolno zainteresiranost, upiranje vsakršni urejenosti, še posebej družbeni, podiranje tabujev, pretiravanje in objestnost, hitro menjavanje tega, kar je modno, in zato večno nova poimenovanja vsega erotičnega in

\footnotetext{
${ }^{1}$ Vse slengizme, ki so kot ilustrativno gradivo v ležečem tisku zapisani v tem prispevku, so navedli naši dijaki pri jezikovnem pouku o interesnih zvrsteh jezika. Izbrani so samo tisti primeri, ki nazorno podprejo posamezno poglavje. Namen prispevka namreč ni slovaropisni, ampak diagnostično-didaktični - morda v njem kdo od kolegov dobi idejo ali gradivo za zanimivo uro jezikovnega pouka.
} 
seksualnega, vsega, kar telo sprejema vase, duševnih in čustvenih stanj, družbenega uveljavljanja in značajskih lastnosti ljudi (Toporišič 2000: 25).

Velemir Gjurin je s svojim člankom Interesne govorice sleng, žargon, argo preučevanju slenga postavil terminološke in tipološke temelje. Poudarja, da sleng kot neformalno različico jezika poraja predvsem želja, da nekaj povemo na nov, morda presenetljiv način - zato je za sleng značilna predvsem ekspresivnost oziroma afektacija. Tej osnovni definiciji dodaja tudi spoznanje, da sleng določa predvsem njegov specifični besednjak, ki je sestavljen iz novotvorjenk ter starih izrazov z novim oziroma preobrnjenim pomenom (Gjurin 1974: 65).

V zadnjem času se s slengom in z njegovim zapisovanjem na platformah družabnih omrežij ukvarja Maša Rolih. Opozarja predvsem na značilnosti zapisanega slenga, v katerega vdirajo tujejezični in dialektalni elementi in ki je podrejen izraziti ekonomičnosti jezika, kar se kaže v pogosti rabi čustvenih ikon in ostalih nebesednih izrazov čustvovanja (Rolih 2014).

\subsection{Kako sleng pojmujejo dijaki?}

Dijaki na uvodno vprašanje, katere slengizme poznajo in uporabljajo, vsako leto najprej odgovorijo z besedama ful in kul, potem pa se možganska nevihta na hitro umiri. Zanimivo je, da so še nedolgo tega ob rahli profesorjevi spodbudi začeli naštevati žargonske slengizme s področja šole, ki jih najbolj zaposluje (kol, šut, zakoličiti, zašutirati, kema, kemarca) - dandanes pa se iz njih usuje nepregledna množica novodobnih tvorjenk, povezanih z obvladovanjem medmrežja in družabnih omrežij (selfi, mesic, mim, lajkati, komentati).

Ko jih opozorim, da je sleng govorica posebnih skupin govorcev, ki skušajo že poimenovano predmetnost poimenovati na čim izvirnejši način, običajno naletim na zadržanost, češ da njihove običajne slengovske besede niso nič posebnega. To zadrego premostimo na dva načina: z iskanjem najbolj zabavnih besed, ki jih uporabljajo oni ali njihovi mladostniški prijatelji, in pa s pojasnilom, da sleng uporabljajo celo njihovi stari starši, o čemer bomo govorili v nadaljevanju. 


\section{$3 \quad$ Vrste slenga}

Po Gjurinu obstajajo štiri vrste slenga, od katerih je (že po avtorjevem mnenju) ena vprašljiva (Gjurin 1974: 72).

\subsection{Otroški sleng}

Pri tej vrsti slenga morda lahko govorimo o dveh podvrstah, in sicer glede na starost njunih govorcev.

a) V prvo skupino bi lahko uvrstili specifično govorico najmlajših otrok, ki šele ustvarjajo svoj besednjak in jezikovni sistem. Ta je v najzgodnejši otroški dobi pogojen $\mathrm{z}$ otrokovimi artikulacijskimi, ubesedovalnimi in upovedovalnimi zmožnostmi, zato so zanj značilne jezikovne napake na vseh jezikovnih ravninah. Najbolj tipično je menjavanje vrstnega reda glasov (̌̌evla namesto ̌̌elva, kepač namesto kečap, špenica namesto p̌renica, kajbovci namesto kavbojci, iæqdiflikiciran namesto diskvalificiran), napačno izgovarjanje posameznih glasov $\mathrm{v}$ besedi - zaradi težke izgovorljivosti določenih soglasniških sklopov ali zato, ker jih narobe slišijo (fiknes namesto fitnes, komfri namesto pomfri). Ta slengovska podvrsta je najbolj vprašljiva, saj ji manjka namernost - otroci teh napak ne zagrešijo namenoma oziroma zato, da bi bili izvirni. Razlog, da to govorico malčkov sploh omenjamo, je dejstvo, da vsaj nekatere njene pojavnosti ostajajo v otrokovem govoru tudi pozneje, ko ta že prepozna svojo napako (o tem v točki 3.2).

b) Druga podvrsta otroškega slenga po Gjurinu zajema tipično govorico starejših otrok, ki je pogosto zaznamovana z zmerljivkami in zafrkljivkami, pretiravanji in skatološkimi izrazi (Gjurin 1974: 72). Pri tej vrsti slenga si že Gjurin zastavlja vprašanje, ali resnično ustreza definiciji slenga $\mathrm{v}$ tisti točki, ki pravi, da sleng nastaja hote in v želji po izvirnem poimenovanju nečesa, kar že ima svoje ime. Avtor pravi, da je za tvorbo novih slengizmov potrebna »jezikovna samozavest«, ki je pogojena $z$ razvitejšo zavestjo o jeziku in njegovih zmožnostih (Gjurin 1974: 72). 


\subsection{Družinski sleng}

$\mathrm{Na}$ podlagi zgoraj omenjenih nehotenih napak (točka a) se zelo pogosto oblikuje družinski sleng; starejšim družinskim članom se otroške prenovitve besed zdijo tako prikupne, da jih sprejmejo v svoj družinski besednjak. Ta pojav je širši, kot si morda predstavljamo; dijaki resnično uživajo, ko se spominjajo besed, ki so jih razumeli samo v ožjem družinskem krogu in so jih ravno zato z velikim veseljem uporabljali tudi v širšem diskurzu. Nekaj izsledkov tovrstnih jezikovnih pogovorov z dijaki je zapisanih $\mathrm{v}$ spodnjem razdelku, vendar bi si ta tematika zagotovo zaslužila samostojno obravnavo.

\section{OHRANJANJE NEHOTENIH NAPAK MALČKOV}

$$
\begin{aligned}
& \text { graža (= garaža) } \\
& \text { luka (= luknja) } \\
& \text { trontolin (= trampolin) } \\
& \text { barbinton (= badminton) } \\
& \text { čalapinke (= palačinke) } \\
& \text { kamaroni (= makaroni) } \\
& \text { budala (= nabodala) } \\
& \text { marmarelična marmelada (= marelična marmelada) }
\end{aligned}
$$$$
\text { mazoneza (= majoneza) }
$$$$
\text { mama jeza (= majoneza) }
$$$$
\text { nama nama neza (= majoneza) }
$$$$
\text { clovek na jezuse (= človek, ne jezi se) }
$$

\section{OTROŠKI ALI POOTROČENI IZRAZI}

$$
\begin{aligned}
& \text { pitatl (= Pink Panter) } \\
& \text { rolčki (= rolerji) } \\
& \text { nička (= risanka) } \\
& \text { vigolire (= vžigalice) } \\
& \text { lubica (= lubenica) } \\
& \text { opica (= jopica) }
\end{aligned}
$$




\section{POIMENOVANJA PO ANALOGIJI}

medvedki (= kosmiči)

brustki (= kosmiči)

kuglce (= čokoladne kroglice, ki jih stresemo v mleko)

cokoladni sokec (= čokoladno mleko)

borovnickee (= borovničev sok)

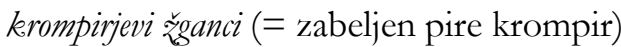

fertik drek (= makaroni z mletim mesom in omako)

kinder jajcek (= majhen avtomobil, dvosed)

nulta (= najnižji del hladilnika)

\section{DUHOVITE JEZIKOVNE IGRE}

morski deklc (= morska deklica moškega spola)

furcivoda (= kriza)

štručkava salama (= sirova štručka)

tetec (= stric)

pomivanka (= gobica za pomivanje)

smajlo (= sebek, posnetek samega sebe)

rukanica (= makadam)

roฆ̌licarna (= cvetličarna)

sračapela $(=$ stračatela $)$

SLABŠALNI, NIŽJEPOGOVORNI, VULGARNI IZRAZI

kuəlc (= pes)

SVOJEVRSTNE ANTONOMAZIJE

janički (= človeške figurice $\mathrm{v}$ legokockah; po sosedu Janiju)

Matija bo prišel (= strašljivka, če otroci niso pridni; po vaškem beraču)

Rupe/iti v Rupe (= neprijeten, temačen kraj/biti kaznovan, če nisi priden) 


\section{DRUGO}

rima izglave (= nekaj, kar je samo približno napisano v verzih, posrečeno, vendar nesmiselno)

pet minut za novo pesmico ( = kratek popoldanski počitek)

srednja soba (= soba, kjer so shranjene nekoristne, odvečne, malokrat uporabljene stvari)

\subsection{Mladostniški sleng}

Ta vrsta slenga je njegova najbolj reprezentativna vrsta, saj intenzivno izpolnjuje vse točke osnovne definicije slenga - mladostniki želijo hkrati pripadati neki interesni skupini in iz nje tudi izstopati, kar se kaže tudi v njihovih jezikovnih izbirah. Poleg izrazite težnje k originalnosti je za mladostniški sleng značilna velika neobstojnost. Ne samo, da današnji najstniki ne poznajo Gjurinovih slengizmov ali slenga svojih staršev - na naši gimnaziji opažamo, da kljub majhnosti šole dijaki ne poznajo besedišča prejšnje generacije; še več, pogosto se čudijo slengu samo eno leto starejših dijakov. Zato se je zastavilo vprašanje, ki je še dodatno spodbudilo ta prispevek: kaj torej vpliva na razvoj dijaškega slenga, če se med seboj občasno ne razumejo niti pripadniki tako majhne skupnosti, kot je naša.

\subsection{1 Želimeljski sleng}

Dosedanja raziskava in pogovori z dijaki glede značilnosti, ki zamejujejo želimeljski sleng in ga ločujejo od splošnega slovenskega, žal ni dala jasnih odgovorov, vendar to ni nič presenetljivega - sleng je izredno živa in hitro spreminjajoča se pojavnost, ki jo je že po definiciji težko sistematizirati. Splošni občutek dijakov, ki med tednom ne živijo $\mathrm{v}$ dijaškem domu in imajo zaradi svojih obšolskih dejavnosti redne stike $\mathrm{z}$ mladostniki, ki hodijo na druge ljubljanske srednje šole, poročajo, da »ljubljančani« uporabljajo še bolj angliziran, ekspresivnejši in vulgarnejši sleng.

\subsection{2 Želimeljski sleng manjših interesnih skupin}

Tisto, čemur se da v resnici lažje slediti, pa je sleng manjših skupin, po navadi skupine prijateljev ali prijateljic znotraj posamezne vzgojne skupine, za katere so posamezni slengizmi značilni oziroma so dijaki po njih prepoznavni. Spodaj navajam samo nekaj vzorčnih primerov. 
s'qui (= hočem objem)

piu piu piu (= računalnik)

A si ti mal ferukt al kaj? (= Ali si zmešan?)

Venulija (= ime točno določene lončnice, sicer pa beseda, ki jo nekdo vzklikne, kadar kdo v njegovi bližini komu kaj šepeta ali na splošno česa noče povedati; ko jo nekdo izreče, mu dotični mora povedati svojo skrivnost)

brlev (= neumen, slep)

sesati (= poljubljati (se))

seansa (= nekaj minut za jokanje)

minuta (= na hitro poveš nekaj, kar te moti, in tega ne sme nihče komentirati)

ti si mi $\operatorname{dovolj}$ (= rad te imam)

prežokati (= zmasirati)

drevež = drevo, ki je revež

Yaaa! (= pozdrav; izvira iz korejskega nazivanja mlajših od sebe)

\subsection{Splošni sleng}

Zastavlja pa se tudi vprašanje, ali obstaja sleng, ki bi ga razumeli vsi ali vsaj velika večina slovenskih govorcev. Če se spomnimo že omenjenih slengizmov ful in kul, je odgovor seveda pritrdilen. Dijaki ob tem razmisleku spoznajo, da nekaj »zimzelenih« slengizmov uporabljajo vsaj njihovi starši, če že ne stari starši, saj so vseprisotni in očitno dovolj zanimivi, da jih uporabljajo tudi današnji mladi (npr. kifeljc, brez. veže, piflar, luzere, prfoks, bluriti, špricati; mala malca).

\section{$4 \quad$ Presoja slenga po jezikovnih ravninah}

Gjurin v članku o interesnih govoricah pravi, da je sleng v glasoslovju, oblikoslovju, skladnji in intonaciji enak knjižnemu jeziku (Gjurin 1974: 66). Če se je v svojih ostalih trditvah izkazal za preroškega (sploh ko je napovedal eksponenten porast vpliva angleščine), moramo na tej točki priznati, da je 35 let družbenega in tehnološkega razvoja prineslo nenadejane spremembe tudi na področju slenga. Te se pojavljajo tako na glasoslovni kot tudi na oblikoslovni in skladenjski jezikovni ravnini. 


\subsection{Glasoslovje}

Angleščina je opazno vdrla že v mladostniški sleng sedemdesetih let prejšnjega stoletja, ko je bil Gjurinov članek napisan, danes pa lahko rečemo, da ga že skoraj popolnoma obvladuje. Ta prevlada je tako močna, da vpliva tudi na izgovor slengizmov angleškega izvora. Tvorjenko followati ('slediti nekomu in njegovim objavam na družabnih omrežjih') bi po slovenskih pravorečnih pravilih morali izgovarjati z zobnoustničnim [v] - večina dijakov ga tako tudi izgovarja, vendar se število govorcev, ki ga izgovarjajo z dvoglasniško (torej angleško) različico, opazno povečuje.

Ta pojav je še toliko trdnejši pri čedalje številčnejših angleških besedah, ki v slengu naših mladostnikov pristanejo kar v citatni obliki, npr. awesome, awkward, annoying. Pri izgovoru omenjenih besed še nisem slišala najstnika, ki bi se trudil, da bi njihovo izgovorjavo poslovenil - to bi po njihovem razumevanju pomenilo, da ne znajo dovolj dobro govoriti angleško. Nekoliko drugačna zgodba se pokaže pri besedah, ki vsebujejo $r$ (kripi, skern), ali tistih, v katerih je samoglasnik $i$ v angleščini kratek (šiti, sik) - te namreč izgovarjajo poslovenjeno in zdi se mi, da se tega niti ne zavedajo. ${ }^{2}$

\subsection{Oblikoslovje}

$\mathrm{S}$ prihodom in ustalitvijo zgoraj omenjenih citatnih besed se v slovenskem slengu povečuje delež nesklonljivih besed, predvsem pridevnikov - je pa res, da so jim že davno tega pripravili prostor leksemi tipa video rekorder in audio kaseta.

\subsection{Skladnja}

Mladostniki ne poskušajo biti izvirni samo na pomenski ravni in $\mathrm{v}$ frazeologiji, ampak skušajo (vsaj občasno) predrugačiti tudi zborno skladnjo. Tipičen primer je slengovski frazem iti na tablo ('iti reševat primer, ki je zapisan na tabli'), v katerem je raba predloga drugačna kot $v$ knjižnem jeziku. Za trenutni želimeljski sleng je značilno tudi izražanje tipa štumfi na kivije in majïca na rožice ('nogavice, porisane s kiviji', 'majica iz rožičastega blaga').

\footnotetext{
${ }^{2}$ Morda je zaznavanje te problematike podzavestno, saj se pri zapisovanju druge skupine besed mnogo večkrat pojavi zapis po izgovoru, ki se pri prvih besedah ne pojavi skorajda nikoli. Kaj več o tem tudi v poglavju 6.2.
} 


\section{$5 \quad$ Slengizmi glede na področje rabe}

Ko smo z dijaki raziskovali vzroke, zakaj mnogi ne poznajo nekaterih slengizmov, ki jih starejši dijaki iste šole uporabljajo povsem redno, smo prišli do zanimive ugotovitve, ki jo dijaki v svojem diskurzu baje opažajo že dlje časa - da je namreč tudi še tako majhna šola prevelika za poenoten sleng. Naši dijaki so namreč s pedagoškim procesom (tudi po pouku in izven šole, na primer na enotedenskih ekskurzijah in spoznavnih tednih) spodbujeni, da delujejo kot generacija. Še močneje pa na osnovanje slenga $z$ ožjim področjem rabe deluje razporejenost dijakov $v$ vzgojne skupine $\mathrm{v}$ okviru dijaškega doma $-\mathrm{v}$ teh skupinah se sproti ustvarja poseben besednjak, o katerem poročajo celo na ravni ene, dveh ali treh sob. Sploh dekleta so nagnjena $\mathrm{k}$ temu, da imajo kar nekaj besed in frazemov, ki so lastni zelo ozki skupini dijakinj in »dišijo« po skrivnem kodu oz. argoju. Vendar je pri tem treba poudariti, da to besedišče ni nastalo zaradi skrivnostnosti ali želje po nerazumljenosti, ampak iz čistega veselja po ustvarjanju nečesa lastnega - kar je osnovna značilnost slenga.

Po drugi strani pa so ravno fantje dveh vzgojnih skupin znani po svojem izrazito nemško zvenečem slengu. Verjetno je razlog za to nenavadnost $\mathrm{v}$ dejstvu, da imajo naši dijaki nemščino za enega najtežjih šolskih predmetov, ki se ga redno in zelo intenzivno učijo. Nemški pozdravi in fraze so se sprva pojavili nekoliko ironično oziroma v obupanem posmehu po celonočnem učenju, potem pa so v (prekomerni) rabi nemških popačenk začeli uživati in zato ta slengovska različica pri nas vztraja že več kot dve leti.

\section{Slengizmi glede na pomenska polja}

Smiselno in pričakovano je, da so mladostniki v svojem slengu najbolj tvorni na področjih, ki jim zaradi zanimanja in družbene nuje vzamejo največ časa. V grobem se slengizmi dotikajo predvsem šole, odnosov in vrednostnih izrazov, družabnih omrežij in tehnologije, ki je z medmrežjem in družabnimi omrežji povezana, ter z ostalimi hobiji.

Sploh na področju družabnih omrežij je bera slengovskih besed neizmerna, saj mladostniki za nastanek novega slengizma ne potrebujejo veliko energije: na sedanjiško osnovo (angleškega) glagola, ki kot besedna vrsta v tovrstnih slengizmih popolnoma prevladuje, samo dodajo nedoločniško obrazilo -ati, ki ga potem v živi rabi pregibajo po slovenski spregatvi. 
V okviru razmišljanja o pomenskih poljih, na katerih je želimeljski sleng najbolj plodovit, največjo nenavadnost predstavljajo slengizmi nemškega izvora - ti pokrivajo področja od navezovanja stikov (Guten Tag! Komm! Danke.) do osebne higiene (dušati se). Ker smo rekli, da gre za specifiko naše šole, kjer ima nemščina zares posebno mesto, lahko tovrstne slengizme mirno uvrstim na posebno podpodročje šolskega besednjaka.

\subsection{Pomensko polje šola}

Zanimivo je, da dijaki v zvezi s šolo vztrajajo pri besednjaku, ki so ga poznali že vsaj njihovi starši. Poimenovanja za negativno oceno (kol, bat, cvek, šut, šus, eins) in glagoli, ki izražajo njihovo neuspešnost pri ocenjevanju (zabiti, zakoličiti, cepniti, pocepati, zafrkniti, zaribati, rukniti, leteti), delujejo izredno klasično. Prav tako niso iznašli ničesar novega pri poimenovanju predmetov: še vedno vztrajajo pri krnih slova, fiza, kema, angla ipd. (prim. tudi Voršič 2018), pri čemer so še najbolj nenavadna poimenovanja zgodla, ki bi po tem istem postopku vmesne krnitve morala biti zgoda (iz zgoderina), pa se najbrž priliči angli; potem mata, ki ima zelo pogosto različico [mata] (ta polglasniški izgovor je tako izrazit, da besedo pogosto zapisujejo kar mta), ter bajla s svojo angleško izgovorjavo, ki ima svojo daleč najpresenetljivejšo različico bigla, za katero dijaki ne vedo, od kod je prišla; opaziti je mogoče le to, da jo v največjem deležu uporabljajo dijaki s severozahoda Slovenije. Majhna skupina dijakov razredni uri pravi ruščna, k čemur jih napeljuje kratica RU.

$\mathrm{Na}$ področju, kjer bi se lahko izkazali najbolj, to pomeni pri poimenovanju profesorjev, večinoma uporabljajo izpeljanke iz poimenovanj predmetov (slovarca, latarca, bajlarca), le pri najbolj prepoznavnih profesorjih uporabljajo krne njihovih imen ali priimkov (Vrbo za Vrbovška, Emro za Emeršiča, Benď̌o za Benjamina); šolska čistilka je edina, ki je dobila metaforičen vzdevek.

Trenutno najbolj zanimivi izrazi s področja šole so trojka fazan - turbo fazan - nitro fazan, ki pomenijo 'dijak prvega letnika', 'dijak, ki pade in ponavlja prvi letnik', 'dijak, ki že drugič pade prvi letnik in zapusti šolo'. Za enega najbolj popularnih slengizmov zadnjega časa pa gotovo lahko razglasimo spodbudo Maš to! 


\subsection{Pomensko polje družabna omrežja}

Področje medmrežja in družabnih omrežij je področje, kjer se tako starši in psihologi kot tudi jezikoslovci boleče zavedamo, da nas stvari prehitevajo. Razvoj tehnologije je tako hiter, da mu z ustreznim slovenskim izrazoslovjem preprosto ne moremo slediti, dijaki pa (skoraj brez izjeme!) v iskanju slovenskih izrazov sploh ne vidijo smisla. Še več: tudi v primerih, ko je strokovna in splošna javnost pohitela in ustvarila slovenske ustreznice nekaterim najpogostejšim izrazom (na primer všeckeati namesto lajkati, sebek namesto selfi, čivk namesto tvit), se našim dijakom zdi njihova uporaba nesmiselna, besede same po sebi pa smešne in bizarne. Mnogi jih celo ne poznajo; tisti redki, ki so jih sploh kdaj uporabili, pa so jih uporabili izključno v norčevanju.

Tako njihov govor preplavljajo izrazi lajkati, tvitati, subskrajbati, akseptati, guglati, poustati, snepati, tegati, šerati, sejvati, shekati, strimati, sinati, riektati, diemati ipd. Že na prvi pogled je besedotvorni postopek pri prenosu iz tujega jezika ves čas popolnoma enak in dijakom se zdi, da so s tem, ko so tujemu glagolu dodali slovenski končaj in ga zato lahko spregajo po slovenskem spregatvenem vzorcu, za ohranjanje slovenskega jezika naredili dovolj. Kako daleč so nam zadeve ušle, priča glagol komentirati, ki je v slovenskem besedišču prisoten že lep čas. Prevzet je bil v času, ko smo glagole tujega izvora prevzemali z nemško zvenečim končajem -irati (kot npr. telefonirati, mikroskopirati), kar naenkrat pa je postal nemoden - današnji najstniki za pisanje komentarjev na družabnih omrežjih uporabljajo glagol komentati, torej glagol, ki ima enak pomen kot komentirati, le da je njegova oblika uniformirana oziroma usklajena z vsemi ostalimi, ki so našteti zgoraj.

Pri tovrstnih slengizmih se odpre vprašanje zapisovanja, ki ne more dobiti zadovoljivega odgovora. Sleng je že po definiciji nestandardizirana različica jezika; ob tolikšni prevladi tujih besed in besed, ki so poslovenjene samo na silo, vlada pri zapisovanju popolna anarhija. Tudi mladostniki sami priznavajo, da za zapisovanje nimajo nikakršnih pravil in da opažajo, da niso usklajeni sami s seboj. Med dijaki sem izvedla kratko empirično raziskavo, s katero sem preverjala njihovo zapisovanje: med njimi ni bilo niti enega, ki bi uspel v polnosti vztrajati pri citatnem zapisovanju. Nekaj več jih je zmoglo uspešno posloveniti veliko večino glagolov in samostalnikov angleškega izvora, le pri pridevniku magic (meď̌ik) so imeli vsi po vrsti zavoro, ki jim besede ni pustila zapisati poslovenjeno. Vsi ostali so brez jasne orientacije križarili nekje vmes in ustno razložili, da se pri zapisovanju ravnajo zgolj po občutku. 
7

Sklep

Sleng je živ organizem, ki se stalno in zelo hitro spreminja - vendar ni samo spremenljivka v času, ampak tudi v prostoru. Slovenija ni dovolj majhna, da bi imela enoten mladostniški sleng; na naši šoli celo ugotavljamo, da je okolje tristotih dijakov preširoko, da bi imelo enovito govorico. Nekaj $\mathrm{k}$ temu pripomore različno geografsko in družinsko okolje dijakov, ki prihajajo $\mathrm{k}$ nam iz vseh slovenskih pokrajin ter se morajo tako in drugače prilagoditi novi diskurzivni skupnosti; nekaj doda še oddaljenost šole od kulturnega in družabnega dogajanja prestolnice in drugih večjih središč. Vseeno pa ta oddaljenost ni tako velika, da bi se naši dijaki lahko izognili pospešenemu vdoru tujejezičnih elementov $\mathrm{v}$ njihovo govorico in posledično oslabljeni izvirnosti pri kovanju lastnih izrazov, $\mathrm{s}$ katerimi bi zares ekspresivno, zanimivo in učinkovito izražali svoj odnos do sveta.

\section{Literatura}

Velemir GJURIN, 1974: Interesne govorice sleng, žargon, argo. Slavistična revïa 22/1, 65-81.

Maša ROLIH, 2014: Različni vplivi na jezik mladih. Jezikoslovni zapiski 20/1, 79-92.

Jože TOPORIŠIČ, 2000: Slovenska slovnica. Maribor: Založba Obzorja.

Ines VORŠIČ, 2018: O jezikastičnem jezik(ov)anju. Slovenščna na dlani 1. Ur. Natalija Ulčnik. Maribor:

Univerzitetna založba Univerze v Mariboru. 7-11. 


\title{
Frazeologija v očeh (prvo)gimnazijcev
}

\author{
TJAŠA MARKEŽIČ
}

\begin{abstract}
Povzetek Prispevek se osredinja na obravnavo frazemov pri pouku slovenščine $\mathrm{v}$ gimnazijskem programu. $\mathrm{V}$ prvem delu prikazujemo frazeologijo in frazeme $\mathrm{v}$ luči srednješolskih učbenikov in učnega načrta, $\mathrm{v}$ drugem pa se osredotočamo na uporabo pridobljenega znanja. Pri tem posebej izpostavljamo tiste frazeme, ki so dijakom najmanj poznani, in ugotavljamo, kateri tipi jezikovnih nalog $\mathrm{s}$ področja frazeologije gimnazijcem povzročajo največ težav. Opažamo, da se dijaki zelo zanimajo za to jezikovno ravnino in da se zavedajo pomena frazeologije $v$ vsakdanji jezikovni rabi, kar dokazujeta dve raziskovalni nalogi, ki sta bili $\mathrm{v}$ zadnjih letih na natečajih Mladi za napredek Maribora in Znanost mladini visoko uvrščeni in nagrajeni.
\end{abstract}

Ključne besede: • slovenski jezik $\bullet$ frazeologija $\bullet$ frazem $\bullet$ raziskovalna dejavnost $\bullet$ gimnazija $\bullet$

NASLOV AVTORICE: Tjaša Markežič, Prva gimnazija Maribor, Maribor, Slovenija, e-pošta: tjasa.markezic@prva-gimnazija.org. 


\section{Splošno o frazeologiji v slovenščini}

V sodobnem jezikoslovju frazeologija pomeni dvoje: je veda o frazeoloških enotah in hkrati skupek vseh tovrstnih enot (Toporišič 1973/74: 273). Govorimo lahko o proučevanju frazeologije s širšega ali ožjega vidika: širše proučevanje obsega jezikovne enote, katerih lastnosti sta stalnost in večbesednost, ožje proučevanje pa zajema tisto, kar ima ob navedenih značilnostih tudi frazeološki pomen, ki označuje nemotiviranost pomena večbesedne enote iz njenih sestavin (Jakop 2006: 18). Podobno definira frazem tudi Janez Keber (2011: 9), čigar Slovar slovenskih frazemov je pomemben mejnik v razvoju slovenske frazeologije. Toporišič (1973/74: 273) pa opozarja na problem poimenovanja osnovne frazeološke enote; ugotavljamo, da se je v slovenskem jezikoslovju uveljavilo poimenovanje frazem, ki ga dosledno uporabljajo tudi v naš prispevek vključena gradiva.

\section{Obravnava frazeologije v srednješolskih učbenikih}

Po učnem načrtu za gimnazije (Poznanovič 2008: 13, 35) dijaki v 2. letniku razvijajo poimenovalno zmožnost tako, da pred sprejemanjem besedil ali po njem predstavljajo pomen danih frazemov, sistematično nadomeščajo proste besedne zveze s frazemi in obratno ter razložijo frazem, predstavijo njegove ustrezne okoliščine in ga uporabijo v povedi. Primerjali smo tri učbenike, namenjene pouku slovenščine v gimnazijah in drugih strokovnih šolah v 2. letniku: Slovenšina 2: ₹ besedo do besede, Na pragu besedila 2 in Barve jezika 2.

Obravnava frazemov v učbeniku Slovenš̌ina 2: z besedo do besede se začne z navedenimi časopisnimi naslovi, ki vključujejo stalne besedne zveze, med katerimi je mogoče zaslediti frazeme (Koroška - kulinarična črna lisa Slovenije) ali njihove prenovitve ( mlad odšel s trebubom za ... そ̌ogo). Učbenik definira frazeme kot stalne besedne zveze $\mathrm{s}$ prenesenim pomenom, saj njihovega pomena ne moremo razbrati iz pomena besed, iz katerih so sestavljeni (npr. nastaviti komu ogledalo). Zanje je značilno, da imajo vedno enak pomen, ki se ga naučimo hkrati s posameznim frazemom. Frazemi so subjektivni, zato so še posebej značilni za praktičnosporazumevalna in publicistična besedila, oglase in umetnostna besedila; ne uporabljamo jih $\mathrm{v}$ uradovalnih besedilih, v strokovnih pa le, če želimo bralce pritegniti ali jim razumljivo ponazoriti abstraktno pravilo. Za frazeme je značilna stalnost oblike in pomena, zato jih ne moremo poljubno spreminjati (morda le zaradi vključevanja v sobesedilo). Frazeme, ki nimajo stavčne oblike, imenujemo rekla (npr. ostati pražnih rok), tiste, ki so že sami po sebi 
stavki, pa pregovori/rečenice (npr. Pǒ̌asi se daleč pride.). S pregovori je metaforično izražena življenjska resnica ali nauk, zato jih pri daljših besedilih najpogosteje uporabljamo v naslovih ali z njimi izpovemo sporočilo. Pregovori so značilni zlasti za subjektivna publicistična besedila in za nekatera umetnostna besedila, npr. basni. $S$ frazemi hitro pritegnemo pozornost; lahko jih delno preoblikujemo, da jih smiselno navežemo na temo besedila, delno pa pustimo frazeme nedotaknjene. Temu pravimo prenovitve frazemov (Vogel 2016a: 158-160).

Učbenik Na pragu besedila $2 \mathrm{v}$ začetku poglavja v krajše besedilo vključuje proste (npr. seznam živali) in stalne besedne zveze, med slednjimi tudi frazeme (npr. mala malica), dijake pa $z$ dodatnimi vprašanji usmeri $v$ obravnavo frazemov. $V$ nadaljevanju so frazemi definirani kot stalne zveze besed s pomenom, ki ni napovedljiv iz pomenov sestavin. Znova je poudarjena stalnost pomena in oblike, a slednjo lahko deloma spremenimo zaradi lažjega vključevanja v besedilo (npr. zaljubljen (a) do ǔses, nosi(l) glavo na prodaj). Tudi ta učbenik izpostavlja stavčnost in nestavčnost frazemov ter njihovo slogovno zaznamovanost. Poglavje omenja vedo, ki proučuje frazeme, torej frazeologijo, in frazeološki slovar ter frazeološko gnezdo v Slovarju slovenskega knjižnega jezika (dalje SSKJ). Za razliko od prvega pa ta učbenik opozarja tudi na primerjavo frazemov v slovenščini s tujejezičnimi frazemi (Križaj Ortar 2017a: 1315).

Učbenik Barve jezilka 2 uvaja obravnavo frazemov ob izhodiščnem neumetnostnem besedilu in vprašanjih, ki se navezujejo nanj. V posebni nalogi z ilustracijami od dijakov pričakuje, da ugotovijo, kateri frazem je prikazan (npr. hoditi kot maček okrog vrele kaše). Frazeme razlaga kot stalne besedne zveze s prenesenim pomenom, kar ponazori s primerom deklica za vse. Frazemi imajo določen pomen in obliko, zato jih ne moremo spreminjati, torej jim dodajati ali odvzemati besed, lahko pa npr. spregamo glagole $\mathrm{v}$ njih (npr. govoriti kitajsko $\mathrm{v}$ povedi uporabljamo tako, da glagol spregamo, torej Ali govorim kitajsko?). Tudi ta učbenik izpostavlja delitev na rekla (npr. Zardel je kot kuhan rak.) in rečenice/reke/pregovore (Ti očeta do praga, sin tebe čez. prag.). Zaradi slogovne zaznamovanosti niso primerni za rabo $\mathrm{v}$ vseh besedilih; pogosti so $\mathrm{v}$ reportažah, ocenah, komentarjih, reklamnih in umetnostnih besedilih. Poleg frazeološkega gnezda v SSKJ in Slovarja slovenskih frazemov pa učbenik omenja tudi zbirko Reki in pregovori na Slovenskem (Etbin Bojc) in spletno stran www.frazemi.net (Slemenjak idr. 2017a: 32-35). 


\section{Utrjevanje pridobljenega znanja}

\section{Pregled nalog po (samostojnih) delovnih zvezkih}

Pregledali smo tudi naloge $\mathrm{v}$ delovnih zvezkih za pouk slovenščine v 2. letniku gimnazij in srednjih strokovnih šol: Slovenšcina 2: ₹ besedo do besede, Na pragu besedila 2 in Barve jezikea 2. Ob pregledu zbranih nalog se vidi uresničevanje Bloomove taksonomije: prvotne naloge od dijakov pričakujejo poznavanje ter razumevanje snovi, uporabo in analiziranje, $\mathrm{v}$ nadaljevanju pa se že nanašajo na zmožnost sinteze in vrednotenja.

Začetne naloge v delovnem zvezku Slovenšina 2: z besedo do besede (Vogel 2016b) so usmerjene $\mathrm{v}$ dopolnjevanje frazemov (npr. lezeš kot ali $\mathrm{v}$ pripisovanje pomena k posameznim frazemom (npr. moker kot cucek - zelo moker). V nadaljevanju dijaki med zapisanimi možnostmi poiščejo ustrezna nadaljevanja frazemov, jih nato uporabijo v povedih in razložijo njihov pomen (npr. počutiti se - kot riba v vodi: $V$ novi slu气̌bi se počuti kot riba v vodi. V novi slu气̌bi se zelo dobro počuti.). Pri eni od nalog morajo dijaki $\mathrm{v}$ navedenih povedih najti frazeme in jih nadomestiti $\mathrm{s}$ slogovno nezaznamovanimi besednimi zvezami, nato pa pri naslednji nalogi ugotoviti, $\mathrm{v}$ katerih besedilih bi lahko uporabili frazeme, $\mathrm{v}$ katerih pa bi bilo smiselno uporabiti nezaznamovane zveze besed. Zanimiva je ena zadnjih nalog, kjer dijaki poiščejo čim več frazemov, v katerih se pojavi eno od poimenovanj živali: jagnje, kǎ́a, kokooš, konj, maček, medved, muba, pes, mǐ̌, čebela in bik. Pri zadnji nalogi se dijaki navezujejo na pouk književnosti, saj morajo izbrati enega od frazemov, povezanega z določeno živaljo, in ob njem napisati svojo basen; ob tem ponovijo značilnosti te literarne zvrsti.

Delovni zvezek Napragu besedila $2 \mathrm{v}$ nalogah od dijakov pričakuje, da med zapisanimi besednimi zvezami ločijo proste (npr. spomniti se počitnic) in stalne (npr. španska stena), med stalnimi pa v naslednji nalogi prepoznavajo frazeme (npr. imeti strupen jęik). Pri nekaj nalogah morajo zapisati manjkajoči del frazema (npr. kot pes) ali dokončati pregovor (npr. Mladost je norost, .). V nekaj krajših odlomkih poiščejo frazeme (npr. Ko so mi vzelli uro, sem takoj vedel, koliko je ura.) ali pa $\mathrm{v}$ besedilo vstavijo ustrezni frazem od treh ponujenih. Frazemom morajo pripisati razlage (npr. Že dolo je pri krubu. - Je zaposlen.) ali protipomenske (npr. biti figa možbiti mož beseda) oz. sopomenske frazeme (npr. biti brez srca - imeti kamen namesto srca), ki pa so pri nekaterih nalogah že podani in jih je treba s prvotno danimi frazemi le ustrezno povezati; težje je seveda, ko morajo dijaki pomen frazemov samostojno 
razložiti ali jim pripisati protipomenske oz. sopomenske frazeme. Pri zadnjih dveh nalogah dijaki razložijo pomene svetopisemskih frazemov (npr. umiti si roke) in tistih, ki izvirajo iz antičnega sveta (npr. abilova peta) (Križaj Ortar idr., 2017b: 20-25).

Samostojni delovni zvezek Barve jezika 2 (Slemenjak 2017b) uvaja utrjevanje snovi z izhodiščnim neumetnostnim besedilom, iz katerega morajo dijaki izpisati frazeme in jim (samostojno) pripisati pomen (npr. padel sem na finto). Za razliko od prejšnjih pa ta delovni zvezek ponuja nalogo, kjer je treba podčrtani del povedi nadomestiti s frazemom (npr. Rodil se je doma). Znova pa je treba dopolniti frazeme ali pregovore (npr. stati kot ). Nekaj nalog se nanaša na poznavanje teorije: $\mathrm{v}$ katerih besedilih se pogosto uporabljajo frazemi, kako učinkuje raba frazemov $\mathrm{v}$ besedilih in s katerim namenom jih tvorci besedil uporabljajo. Pri eni od nalog smo opazili tudi navezovanje na poznavanje slovenske književnosti: dijaki namreč morajo razložiti pomen zveze dni mojih lepši polovica ter navesti avtorja zapisanih besed. Podobno kot $\mathrm{v}$ pripadajočem učbeniku je treba razložiti pomene ilustriranih frazemov.

\section{Težavnejše oblike}

Žiga Rebernik in Eva Malovrh sta v šolskem letu 2015/16 v raziskovalni nalogi, predstavljeni v nadaljevanju, med dijaki izvedla anketo o poznavanju frazeologije in frazemov. Ugotovila sta, da dijaki zlasti slabo poznajo frazeme, ki izvirajo iz antičnega sveta ali iz Biblije, saj je pri njih treba poznati zgodovinsko ozadje oz. mitologijo ali svetopisemske zgodbe. Opazila sta tudi, da veliko informantov navaja zgodovinske osebe, ampak v neustreznih zvezah (npr. Helenina vojna, Abilova jeza, Evina skušnjava ...).

Pri delu v razredu tudi sama opažam dvoje: 1) da dijaki ne poznajo stalnih oblik frazemov, ampak zapišejo le približek izvornega frazema (npr. imeti kamnito srce, priden kot pes, imeti luknjo v glavi, zabit kot stena); 2) za dijake je najtežje razložiti pomen svetopisemskih frazemov (npr. v potu svojega obraz̧a, glas vpijočega v pušcavi, zlato tele, grešni kozel, umiti si roke, Oko za oko, zob za zob, Beseda je padla na kamen, Kdor je brez. greha, naj prvi vrře kamen vanjo.). Podobno velja za frazeme, ki izvirajo iz grškorimskega sveta (npr. sizifovo delo, tantalove muke, gordijski vozel, prokrustova postelja, abilova peta, biti med scilo in karibdo, prestopiti rubikon, kolumbovo jajce). 


\section{Frazemi v raziskovalnih nalogah}

\section{Zapis osebnih lastnih imen $v$ frazemih}

Žiga Rebernik in Eva Malovrh (2016) sta kot dijaka 3. letnika pripravila raziskovalno nalogo Poljubiti matildo ali Matildo: zakaj je zapis osebnih imen v frazemih abilova peta?, $\mathrm{v}$ kateri sta proučevala osebna lastna imena $\mathrm{v}$ frazemih. $\mathrm{V}$ teoretičnem delu naloge sta predstavila in primerjala različne znanstvene razlage osnovne frazeološke enote, se posvetila frazeologiji kot jezikoslovni vedi in polistala po Slovarju slovenskih frazemov. $\mathrm{V}$ nadaljevanju sta se osredotočila na predmet proučevanja $\mathrm{v}$ frazemih, tj. osebna lastna imena. Posebno pozornost sta namenila pravilom Slovenskega pravopisa (dalje $S P)$, ki določajo zapis imen z veliko oz. z malo začetnico, ter dosedanjim raziskavam tega problema. Ugotovila sta, da pravila glede rabe velike oz. male začetnice pri osebnih imenih v frazemih niso povsem jasna oz. dopuščajo več možnosti, jezikovni viri (SP, obe izdaji SSKJ, Slovar slovenskih frazemov idr.) pa zato niso enotni; posledično se tudi v rabi pojavljajo odstopanja od pravopisnih pravil.

V praktičnem delu naloge sta frazeme, zbrane iz Slovarja slovenskih frazemov, analizirala $z$ več vidikov, pri tem pa sta se osredotočila na izvor osebnih lastnih imen. Ugotovila sta, da večinoma izvirajo iz grščine, latinščine in hebrejščine. Izvor imen sta nato smiselno povezala z izvorom posameznih frazemov. Tako so vsa imena iz frazemov, ki izvirajo iz grško-rimskega sveta, starogrškega izvora. Osebna imena iz frazemov, ki izvirajo iz Biblije, so večinoma iz hebrejščine, $\mathrm{k}$ nam pa so prišla preko stare grščine in latinščine. Zaradi stoletja dolgega germanskega vpliva na našem etničnem ozemlju pa lahko osebna imena $v$ frazemih, ki izvirajo iz ljudske govorice ali miselnosti, povežemo s starovisokonemškimi besedami.

V nadaljevanju praktičnega dela sta po korpusu Gigafida preverila upoštevanje pravopisnih pravil oz. odstopanje od njih v vsakdanji jezikovni rabi. Ugotovila sta, da v vseh frazemih, pri katerih lastna imena ob označevanju vrste pojavov prehajajo $\mathrm{v}$ obča poimenovanja, prevladuje zapis teh imen $\mathrm{z}$ malo začetnico. Frazemi $\mathrm{s}$ svojilnimi pridevniki, ki so izpeljani iz lastnih imen in zaznamujejo duhovno last, se lahko po SP pišejo z veliko ali z malo začetnico, a ugotavljata, da je zapis z veliko začetnico pogostejši. Pridevniki na -ov/-ev, -in, kadar ne zaznamujejo svojine, ampak vrstnost rastlin, bolezni, delov telesa ali tehničnih izumov, naj bi se $\mathrm{v}$ frazemih po $S P$ pisali z malo začetnico; po pregledu različnih jezikovnih virov in korpusa opažata, da so nekateri frazemi s tovrstnimi poimenovanji zapisani na oba načina. 
Ker so pravopisna pravila glede zapisa osebnih imen $v$ frazemih $z$ malo oz. $z$ veliko začetnico tako nejasna, upoštevanje norme pa je posledično nedosledno, sta mlada raziskovalca predlagala, da bi težavo razrešili z delitvijo frazemov z osebnimi lastnimi imeni in njihovimi izpeljankami $\mathrm{v}$ dve skupini:

1. frazemi, ki vsebujejo primerjavo: nag kot Adam, iti kot Elija, biti kot mila Jera ... Imena $\mathrm{v}$ teh frazemih bi pisali z veliko začetnico, saj izražajo lastnost neke (četudi mitične) osebe (npr. iti kot Elija pomeni 'iti hitro' (kot Elija), nag kot Adam pomeni 'biti popolnoma gol' (kot Adam) itn.);

2. vsi drugi frazemi, denimo preseliti se $k$ abrahamu, $v$ adamovi obleki, krmariti med scilo in karibdo ... Osebna imena $\mathrm{v}$ tej skupini frazemov bi pisali $\mathrm{z}$ malo začetnico. Sem bi razvrstili pridevniške in samostalniške oblike imen. Prve so večinoma svojilne pridevniške (npr. abilova peta pomeni 'slabost, ranljivo mesto' in ne 'peta od Ahila'), pojavita pa se tudi imeni v lastnostni pridevniški obliki (tantalske muke, meturalemska starost). Kot samostalniške oblike imen pojmujemo vsa imena, ki imajo v frazemu vlogo samostalnika (npr. poljubiti matildo pomeni 'umreti' in ne 'poljubiti osebo z imenom Matilda').

\section{Barve $\mathbf{v}$ frazemih slovenskega jezika}

Nika Skušek (2018), dijakinja 4. letnika v šolskem letu 2017/18, je pripravila raziskovalno nalogo Petdeset odtenkov slovenskih frazemov: kako z zlato sredino presekati govorniške sivino, $\mathrm{v}$ kateri se je osredotočala na barve $\mathrm{v}$ frazemih. Tudi ona se je najprej posvetila teoretičnemu delu naloge, $\mathrm{v}$ katerem je predstavila frazeologijo in preučila definicije njene osnovne enote - frazema. Nato je opisala zgradbo in nastanek Slovarja slovenskih frazemov, ki je bil osrednji vir njene naloge. V nadaljevanju je razmišljala o pomenu barv za našo kulturo in življenje ter podrobneje predstavila barve, ki se pojavljajo v slovenskih frazemih.

V praktičnem delu je zbrala frazeme iz Slovarja slovenskih frazemov, ki so vsebovali barvo kot sestavino ali jo izražali v svojem pomenu. Najprej jih je razvrstila glede na kvalifikatorje in nato še po izvoru. Največ frazemov je bilo ekspresivnih, njihov izvor pa je bil zelo raznolik. Najmanj jih je izviralo iz druge književnosti (npr. $v$ beli svet) in iz Biblije ali drugih religioznih besedil (npr. ₹lato tele, čm kot hudič), Nika pa je glede na zbrano gradivo dodala kategorijo iz vidnih in/ali fizičnih lastnosti (npr. priti na zeleno vejo, rdečkot ogen $)$. Veliko frazemov je bilo zgodovinskega izvora (npr. rjave srajce, 
siva eminenca), nekateri pa so izhajali iz ljudske govorice ali miselnosti (npr. ₹lata duša, imeti bela jetra). Zbrane frazeme je nato po barvah razvrstila $\mathrm{v}$ preglednice in njihove pomene poskusila smiselno povezati s simboliko barve. Pri tem se je pomen mnogokrat prepletal tudi z izvorom frazema. Nika je ugotovila, da je med frazemi z modro barvo prisotna povezava z bogovi (npr. biti modre krvi), pri rumeni pa s postaranostjo (npr. rumen kakor vosek), boleznijo (npr. rumen kot limona) in sporazumevanjem (npr. rumeni tisk). Prav tako je bila starost poglavitna simbolika sive barve (npr. delati sive lase komu, siv kot ovca). Zelena se je zaradi mnogo asociacij navezovala predvsem na rastlinstvo (npr. imeti zelene prste), zlata pa na bogastvo (npr. zlati gradovi, odkriti ₹lato jamo); zelena je zaradi povezave z žolčem pridobila negativno simboliko z izražanjem jeze, zavisti (npr. zelen od ježe). Pri rdeči sta poudarjena pomena za ogenj in kri, ki se v večini frazemov le nekoliko preoblikujeta (npr. $r$ dec kotpuran, rdeč kot kuhan rak). Izrazi, ki vsebujejo belo in rožnato, so navadno pozitivni (npr. dober kakor beli krub; v primeru rožnate olepševalni, npr. v ro:̌natih barvah), medtem ko ima črna značilno negativno simboliko (npr. slikati koga v črnih barvah, črni oblaki se zbirajo nad kom/ rim).

\section{Sklep}

Frazeologija kot del jezikovnega sistema zavzema pomemben delež v jezikovni rabi. Pri proučevanju in obravnavi frazemov slovenskega jezika se kaže vpetost $\mathrm{v}$ skupni evropski prostor, zgodovino in krščansko tradicijo. Raziskovalne naloge dijakov pa nakazujejo nove možnosti raziskav, ki jih nikakor ni mogoče izčrpati, saj lahko frazeme proučujemo z več vidikov. Ob raziskovalnem delu se namreč odpirajo zmeraj nova vprašanja in zagate, kažejo se ideje in rešitve, o katerih je vredno razmišljati. Hkrati smo z raziskavami želeli poudariti, da s pravo mero rabe frazemov v vsakdanjem sporazumevanju ohranjamo slovensko jezikovno kulturo, hkrati pa poskrbimo tudi za zadostno jezikovno barvitost.

\section{Viri in literatura}

Nataša JAKOP, 2006: Pragmatična frazeologija. Ljubljana: ZRC SAZU.

Janez KEBER, 2011: Slovar slovenskih frazemov. Ljubljana: ZRC SAZU.

Martina KRIŽAJ ORTAR idr., 2017a: Na pragu besedila 2. Učbenik za slovenski jezik v 2. letniku gimnazij in srednjih strokovnih šol. Ljubljana: Rokus.

- -, 2017b: Na pragu besedila 2. Delovni zvezek za slovenski jezik v 2. letniku gimnazij in srednjih strokovnih šol. Ljubljana: Rokus.

Eva MALOVRH, Žiga REBERNIK, 2016: Poljubiti matildo ali Matildo: zakaj je rapis osebnih lastnih imen v frazemih Abilova peta? Raziskovalna naloga. Maribor: Prva gimnazija Maribor. 
Mojca POZNANOVIČ, 2008: Ǔ̌ni načrt. Slovenšcina: gimnazija: splošna, klasična, strokovna gimnarija. Ljubljana: Ministrstvo za šolstvo in šport.

Nika SKUŠEK, 2018: Petdeset odtenkov slovenskih frazemov: kako z qlato sredino presekati govornišo sivino. Raziskovalna naloga. Maribor: Prva gimnazija Maribor.

Tanja SLEMENJAK idr., 2017a: Barve jezika 2. Učbenik za slovenščino v 2. letniku gimnazij in srednjih strokovnih šol. Ljubljana: Rokus.

- -, 2017b: Barve jerikea 2. Samostojni delovni zvezek za slovenščino v 2. letniku gimnazij in srednjih strokovnih šol. Ljubljana: Rokus.

Jože TOPORIŠIČ, 1973/74: K izrazju in tipologiji slovenske frazeologije. Jerik in slovstvo, slovstvo 19/8, 273-279, 273-279.

Jerca VOGEL idr., 2016a: Slovenščna 2: ₹ besedo do besede. Učbenik za slovenščino - jezik v 2. letniku gimnazij in srednjih strokovnih šol. Ljubljana: Mladinska knjiga.

- -, 2016b: Slovenš̌ina 2: z besedo do besede. Zbirka nalog za slovenščino - jezik v 2. letniku gimnazij in srednjih strokovnih šol. Ljubljana: Mladinska knjiga. 


\title{
Meni gre že vse na jetra!
}

\author{
GORDANA RODINGER
}

Povzetek Frazemi kot stalne besedne zveze s prenesenim pomenom so del našega vsakdana. Uporabljamo jih, ne da bi se tega sploh zavedali. Pri tem pomen frazema praviloma ni zlahka predvidljiv iz besed, ki ga sestavljajo, ampak se ga moramo naučiti, da frazem razumemo in da ga lahko učinkovito uporabljamo. V zadnjem vzgojnoizobraževalnem obdobju osnovne šole se s stalnimi besednimi zvezami srečamo v 7. razredu. Nekaterim učencem razumevanje stalnih besednih zvez ne predstavlja težav, učenci z bralno-zapisovalnimi težavami pa imajo težave $z$ razumevanjem prebranega, krajših in daljših sestavkov in še posebej z razumevanjem prenesenih pomenov. Učitelji slovenščine se tako znajdemo pred izzivom, kako tem učencem ne le pomagati, ampak jim pridobivanje novega znanja narediti zanimivo. $\mathrm{V}$ članku je prikazana ena od teh možnosti.

Ključne besede: $\bullet$ stalne besedne zveze $\bullet$ frazemi $\bullet$ preneseni pomen - bralno-zapisovalne težave $\bullet$ pouk slovenščine $\bullet$

NASLOV AVtOrice: Gordana Rodinger, Osnovna šola Pesnica, Pesnica pri Mariboru, Slovenija, epošta: gordanarodinger@gmail.com. 


\section{Uvod}

Kot učiteljica se že od začetka svojega službovanja srečujem z učenci, ki imajo pri slovenščini učne težave, najpogosteje bralno-zapisovalne. Z leti prakse in dodatnimi izobraževanji sem pridobila znanja in kompetence, ki mi pri delu pomagajo, čeprav me vsak učenec s svojim načinom razmišljanja vedno znova postavi pred izziv, kako naprej. Ugotovila sem, da so ti učenci po eni strani zelo občutljiva skupina, ki potrebujejo veliko razumevanja in prilagajanja, po drugi strani pa nas s svojim razmišljanjem in z drugačnimi pogledi na določene stvari večkrat lahko izredno presenetijo - tudi pri obravnavi stalnih besednih zvez s prenesenim pomenom.

\section{Meni gre že vse na jetta!}

Veliko otrok prenesene pomene besed uporablja v vsakdanjem govoru, a se tega niti ne zaveda. Meni gre že vse na jetra, je denimo izjava, ki jo osnovnošolci največkrat uporabijo takrat, ko želijo odraslim ali sovrstnikom sporočiti, da je s šolo vse narobe. In pri tem uporabijo frazem.

$\mathrm{V}$ osnovni šoli ne uporabljamo izraza frazem, ampak se $\mathrm{v}$ tretjem vzgojnoizobraževalnem obdobju srečamo z izrazom stalna besedna zveza. E. Kržišnik (1994) je že v devetdesetih letih 20. stoletja menila, da je slednji izraz v osnovni šoli najprimernejši, čeprav je ob tem poudarila, da se omenjena opredelitev navezuje le na besedne zveze, ne pa tudi na stavčne tvorbe.

V Učnem načrtu za slovenščino (2011) se stalna besedna zvez̧a kot jezikovni izraz pojavi v 7. razredu. Od učencev se pričakuje, da so sposobni spredstavi/ti/ pomen danih besed in stalnih besednih zvez ter jih smiselno uporablja/ti/ v novih povedih«. Zelo pomembno je, da se učenci zavedajo, da pomen stalnih besednih zvez ne izhaja iz pomena posameznih besed, ampak se je potrebno pomena stalnih besednih zvez kot celote enostavno naučiti. Prav tako po mnenju E. Kržišnik (1994) ni naključno, da so stalne besedne zveze kot jezikoslovni izraz v osnovni šoli vključene v tretje vzgojno-izobraževalno obdobje, saj je njihovo razumevanje odvisno od kognitivnega razvoja otrok, kar pomeni, da morajo imeti učenci dovolj izkušenj in znanja, da razumejo njihov pomenski prenos. Pri tem je tudi opozorila, da je zelo pomembno, da učitelji pri izboru stalnih besednih zvez upoštevajo otrokovo poznavanje zunajjezikovne dejanskosti oz. da so uporabljene stalne besedne zveze, ki so otrokom blizu. 
V 7. razredu učenci spoznajo, da besede povezujemo v besedne zveze, ki so lahko proste ali stalne, pri čemer se $\mathrm{v}$ prostih besednih zvezah lahko spremeni beseda, pomen pa se ne spremeni (majhen vrabec - drobcen vrabec). Naučijo se, da med stalne besedne zveze prištevamo frazeme (npr. ̌iveti kot vrabec v prosu), v katerih besed ne moremo poljubno zamenjevati, in pregovore (npr. Bolje vrabec v roki kot golob na strehi). »Pregovori so stalne besedne zveze, ki so v obliki povedi in jih ne moremo spreminjati« (Kumer idr. 2017: 13).

Učenci v 7. razredu stalne besedne zveze razumejo, dojemajo in uporabljajo glede na svoje sposobnosti. Posebej občutljiva skupina so otroci s primanjkljaji na posameznih področjih učenja. Pri pouku slovenščine so zaradi specifičnega načina dela med najbolj izpostavljenimi prav učenci z bralno-zapisovalnimi težavami. Pri tem je treba poudariti, da imajo $z$ razumevanjem pomena in $z$ uporabo stalnih besednih zvez težavo vsi učenci s primanjkljaji na posameznih področjih učenja, večkrat tudi dvojno izjemni učenci. Učitelji se moramo zavedati, da lahko z ustreznimi pristopi in strategijami poučevanja preprečimo, da so učenci neuspešni, in jim na različne načine omogočimo, da lahko napredujejo (Kavkler, Magajna 2008).

Učenci z bralno-zapisovalnimi težavami se pri pouku srečujejo z mnogimi ovirami. Pri obravnavi stalnih besednih zvez se mora učitelj zavedati, da ti otroci berejo počasneje in da imajo, ker se toliko ukvarjajo s samim branjem, težave $\mathrm{z}$ razumevanjem prebranega. $\mathrm{V}$ besedah zamenjujejo črke, kar lahko pri stalnih besednih zvezah še dodatno ovira razumevanje, večkrat ne prepoznajo niti že znanih besed. Določeno besedo pogosto nadomestijo z drugo, podobno besedo in težje uporabljajo slovarje. Zaradi naštetega težko razumejo prenesene pomene besed in jih tudi ne usvojijo dovolj dobro (Kesič Dimic 2015). Ker pa je pomembno, da učence $v$ osnovni šoli naučimo razumeti in uporabljati tudi stalne besedne zveze, sta pri pouku nujni diferenciacija in individualizacija. Zelo uspešno je lahko tudi individualno delo z učencem $\mathrm{v}$ okviru dodatne strokovne pomoči, pri kateri lahko učitelj izbere aktivnosti, ki slonijo na specifičnem učnem stilu, ki je posameznemu učencu najbližji; učitelj lahko omogoči različne načine predstavitve vsebin, uporablja lahko aktivne oblike dela in sproti preverja znanje ter učencu nudi sprotno povratno informacijo o napredku (Peklaj 2008). 


\section{Ko imeli so krompir ne pomeni, da so poskrbeli za ozimnico}

V nadaljevanju predstavljam individualno delo z učencem 7. razreda, ki ima bralnozapisovalne težave. Cilj učne ure je, da učenec »razume in uporablja stalne besedne zveze«. V letni pripravi za 7. razred za stalne besedne zveze načrtujem dve šolski uri, in sicer je prva šolska ura namenjena besednim zvezam in stalnim besednim zvezam, pri čemer se mi zdi zelo pomembno, da preverim njihovo razumevanje stalnih besednih zvez in pregovorov. Na osnovi njihovega predznanja namreč diferenciram delo in pripravim različne delovne liste. Med drugim me zanima, ali učenci vedo, kaj pomenijo naslednje stalne besedne zveze (frazemi in en pregovor):

- iti na šivce,

- imeti krompir,

- brusiti jezike,

- kupiti mačka v žaklju,

- kar labko storiš danes, ne odlašaj na jutri.

Vsakič ugotovim, da je $\mathrm{v}$ 7. razredu velika razlika med učenci, ki veliko berejo in imajo bogat besedni zaklad, ter med učenci, ki nimajo bogatega besednega zaklada in ne razumejo prenesenih pomenov besed. To je tudi razlog, da učencem naloge diferenciram na treh učnih listih.

Na prvem učnem listu so osnovne stalne besedne zveze in pregovori; učenci se učijo njihovega pomena in rabe v novih povedih. Gradivo velikokrat opremim s slikovnim gradivom (na primer tresel se je kot šiba na vodi).

Učenci v drugi skupini stalne besedne zveze in pregovore ne le razlagajo, ampak jih tudi dopolnjujejo (od ji je počilo srce).

Tretjo skupino največkrat sestavljajo učenci, ki so za slovenščino nadarjeni, veliko berejo in imajo bogat besedni zaklad. Trenutno imam v 7. razredu tudi učence, ki so zelo dobri na področju angleščine in slovenščine. Dobili so dve možnosti. Prva je bila ta, da so na osnovi danih stalnih besednih zvez in pregovorov sestavili zgodbo o sedmošolcu, ki ne mara šole in ne športa, rad pa ima stripe. Druga naloga je bila namenjena učencema, ki sta zelo dobra pri angleščini in sta iskala in primerjala stalne besedne zveze $\mathrm{v}$ slovenščini in angleščini. 
Učenci so na notranjo diferenciacijo navajeni, prav tako vedo, da se skupine glede na temo in zahtevnost spreminjajo.

V 7. razredu pa imam tudi učenca, ki ima dislektične težave, njegova grafomotorika je okorna in počasna, ob tem ima velike težave s koncentracijo, je pa zelo delaven in se pri pouku zelo trudi. Individualno uro sva začela s pogovorom o tem, da sem imela pa res krompir, da sem avgusta pravočasno obiskala żdravnika. Ugotovila sem, da me ni razumel in ko sem vprašala, kaj je narobe, me je vprašal, kaj ima krompir z mojo boleznijo. Skozi pogovor sem mu razložila, da včasih za vsakdanje stvari uporabimo nadomestne besedne zveze, s katerimi enako povemo na drugačen način. Dala sem mu bolj vsakdanji primer: pevec je postal slaven čez noč. Primer je poznal in vprašala sem ga, če morda tudi sam kdaj uporabi kaj podobnega. Omenil je, da pogosto reče, da mu gre kaj na jetra ali da ima smolo. Skupaj sva razlagala stalne besedne zveze, ki sem jih imela zapisane (priden kot mravlja, ugrizniti v kislo jabolko, dreti se kot sraka ...). Nato sem mu pripravila nalogo, pri kateri je slikovno gradivo (sličice) povezal s stalnimi besednimi zvezami: padel je z lune, luna ga nosi, luna ga trka, Peter je za luno. O vseh pomenih sva se tudi pogovorila in podal je primere, $v$ katerih jih lahko uporabi. Omenila sem že, da ima učenec težave tudi s koncentracijo, zato je pomembno, da vmes vstaneva ali zamenjava način reševanja nalog. $V$ tem primeru sem mu odprla spletno stran www.učiteljska.net, saj zelo rad rešuje naloge s pomočjo računalnika. Spletne naloge so preproste in ponujajo rešitve, kar mu je blizu. Primer naloge, pri kateri med ponujenimi možnostmi izbere ustrezen odgovor: Besedo je snedla: a) besedo je dobro prežvečila in pojedla, b) svoje obljube ni izpolnila, c) na kruh je namazala besedo in pojedla. $\mathrm{Ob}$ odgovorih sva se zabavala in ugotavljala, da je zelo pomembno, da stalnih besednih zvez ne povezujemo $z$ dobesednimi pomeni besed, ampak pomislimo, kaj vse bi te besede, sestavljene v neko zvezo, pomenile. Ura je bila uspešno izvedena in prepričana sem, da učenec razume in zna uporabljati nekatere obravnavane stalne besedne zveze.

\section{In tako se mu je odvalil kamen od stca}

Vsi učenci so radi uspešni. Vsi učenci radi slišijo, da so nekaj naredili zelo dobro in da so napredovali. Težko je biti nenehno neuspešen in učitelji se tega moramo zavedati. Prav zato je pomembno, da delo, kadar je to mogoče, diferenciramo in individualiziramo ter učencem omogočimo, da pridejo do cilja na drugačen način. Pomembno je, da učitelj svoje učence pozna, da ve, kaj lahko od njih pričakuje. Dejstvo je, da so nekatere vsebine bližje dekletom, druge dečkom, pri tretjih 
zablestijo nadarjeni učenci itd. Razumevanje in raba stalnih besednih zvez za sedmošolce ni tako preprosta, kot je morda videti na prvi pogled. Še največ težav imajo s tem učenci, ki nimajo bogatega besednega zaklada, in učenci, ki imajo primanjkljaje na določenih področjih učenja, saj težje razumejo prenesene pomene besed in morajo nekatere stalne besedne zveze ponotranjiti, da jih lahko razumejo in kasneje tudi uporabljajo. Vloga učitelja je pri tem velika. Pomembno je, da se tega dejstva zaveda in da učencem pri obravnavi tako umetnostnih kot neumetnostnih besedil pomaga razumeti stalne besedne zveze in pregovore. Eden od učinkovitih načinov usvajanja leksike, ki ga uporabljamo učiteljice slovenščine na naši šoli, je tudi »slovarček«, kamor učenci vpisujejo nove besede, definicije, pojme, ki se jih naučijo pri slovenščini. Saj veste, ko učenec ugotovi, da ima prav, se mu odvali kamen od srca

\section{Viri in literatura}

Erika KRŽIŠNIK, 1994: Frazeologija kot izražanje v „podobah“. Pouk slovenščne malo drugače. Ur. A. Kozinc. Trzin: Different, d. o. o. 91-103.

Marija KAVKLER, Lidija MAGAJNA, 2008: Učne težave kot posebne vzgojno-izobraževalne potrebe - opredelitev, razsežnosti in podskupine učnih težav. Ǔ́ne težave v osnovni šoli. Ur. A. Nagode. Ljubljana: Zavod RS za šolstvo. 23-31.

Katarina KESIČ DIMIC, 2015: Vsi učenci so labko uspešni. Napotki za delo z učenci s posebnimi potrebami. Ljubljana: Rokus Klett.

Vesna KUMER idr., 2017: Slovenšina v oblaku. Knjižni in neknjižni jezik. Samostojni delovni zuezele za slovenšcino v 7. razredu osnovne šole. Ljubljana: Rokus Klett, d. o. o.

Cirila PEKLAJ, 2008: Učenci z učnimi težavami v razredu - priporočila za učitelje. Učne težaveve v osnovni šoli. Ur. A. Nagode. Ljubljana: Zavod RS za šolstvo. 71-77.

Ǔ̌ni načrt. Slovenšina. 2011. Dostopno 12. 3. 2019 na http://www.mizs.gov.si/fileadmin/mizs.gov.si/pageuploads/podrocje/os/prenovljeni_UN/ UN_slovenscina_OS.pdf. 


\title{
Frazeologija v Prešernovem Povodnem možu
}

\begin{abstract}
NIVES VIDIC
Povzetek Obravnavani prispevek prinaša spoznanja o prepoznavanju stalnih besednih zvez oziroma frazemov v Prešernovem Povodnem mo:̌ Poznavanje nekaterih Prešernovih pesmi, med drugim tudi te balade, spada v osnovnošolski nabor kanonskih besedil. Nekatere Prešernove pesmi s pomočjo slikanic obravnavajo že v predšolskem obdobju in $\mathrm{v}$ prvih dveh vzgojno-izobraževalnih obdobjih osnovne šole. Ob branju balade me je zanimalo, v kolikšni meri osmošolci prepoznavajo, razumejo in znajo uporabiti frazeme, ki so jih našli v pesmi.
\end{abstract}

Ključne besede: • pouk slovenščine $\bullet$ stalna besedna zveza $\bullet$ frazem • France Prešeren $\bullet$ balada $\bullet$

NASlov AvTORice: Nivec Vidic, Osnovna šola Draga Bajca Vipava, Vipava, Slovenija, e-pošta: nives.vidic@os-vipava.si. 


\section{Uvod}

Frazeologija je del našega jezikovnega izražanja. Osnovnošolski pouk zajema tako pojasnjevanje frazemov v sklopu obravnavanih umetnostnih besedil kot teoretično seznanjanje učencev s pojmi, kot so stalna besedna zveza, frazem/reklo in pregovor. Tema tega članka so frazemi v Prešernovi baladi Povodni moそ̌.

Marija Stanonik (2012: 384) v monografiji Folkloristični portreti iz treh stoletij govori o Karlu Štreklju kot o preučevalcu folkloristike in pri tem ugotavlja, da je Štrekelj Prešernovo poezijo začel analizirati s stališča frazemov. Ugotavlja, da je Prešeren iz žive ljudske govorice frazeme prenašal v pesniški jezik, in navaja tudi posamezne primere, kot so ugnati v kozji rog, vezati otrobe, kazati osle, brusiti si jezilee ipd.

Osmošolci, ki v sklopu umetnostnih besedil spoznavajo Prešernovega Povodnega moža kot kanonsko besedilo (prim. Mileva Blažić 2008), so že seznanjeni s pojmom stalna besedna zveza. Definicija, ki jo poznajo, se glasi: Stalne besedne zveze so tiste, med katere ni mogoče vriniti še katere druge, dodatne besede. Prav tako že poznajo stalne besedne zveze s prenesenim pomenom oziroma izraz frazem. Za stalne besedne zveze je značilno, da so večbesedne, ustaljene in semantično celovite, za frazeme in pregovore pa je poleg naštetega značilno še, da so slogovno zaznamovani, čustveno/ekspresivno obarvani in da imajo konotativni pomen.

Poznavanje frazemov je sestavni del besednega zaklada, prav bogatenje besedišča pa je del funkcionalnih in izobraževalnih ciljev pri pouku slovenščine v OŠ.

\section{Iskanje stalnih besednih zvez oz. frazemov v baladi Povodni mož}

Obravnava pesmi Povodni mož (prim. Kodre 2018), ki običajno traja od 3 do 4 ure, je osredotočena na spoznavanje stalne pesniške oblike (balada), pesniških izraznih sredstev (okrasni pridevki, poosebitve, primere, stopnjevanje, glasovno slikanje, rima, ritem ...), posveča se tudi okoliščinam nastanka pesmi, etičnim lastnostim glavne osebe, interpretativnemu branju, pisnemu poustvarjanju ipd. Pri tem je navadno premalo časa, da bi se podrobneje posvečali frazeologiji, zato je smiselno, da je obravnava frazemov v Povodnem mo:̌ vezana bodisi na motivacijsko uro bodisi na sprotno pojasnjevanje ob branju/spoznavanju besedila. Lahko pa frazeme vključimo tudi v domačo nalogo. 
Po uvodni motivaciji (vezani na pravljična in bajeslovna bitja ali odlomek iz Valvasorjeve Slave vojvodine Kranjske ali ljudske pesmi Povodni mo ̋ै sledi branje in literarnoestetsko doživetje.

Ob slikanici Povodni mož (ilustracije Jelke Reichman) povzamemo dogajanje.

Od kitice do kitice pesem preberemo še enkrat. Učencem pripravim razrezanko s posameznimi naključno izbranimi kiticami. Delajo v dvojicah ali manjših skupinah z učiteljevo pomočjo.

\section{Primer}

Od nékedaj lepé so Ljubljanke slovele, al lepsis od Urške bilo ni nobene, nobene orem bilo bolj ză̌elene ob času nje cvetja dekleta ne řenene. Ko nárbolj iz zvezd je danica svetla, narlepšs i iz deklic je Urška bila.

1. Lahko razbereš kraj dogajanja?

2. S katerim pridevnikom pesnik označi Urško in Ljubljančanke?

3. S čim pesnik primerja Urško?

4. Kako rečemo temu pesniškemu izraznemu sredstvu?

5. Katero metaforo je pesnik uporabil?

Poleg običajnih nalog pa so morali učenci preveriti tudi, katere stalne besedne zveze oziroma frazeme najdemo v besedilu. Dobili so naslednja vprašanja:

1. V besedilu podčrtajte stalne besedne zveze in pojasnite svojo odločitev.

2. Podčrtane stalne besedne zveze napišite $\mathrm{v}$ osnovni obliki.

3. Skušajte ugotoviti, ali gre za frazeološko ali nefrazeološko stalno besedno zvezo, in svojo odločitev utemeljite.

4. Frazeološke enote zamenjajte $z$ nefrazeološkimi ustrezniki. 


\section{1. kitica}

Od nékedaj lepé so Ljubljanke slovele, al lepsi od Urskee bilo ni nobene, nobene orem bilo bolj zažlene ob času nje cuetja dekleta ne žene. Ko nárbolj iz zvezd je danica svetla, narlepši iz deklic je Urškea bila.

V 1. kitici so učenci podčrtali zvezo ob času nje cvetja in jo pojasnili s primerom: ostani $v$ cvetju. Po njihovem mnenju to pomeni, da ostaneš mlad, zdrav, živahen, lep ... V Slovarju slovenskih frazemov (Keber 2015) sicer najdemo naslednje enote s sestavino cvétje: bíti v cvétju ('biti uspešen, ugodno se počutiti'), bódi v cvétju, bodíte $v$ cvétju. Učenci so torej podčrtali ekspresivno zvezo, ki jih je spominjala na frazem, ki so ga sicer poznali.

\section{2. kitica}

\section{Mnogtére device, mnogtére ženice oko je na skrivnem solzé preliválo, ker Urški srce se je ljubega vdalo; al ljubih bilo je nji vedno premalo. Kar slišala moških okrog je slovét, skušála jîh v mreže razpete je ujet.}

Iz 2. kitice so izpisali skušala moške v mrę̌re razpete je ujet (za Urški srce se je ljubega vdalo pa niso bili prepričani, ali ustreza ali ne). Prvi primer so pojasnjevali s pajkom, ki v mrežo ujame muho, ali ribičem, ki z mrežo lovi ribe.

V Slovarju slovenskih frazemov (Keber 2015) najdemo naslednje frazeme s sestavino mréža: kot pájek plêsti mréžo, kot pájek tkáti mréžo, plêsti mréžo ('pripravljati ugodne okoliščine, razmere za dosego določenega cilja'); enota vjeti koga v mrežo torej ni navedena. 


\section{3. kitica}

Je znala obljúbit, je znalá odreči, in biti priljudna, in biti prevzetna, mladenče unémat, bit staršim prijetna; modrij in zuijač je bila vseh umetna; možake je dolgo vodila za nos, ga stakne nazadnje, ki bil ji je kos.

$\mathrm{V}$ tej kitici so bili prepričani, da se frazem skriva v verzih možake je dolgo vodila za nos in ga stakne nazadnje, ki bil ji je kos. Prvi primer so pojasnili z razlago imeti za norca, drugega pa s konkretnim primerom: Bilsem kos nalogi. V tej kitici so bili torej dejansko pozorni na dva frazema: voditi koga za nos in biti kos komu. V Slovarju slovenskih frazemov (Keber 2015) pri sestavini nos najdemo posamostaljeno obliko vlécenje za nós in vléci kóga za nós $\mathrm{v}$ pomenu 'varati koga' (uporabljen je torej glagol vlečr); najdemo pa tudi frazem bíti kós kómu/č́mu v pomenu, da je kdo telesno ali duševno dovolj močen, sposoben za izvršitev določenega dela.

V 4. in 5. kitici učenci niso našli frazemov niti stalnih besednih zvez (npr. Stari trg).

\section{6. kitica}

Al, ker se ozira, plesavca si zbira, zagleda pri mizi rumeni junaka; enacga pod soncam mu ni korenjaka, želi si plesáti z njïm deklica vsaka omrežit ga Uršika lepa želi, zaljubljeno v njega obrača oči.

V tej kitici so mislili, da je frazem zveza želi ga omrě̌iti (razumeli so jo v smislu, da ga želi ujeti, osvojiti: ga osvaja). Učenci so menili tudi, da je frazem obračati oči (povezovali so ga s pomenom, da komu kaj ni všeč).

V 7., 8., 9. in 10. kitici učenci niso našli frazemov. 


\section{1. kitica}

So brě pridrvili se črni oblaki, zasliši na nebu se strašno gromenje, zasliši vetrov se sovražno vršenje, zasliši potokov derečih šmenje, pričjóčm po koncu so vstali lasje oh, Ursikea zala, zdaj tebi gorje!

V tej kitici so kot frazem opredelili zvezo so vstali lasje. Učenci so se zavedali, da so jim lasje vstali od groze, sami pa to zvezo poznajo, ko komu vstanejo lasje od jeze. Z grozo/strahom povezujejo tudi, da jim vstanejo dlake, da se naježijo. V Slovarju slovenskih frazemov (Keber 2015) sta navedena frazema lasje so se naježili komu, lasje so šli pokonci komu - v obeh primerih gre za občutenje groze, odpora.

V zadnjih treh kiticah (12., 13. in 14.) učenci niso navajali frazemov.

\section{Sklep}

Skupina štirinajstih osmošolcev se je pričakovano osredotočala na primarna vprašanja v zvezi z obravnavano balado Povodni moæ̌. Iskanje stalnih besednih zvez oz. prepoznavanje frazemov je bilo zgolj vzporedno dejanje. Izkazalo se je, da so zanje ta vprašanja težka, a so z učiteljevo pomočjo, sugestijo (preberite še enkrat, preverite ...) v vseh skupinah frazeme vendarle prepoznali. $\mathrm{Na}$ stalne besedne zveze brez prenesenega pomena niso bili pozorni. Težave so imeli tudi pri pojasnjevanju frazemov ( $v$ enem primeru so frazem pojasnili z drugim, sinonimnim frazemom: voditi za nos - imeti za norca). Pojma osnovna oblika frazema še niso poznali, so se pa z njim seznanili pri pouku oziroma doma, ko so brskali po spletnem frazeološkem slovarju. Načeloma bi učenci znali uporabiti frazeme v govoru, vendar jih - po njihovem mnenju - v vsakdanjem govoru ne uporabljajo. Kljub temu smo poiskali nekaj frazemov, ki jih uporabljajo, npr. iti na živce, iti na jetra, imeti za norca, neumen/ zabit kot tema/ noć, imeti koga na piki, ne imeti vseh kolesc v glavi. Frazemi, ki jih uporabljajo, so vezani predvsem na njihovo socialno okolje. Zanimiv se jim je zdel tudi izvor frazemov, ko smo se pogovarjali, zakaj pride kedo na boben, zakaj se obesi kaj na klin ipd. 


\section{Literatura}

Milena MILEVA BLAŽIĆ, 2008: Slovenska mladinska književnost med kulturami - študij primera: Prešeren - mladinski pesnik. Zbornike Slavističnega društva Slovenije 19. Ur. Miran Košuta. Ljubljana: Slavistično društvo Slovenije. 69-74.

Janez KEBER, 2015: Slovar slovenskih frazemov. Spletna izdaja na spletišču Fran. Dostop 2. 4.2019 na: https://fran.si/192/janez-keber-frazeoloski-slovar-slovenskega-jezika.

Petra KODRE, 2018: Od glasov do knjižnih svetov 8. Ljubljana: Založba Rokus Klett, d. o. o.

Marija STANONIK, 2012: Folkloristični portreti iz treh stoletij: od baroka do moderne. Ljubljana: Založba ZRC.

Naucite se tehnike paralelnega razmišljanja, 2011. Dostop 10. 2. 2019 na: http://www.mizs.gov.si/fileadmin/mizs.gov.si/pageuploads/podrocje/odrasli/Gradiva_ESS /CVZU/LU_Maribor/CVZU_38AZMB_Naucite.pdf 


\title{
Kam bomo pa danes odpotovali?
}

\author{
GORDANA RODINGER
}

\begin{abstract}
Povzetek Projektno učno delo je pri pouku slovenščine v osnovni šoli zelo pomembno, saj učencem omogoča večjo aktivnost in pridobivanje znanja na drugačen, samostojen, trajnostni način. V 7. razredu učenci spoznavajo opis države. Projektno delo pri omenjeni temi omogoča medpredmetno povezovanje z geografijo, prav tako pa učitelj lahko delo ne le diferencira, ampak predvsem individualizira in nadarjenim učencem omogoči, da pripravijo ustvarjalne, drugačne opise držav. Tudi na naši šoli z učiteljico geografije že več let pripravljava projektno delo, ki je medpredmetno povezano, pri čemer učenci opis države najprej spoznajo pri slovenščini, pri geografiji pa omenjeno znanje nadgradijo. Navodila pripraviva skupna, kar omogoča, da lahko učenec podatke uporabi pri obeh predmetih, končni izdelek pa predstavi na obeh področjih.
\end{abstract}

Ključne besede: • projektno delo • medpredmetno povezovanje • individualizacija $\bullet$ diferenciacija $\bullet$ nadarjeni učenci $\bullet$

NASLOV AVtORICE: Gordana Rodinger, Osnovna šola Pesnica, Pesnica pri Mariboru, Slovenija, epošta: gordanarodinger@gmail.com. 


\section{Uvod}

Ko stopiš $\mathrm{v}$ razred, se zaveš, da imajo učenci različne interese in različne sposobnosti. Želiš si, da bi pri pouku slovenščine vsi veliko pridobili, zato pomisliš: Kaj jim lahko ponudim? Ena izmed možnosti se skriva v sodelovanju s kom iz kolektiva, ki te razume. $Z$ učiteljico geografije in zgodovine sva že pred leti primerjali učne načrte in preverili, kaj lahko »poveževa" pri najinih urah. Ugotovili sva, da lahko učenci $v$ 7. razredu opisujejo državo, $v 8$. razredu naravni pojav in kmečke upore, $v$ 9. razredu pa obdobje druge svetovne vojne. Učenci takšno delo sprejmejo dobro in veseli so, da lahko za »eno narejeno stvar« prejmejo dve oceni.

\section{Načrtovanje pouka}

Pouk slovenščine $\mathrm{v}$ osnovni šoli omogoča tako horizontalno kot vertikalno medpredmetno povezovanje. To je za učence pomembno, saj jim omogoča, da dele neke snovi povežejo v celoto. Medpredmetno načrtovanje od učitelja zahteva nekaj več priprave; ker je treba delati $\mathrm{v}$ timu, pomeni, da od učitelja zahteva tudi prilagajanje. Učni načrti predpostavljajo, da se učitelji pri svojem delu medpredmetno povezujejo, torej da svoje cilje prepletajo in usklajujejo s cilji drugih predmetnih področij (Rutar Ilc, Pavlič Škerjanc 2010).

Medpredmetno povezovanje lahko v razredu izpeljemo na različne načine, odvisno od našega končnega cilja. Opis države v 7. razredu načrtujeva kot projektno učno delo, kar pomeni, da je delo treba načrtovati tako, da so zajeti cilji posameznega predmeta, pri čemer je tema zaokrožena in zajema več ur dela. Učenci morajo biti s temo pri obeh predmetih že delno seznanjeni, tako da projektno delo pomeni nadgradnjo njihovega védenja (Novak 2009).

Projektno učno delo naj bi omogočalo, da se upoštevajo interesi otrok, saj je zelo pomembno, da se v vzgojno-izobraževalnem procesu spodbujajo interesi in močna področja otrok; prav to jih namreč spodbuja, da so pri tovrstnem delu bolj aktivni, kot bi bili sicer. Projektno delo omogoča tudi vključevanje različnih aktivnosti (Novak 2009). 
Velik izziv pri delu v razredu učitelju predstavljajo nadarjeni učenci. S predstavljenim načinom dela se še posebej izkažejo ustvarjalni učenci, za katere je značilno, da imajo veliko idej in so fleksibilni. Moramo se namreč zavedati, da se nadarjeni učenci pri pouku večkrat dolgočasijo, zato je zelo pomembno, da so prepoznani. Jezikovno nadarjen otrok je občutljiv za podrobnosti v jeziku, bogato izraža svoje misli in je zelo dober pri pisanju pisnih izdelkov ter pripravi in izvedbi govornih nastopov (Kerndl 2016).

Kadar pripravljamo projektno delo in imamo v skupini nadarjene učence, moramo upoštevati, da ti učenci hitro dojemajo in da lahko takoj uporabijo podatke ter jih povežejo z že znanim. Največkrat lahko pri usvajanju novih snovi kakšen korak tudi izpustijo. Njihovi interesi so raznovrstni in večkrat so nenavadno radovedni, ob tem pa imajo bogat besedni zaklad, zelo fleksibilno razmišljajo, kar jim omogoča ustvarjanje izvirnih zamisli in rešitev. Pri tem vsi nadarjeni učenci niso tudi ustvarjalni, vendar številnim znanje, ki ga imajo, omogoča, da so v mišljenju boljši od svojih sošolcev (Heacox 2015).

\section{Kam bomo pa danes odpotovali?}

V 7. razredu je primer projektnega učnega dela, ki je hkrati medpredmetna povezava z geografijo, opis države. Z učiteljico geografije skupaj določiva cilje in pripraviva okvir, s pomočjo katerega lahko učenci pripravijo opis države in ga uporabijo pri obeh predmetih. Zaradi specifike dela učiteljica poda nabor držav, ki sovpadajo z njenim učnim načrtom. Pri slovenščini je v ospredju, da učenec pozna, razume, opiše in pravilno uporablja jezikoslovne izraze, določene z učnim načrtom; tvori smiselna, razumljiva, ustrezna, učinkovita in pravilna besedila; med govornim nastopanjem in med pogovarjanjem z učiteljem govori knjižno; pri tvorjenju besedil učinkovito, smiselno in ustrezno uporablja nebesedne spremljevalce govorjenja, pisanja (Učni načrt za slovenščino 2011).

Opis države kot neumetnostno besedilo učenci spoznajo že prej in vedo, da mora vsebovati uradno ime države, lego, glavno mesto, simbole, naravne in kulturne znamenitosti ipd. Učenci se lahko v skupine razvrstijo po interesih, in sicer glede na državo, ki jo želijo predstaviti. Dam jim možnost, da predstavitev pripravijo tudi sami. V uri, ko naredijo načrt, jim tudi povem, da bodo opis te države čez mesec dni uporabili tudi pri geografiji, vendar na drugačen način. 
Učenci pripravijo načrt govornega nastopa; vpišejo državo, ki jo želijo predstaviti, podatke, ki jih o državi že vedo, in podatke, ki jih želijo izvedeti, način predstavitve ter zadolžitve posameznega člana. Skupaj pripravimo kriterije uspešnosti, ki jih nato pretvorim $\mathrm{v}$ kriterije ocenjevanja (pri tem seveda kaj dodam in spremenim) ter $\mathrm{z}$ njimi seznanim učence. Za pripravo opisa države imajo na razpolago 4 ure. Od njihove ideje je odvisno, kako bodo državo predstavili. Učenci se še vedno najraje poslužujejo PPT-predstavitev ali izdelave plakata. Bolj ustvarjalni izdelajo turistične zloženke, makete, plakate v obliki državnih simbolov ...

V 7. razredu, $v$ katerem poučujem, je $v$ skupini pet nadarjenih učencev, štiri dekleta in en deček. Deček se je odločil, da bo sodeloval v skupini z drugimi dečki, v kateri je prevzel vlogo vodje in jih usmerjal. Opis države, ki so ga pripravili, je bil dobro napisan in je vseboval vse, kar je, glede na kriterije uspešnosti, v opis države potrebno vnesti. Tri dekleta so se odločila, da bodo Francijo predstavile s pomočjo 3D-plakata. Predstavitev je bila zanimiva, plakat pa je njihovo delo vsekakor nadgradil. Tudi drugi učenci so se strinjali, da jim »je zelo uspelo«. Zadnja deklica, ki je nadarjena tudi na voditeljskem področju, se je odločila, da bo opis države pripravila samostojno. Odločila se je, da bo predstavila Nemčijo. Pri delu sem jo pustila, da je sama odločala o vsem, čeprav je večkrat (še posebej pri sestavljanju besedila) preverila, če je na pravi poti. In res je bila. $\mathrm{Na}$ dan predstavitve je $\mathrm{v}$ šolo prinesla nekaj rekvizitov: klobuk, očala in lutko. Nemčijo je predstavila kot turistična vodička na avtobusu, ki svoje turiste popelje skozi raznoliko pokrajino. Pri tem je odigrala vlogo šoferja (lutka), turistične vodičke (očala) in nadležnega turista (kapa). Pripravila je opis države in ga zanimivo nadgradila z izvirno izvedbo.

\section{In ko prispemo na cilj}

Vesela sem, ko učencem omogočim, da aktivno sooblikujejo nastanek neke učne vsebine. Pri tem se zavedam, da to vedno ni mogoče in da pouk ne more biti le »zabava«. Včasih je učenje tudi trdo delo. Projektno delo je zagotovo oblika, ki učencem omogoča, da so aktivni in da izkoristijo svoja močna področja, učitelju pa, da delo individualizira in diferencira. Res je, da sama priprava zaradi iskanja gradiva in idej traja nekoliko dlje, a je ves trud poplačan s končnimi izdelki. 
Nadarjenosti učencev se učitelji ne smemo bati, biti nam mora $\mathrm{v}$ izziv, četudi zastavljajo vprašanja, na katera vedno ne najdemo odgovora. Zavedati se moramo, da nadarjenih učencev ne zanimajo vse vsebine, ki jim jih ponudimo pri pouku (četudi mislimo, da smo se zelo potrudili, so lahko za njih še vedno nezanimive). Projektno delo pa je vsekakor eden izmed načinov, pri katerem lahko izkažejo svoje interese in nadgradijo svoje znanje, dovoliti pa jim moramo, da se lahko izrazijo tako, kot si sami želijo. Če jih ustrezno usmerimo, bodo svoje znanje na različne načine znali povezati tudi na več predmetnih področjih.

\section{Viri in literatura}

Diane HEACOX, 2015: Diferenciacija za uspeh vseh. Ljubljana: Rokus Klett.

Milena KERNDL, 2016: Sodoben pouk (književnosti) in razlike med njimi. Murska Sobota: Založba BoMa. Helena NOVAK, 2009: Projektno delo kot učni model. Projektno delo kot ućni model v vrtcih in osnounih šlah. Radovljica: Didakta. 11-63.

Zora RUTAR ILC, Katja PAVLIČ ŠKERJANC, 2010: Medpredmetne in kurikularne povezave: priročnik za učitelje. Ljubljana: Zavod za šolstvo.

Ǔ́ni načrt. Slovenščna. 2011. Dostopno 12. 3. 2019 na

http://www.mizs.gov.si/fileadmin/mizs.gov.si/pageuploads/podrocje/os/prenovljeni_UN/ UN_slovenscina_OS.pdf 


\title{
Obravnava neumetnostnega besedila - neuradno pismo
}

\author{
MOJCA JERALA - BEDENK
}

\begin{abstract}
Povzetek Prispevek je vezan na konkretno obravnavo neumetnostnega besedila v 7. razredu, in sicer na pisanje pisma. Delo je potekalo $\mathrm{v}$ učnih skupinah in po smernicah postopnosti tvorjenja besedila. Tako smo uro za uvodno motivacijo začeli s pogovorom in na pol strganimi pismi, nadaljevali $z$ dopolnjevanjem manjkajočega besedila, nato pa so učenci že samostojno tvorili tudi celotno besedilo. Za zaključek smo ponovili dele pisma in zapis podatkov na kuverti. Uvodna motivacija je bila nadvse ustrezna, saj so učenci pisanje pisem vzeli kot igro iskanja skritega zaklada.
\end{abstract}

Ključne besede: $\bullet$ pismo $\bullet$ dopolnjevanje besedila $\bullet$ tvorjenje besedila

- skupinsko delo $\bullet$ 7. razred •

NASLOV AVTORICE: Mojca Jerala - Bedenk, Osnovna šola Vižmarje Brod, Ljubljana, Slovenija, e-pošta: jerala.bedenk.mojca@osbrod.si. 


\section{Uvod}

Danes so dobra stara pisma že skoraj pozabljena. Učenci redko še pridejo v stik s klasičnim pismom, zaradi česar imajo težave že s pisanjem naslova na kuverto, prav tako pa tudi s pisanjem pisma z vsemi njegovimi elementi. Pa vendar bi ga morali znati napisati, saj bodo kot bodoči odrasli uporabniki pisnega komuniciranja velikokrat postavljeni v situacijo, ko bodo morali napisati pismo, čeprav njegovo posodobljeno, elektronsko različico. Tako sem se lotila obravnave pisma na nekoliko drugačen način.

\section{Potek učne ure}

Že pred začetkom ure sem mize razporedila za skupinsko delo in nanje razvrstila nekaj pisem in razglednic. Učenci so se nato sami razdelili v skupine po tri ali štiri. Takoj so začeli obračati pisma, jih odpirati in vprašujoče gledati vame, saj si pisma niso upali potegniti iz kuverte. Stekel je pogovor o pisanju pisem. Povprašala sem jih, če morda kaj vedo o pismih, npr. kdo so golobi pismonoše, kako hitro so včasih dobivali pisma, kaj mora pismo imeti, da ga sploh lahko pošljemo. Ugotovila sem, da učenci skoraj ne poznajo izraza znamka, da vedo, da mora biti na kuverti napisan točen naslov, niso pa vedeli, kje se napiše, in ugibali so, kaj vse bi lahko v pismu pisalo.

Nato sem jih spodbudila, da si pisma ogledajo. V kuverte sem namreč pripravila pismo, ki je izgledalo takole: 


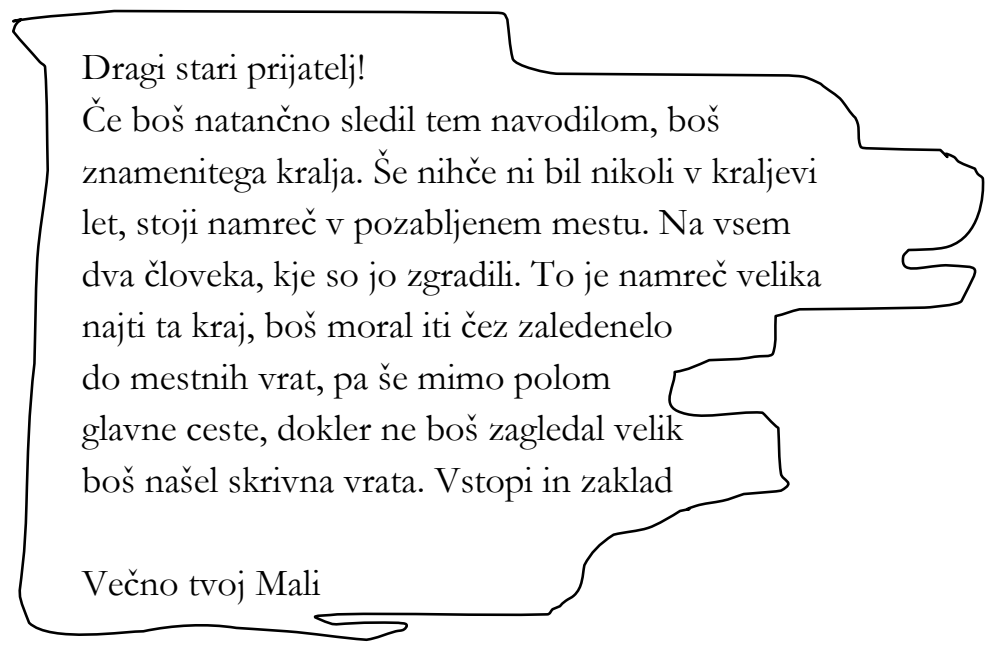

Slika 1: Skrivnostno pismo

Povedala sem jim, da sem v skrivnem predalu pisalne mize svoje babice našla tole pismo, ki pa je žal strgano in ga bo potrebno dopolniti. Dogovorili smo se, da bodo pismo poskušali čim bolj natančno dopolniti, saj nas očitno vodi do skritega zaklada. Najprej so dorisali še drugo stran pisma, nato smo se domenili, da morajo biti vse vrstice enako dolge. $\mathrm{Na}$ ta način sem se izognila temu, da bi učenci zapisali samo po eno ali dve besedi.

Učenci so se takoj lotili branja in pri delu v skupini so zelo sodelovali. Medtem sem na tablo projicirala dele pisma $v$ razmetanem vrstnem redu.

Učenci iz vseh skupin so po pretečenem domenjenem času želeli prebrati, kako so popravili oziroma dopisali manjkajoče podatke. Ugotovili so, da gre za opis poti in nekateri so pot tudi narisali.

Učence sem prosila, naj si ogledajo pismo in povedo, kaj je posebnega v njegovi zgradbi. Takoj so izpostavili podpis, nagovor, jedro (vsebinski del). Pozornost sem jim usmerila na projicirane dele in jim naročila, naj označijo dele pisma in dopišejo tudi tiste dele, ki jih morda niso zapisali (npr. datum). Z datumom so se nato kar poigrali, glede na to, da naj bi bilo pismo od bogvekdaj. 
Vprašala sem jih, če je pismo tako zanimivo, da bi o njem komu pisali. Skupaj smo razmišljali, da bi bilo dobro, da bi imeli ob sebi iznajdljivo osebo, ki bi nam pomagala priti do tega zaklada. Pobrskali smo za filmskimi junaki, ki vedno vse premagajo (Jackie Chan, Spiderman ...). Vsaka skupina se je nato sama odločila, komu bo pisala. Paziti so morali, da niso izpustili nobenega dela pisma, da so najprej osebo pozdravili in napisali kratek uvod, da so poročali o vsebini pisma, za zaključek predlagali, da bi se avanture lotili skupaj, se poslovili in da niso pozabili na podpis ter datum.

Učenci so bili navdušeni, nekateri so predlagali, da bi pisma res poslali, čeprav sem jim povedala, da je pismo izmišljeno in da ni nikjer nikakršnega zaklada.

Za domače delo so vadili pisanje pisma po naslednjih navodilih:

1. Najprej povej, da si se preselil in zato nisi imel časa za pisanje. (2 povedi ali več)

2. Povej, da imaš skrivnost in da jo moraš nekomu zaupati. (vsaj 2 povedi)

3. Razloži, da je nekaj narobe $z$ novo hišo in da te je strah. (5-10 povedi)

4. Prosi za pomoč ali nasvet. (3 povedi)

5. Izberi osebo, ki ji boš to pismo pisal.

6. Ne pozabi preveriti, če si napisal vse dele pisma.

Prav veselo je bilo pogledati učence, ko so odhajali iz razreda in drug drugemu razlagali, kako se bo njihova hiša ves čas nagibala $\mathrm{v}$ levo in desno, kako bo vhod na strehi in podobno.

Ko so učenci naslednjo uro prišli k uri slovenščine, so domačo nalogo imeli prav vsi. Vsak je hotel prebrati, kaj vse je bilo narobe z njegovo novo hišo. Ideje so se raztezale od običajnih duhcev, ki so jih strašili, do vesoljčkov in nenavadnih pojavov, ki so jim grenili življenje podnevi in ponoči. Vprašali so me tudi, če imam pripravljeno še kakšno na pol napisano pismo. Res sem ga imela, ampak to je že druga zgodba. (Priloga spodaj.) 


\section{Sklep}

Ob vseh neumetnostnih besedilih je potrebno imeti veliko idej, da učence pripraviš, da pri uri radi sodelujejo. Delovni zvezki in učbeniki vsebujejo dovolj kvalitetnih vaj, ki pa učencem ne predstavljajo velikega izziva. Rešujejo jih zato, da so rešeni, niso pa ob njih zares zbrani in ob njih premalo razmišljajo. Zato je nujno, da učitelj sam pripravlja ustvarjalne naloge, ki pritegnejo tudi današnjo mladež, ki predvsem ne mara pisati in ne zdrži zbrano pri besedilu prav dolgo. $Z$ vajami, pri katerih morajo učenci ob obravnavi učnih vsebin, ki so zapisane v učnem načrtu (prim. Ǔ̌ni načrt 2018), razmišljati tudi o vsebinskih rešitvah problema, jih vsaj delno lahko motiviramo za bolj vneto delo pri pouku.

\section{Literatura}

Ǔ̌ni nắrt. Slovenščina. Posodobljena iæ̨daja. 2018. Dostop 28. 9. 2019 na https://www.gov.si/assets/ministrstva/MIZS/Dokumenti/Osnovna-sola/Ucninacrti/obvezni/UN_slovenscina.pdf 


\section{Priloga}

Draga Sonja,

hvala za tvoje zadnje pismo. Zelo prijetno je bilo prebrati vse novice in krasno je, da si nas povabila k sebi v Kranjsko Goro za počitnice. Žal je to neuresničljiv projekt zaradi mnogih razlogov.

Najprej,

Druga pomembna stvar je

Pa še

Tako, vidiš, je čisto nemogoče, da bi bili cel teden odsotni od doma, pa tudi prav dobra družba za počitnice ta trenutek nismo. Upam, da razumeš, in upam, da se bomo videli vsaj za majske počitnice.

Prisrčen pozdrav 
Karmen Teresko

Nogavičeva 9

Ljubljana

Urad za izgubljene predmete

Masarikova 345

Ljubljana

Spoštovani!

Včeraj sem se peljala na progi Maribor-Ljubljana in

Želela bi izvedeti, ali

Za vse informacije se lepo

Lep pozdrav

Karmen Teresko 


\title{
Oglaševanje nekoč in danes - obravnava besedilne vrste
}

\author{
TJAŠA MARKEŽIČ
}

Povzetek V prispevku prikazujemo obravnavo besedila ekonomske propagande pri pouku slovenščine $\mathrm{v}$ prvem letniku gimnazijskega programa. V eni šolski uri smo kot zanimivost predstavili zgodovino oglaševanja, nato pa se osredotočili na značilnosti sodobnih reklamnih besedil. Dijaki so ob tem spoznali lastnosti ene od besedilnih vrst in usvajali temeljne jezikovne pojme. $\mathrm{V}$ nadaljevanju ure pa smo si ogledali »televizijske« oglase, ki so jih dijaki pred načrtovano učno uro posneli, in jih analizirali na osnovi novo pridobljenega znanja. Pri tem smo bili osredotočeni na: a) razvijanje pravopisne, pravorečne in poimenovalne zmožnosti ter b) sprejemanje in tvorjenje pisnih in ustnih besedil. Ob zaključku ure sem omenila tudi raziskovalno nalogo s področja Slovenski jezik, ki je proučevala jezikovne značilnosti oglasov, namenjenih prav dijakom Prve gimnazije Maribor.

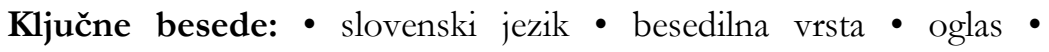
raziskovalna dejavnost $\bullet$ gimnazija $\bullet$

NASLOV AVTORICE: Tjaša Markežič, Prva gimnazija Maribor, Maribor, Slovenija, e-pošta: tjasa.markezic@prva-gimnazija.org. 


\section{Besedilo ekonomske propagande - teoretična izhodišča}

Za obravnavo teme je pomembno poznavanje pojmov oglas/reklama/propagandno besedilo in oglaševanje/reklamiranje. Tomo Korošec (2005: 16) za tovrstno besedilo dosledno uporablja termin oglas, ki ga definira kot od oglaševalca naročeno in snovalcu plačano jezikovno ali nejezikovno sporočilo oziroma njuno kombinacijo, ki informira o oglaševanem predmetu, storitvi ter s prvinami perlokucijske moči (to je z ustvarjanjem vedenja, spodbude, prepričanja, delanjem reklame, svarila, opozorila ...) posreduje bodisi v procesih menjave med ponudniki in porabniki blaga ali storitev bodisi $\mathrm{v}$ procesih širjenja idej od njihovih nosilcev $\mathrm{v}$ javnost. Iz te definicije lahko razberemo, da je oglasno sporočilo posredovano z jezikovnimi in nejezikovnimi oziroma pribesedilnimi sredstvi.

O oglaševanju pa govorimo kot o plačani obliki tržnega komuniciranja, pri kateri gre za prenos sporočila od naročnika prek medija do potrošnika. Oglaševanje ima pomembno vlogo pri uvajanju novih izdelkov in storitev ter hkrati ohranja zavest kupcev o določenem izdelku. V preteklosti so bili oglaševalci zadovoljni, če so si potrošniki njihov oglas zapomnili, danes pa je pomembno tudi, ali je oglas prepričal k nakupu v oglasu ponujenih dobrin ali storitev (Stramljič Breznik idr. 2008: 12). Po Korošcu (2004: 199) je oglaševanje ena od prvin publicistične dejavnosti; njena najizrazitejša pojavna oblika pa so oglasi. Izrazitost je dana s sorazmerno veliko pogostnostjo nastopanja bodisi različnih bodisi s ponovljivostjo istih oglasov ter $\mathrm{z}$ njihovo inherentno težnjo po vpadljivosti in opaznosti. Oglaševanje lahko razumemo kot sporočanjski oz. komunikacijski pojav, ki stopa pred javnost prek svojih raznovrstnih sporočil, sicer pa je sestavina širšega gospodarskega delovanja, ki se ukvarja s procesi menjave dobrin (Korošec 2005: 12).

\section{Besedilo ekonomske propagande v srednješolskih učbenikih}

Po učnem načrtu za gimnazije (Poznanovič 2008: 11-12) dijaki sprejemajo in tvorijo besedilo ekonomske propagande kot vrsto neumetnostnega besedila. Pregledali smo tri učbenike za slovenščino v 1. letniku gimnazij in srednjih strokovnih šol: Na pragu besedila 1, Slovenšcina 1: z. besedo do besede in Govorica jezilka 1. 
Učbenik Na pragu besedila 1 (Križaj Ortar idr. 2018: 90-93) za tovrstno besedilo uporablja poimenovanje propagandno ali oglaševalno besedilo, pri čemer loči besedila ekonomske propagande, kadar želi tvorec povečati svojo prodajo in zaslužek, in besedila politične propagande, če želi sporočevalec širiti svoje mnenje in $\mathrm{s}$ tem usmerjati mišljenje ter delovanje posameznika. Besedila so uvrščena med pozivna besedila. V 1. letniku dijaki spoznajo besedilo ekonomske propagande, ki ga sporočevalec tvori, kadar želi naslovnika prepričati, da je predstavljeni izdelek/kraj ... zanj najboljši/najustreznejši. Reklamno besedilo avtorice učbenika definirajo kot propagandno besedilo, s katerim skuša sporočevalec pridobiti naslovnika za nakup izdelka/obisk kraja $\ldots z$ enostavno hvalo in pretiravanjem pri predstavitvi. Za tovrstna besedila je značilno premišljeno nagovarjanje določene skupine ljudi, pri čemer so uporabljene razne strategije: pritegnitev znanih oseb, strokovnjakov; čezmerna hvala; uporaba besednih prvin, ki pritegujejo naslovnikovo pozornost in zbujajo prijetna čustva; kratko, duhovito, privlačno besedilo; besedilo se po navadi začne in konča s kratko povedjo, ki je vsebinsko in jezikovno nenavadna, pogosto pa tudi likovno poudarjena (geslo, npr. Od znanja jih razganja); zapisana oziroma vidna reklamna besedila navadno vsebujejo tudi sliko, fotografijo, ki dopolnjuje besedilo. Hkrati avtorice opozarjajo, da je prijeme oglaševalcev treba sprejemati zelo kritično. Nekateri namreč želijo prepričati ljudi, da kupijo ponujene izdelke, čeprav jih morda sploh ne potrebujejo. Pomembno je tudi, da morajo biti reklame v naši državi tvorjene v slovenskem jeziku. Ob zaključku poglavja avtorice poudarjajo, da je tvorjenje reklam družbeno odgovorno dejanje, zato ga urejajo posebne zakonske določbe. Tako velja, da je prepovedano oglaševanje tobačnih izdelkov, omejeno pa oglaševanje alkoholnih pijač; od zdravil se lahko oglašujejo le tista, ki se izdajajo brez recepta; ni dovoljena negativna ocena podobnega izdelka drugega proizvajalca; reklame ne smejo vsebovati prvin, ki bi lahko povzročile telesno ali duševno škodo ali bi nasprotovale enakopravnosti med spoloma.

Učbenik Slovenščna 1: ₹ besedo do besede (Vogel idr. 2016: 190-191) dosledno uporablja termina oglas in oglaševanje. Avtorice pa izpostavijo naslednje značilnosti oglasov: oglas trditve le postavlja, ne navaja pa argumentov zanje; oglasna besedila so pisana subjektivno; enako pomembna kot besedni del sta v oglasih tudi vidni ali zvočni del. Naročnik oglasa, ki je vedno znan, želi doseči, da bi naslovnik predstavljeni izdelek ali storitev kupil oz. se nanj/-o naročil. Tudi ta učbenik navaja posamezna sredstva za doseganje oglaševalčevega namena (npr. ponavljanje, navezovanje na modne smernice, sklicevanje na mnenje znanih oseb, posebne ugodnosti, demonstracija prej in potem, asociacije ...), ob tem pa izpostavi tudi nekaj zanimivosti, povezanih z 
zgodovino oglaševanja: iz katerega obdobja izvirajo prvi oglasi, kakšni so bili oglaševalci v srednjem veku in kako so javno razglašali svoja sporočila, kako je iznajdba litografije vplivala na razvoj oglaševanja, kako je družbenopolitično dogajanje v 18. stoletju povzročilo nastajanje potrošniške družbe in s tem želje po oglaševanju, kdaj se je oglaševanje še posebej razvilo, kdaj je bila ustanovljena prva oglaševalska agencija, kako množična so tovrstna sporočila $v$ Združenih državah Amerike ipd.

Učbenik Govorica jezika 1 (Zajc Berzelak idr. 2017: 84-85) pa izpostavlja vse razsežnosti pojavljanja oglaševalnih besedil v vsakdanjem življenju: spremljajo nas namreč na radiu in televiziji, kot oglasi v revijah in časopisih, na spletnih straneh ali mobilnih telefonih, nastopajo kot samostojni letaki, plakati, zloženke, videoprojekcije, kratki filmi. Njihova naloga je različna: nekatera predstavljajo, druga nas vzgajajo ali obveščajo, tretja ponujajo izdelke ali storitve. Oglaševalna besedila so rezultat natančne raziskave, ki mora odgovoriti na mnogo vprašanj: kdo je ciljna skupina, ki ji je besedilo namenjeno; kateri medij je najprimernejši za oglaševanje; kako oblikovati sporočilo ter kako pogosto ga posredovati javnosti. Kot bistveno značilnost tovrstnih besedil pa učbenik izpostavlja slogan - kratko in jedrnato sporočilo, ki povzema, dopolnjuje ali zaključuje besedilo, zaradi večjega učinka pa mora biti zapomnljiv, privlačen in izviren. Avtorice ugotavljajo, da nas najpogosteje nagovarjajo prodajni oglasi, ki jih imenujejo reklame in jih razlagajo kot javna besedila, ki nas želijo prepričati, da oglaševani izdelek ali storitev res potrebujemo. Tudi ta učbenik poudarja, da so oglaševalna besedila znana po svoji agresivnosti, ki jo lahko dosežejo s samo vsebino ali pojavnostjo, s pogostostjo in načinom oglaševanja, vendar tudi zanje veljajo nekatere omejitve, ki jih določa Slovenski oglaševalski kodeks.

\section{Primer obravnave pri pouku}

Znotraj učnega sklopa Obravnava besedilnih vrst sem se v 1. letniku programa splošna gimnazija lotila učne enote Besedilo ekonomske propagande. Sledili smo naslednjim funkcionalnim in izobraževalnim ciljem: dijaki razvijajo zmožnost logičnega mišljenja ter pravopisno, pravorečno in poimenovalno zmožnost; dijaki razvijajo svojo pragmatično, pomensko, slovarsko in slovnično zmožnost; dijaki sprejemajo in tvorijo pisna in ustna besedila; dijaki v besedilu poiščejo zahtevane informacije; dijaki ob obravnavi besedil vodeno povzamejo tipične lastnosti besedilnih vrst; dijaki pridobivajo temeljne jezikovne pojme: besedilo ekonomske 
propagande. Ob frontalni obliki izvajanja učne ure sem vključila tudi skupinsko in individualno delo, ob učnih metodah razlage, pogovora, prikazovanja in dela $\mathrm{z}$ besedilom.

Dijakom sem v uvodu učne ure na drsnicah prikazala dva časopisna oglasa za čevlje iste blagovne znamke, le da je eden iz leta 1928, drugi pa sodoben. Prosila sem jih, da razmislijo, $v$ čem sta si oglasa podobna in kako se razlikujeta. $S$ čim poskušata pritegniti naslovnikovo pozornost? Ugotovili smo, da je v starejšem oglasu mnogo več besedila (s cenami posameznih izdelkov ter s sloganom Cevlji, ki prinašajo uspeh) kot $\mathrm{v}$ sodobnem, kjer je poudarek na logotipu blagovne znamke in fotografiji izdelka, besedila pa sploh ni. Dijakom sem napovedala, da se bomo v tej uri pogovarjali o značilnostih besedil ekonomske propagande. Razdelila sem učne liste (priloga), na katerih so dijaki sproti dopolnjevali zapis snovi.

V jedru učne ure sem dijakom najprej predstavila oglaševanje skozi zgodovino (prve oglase, prve oglaševalce, prve časopisne oglase), nato smo si ogledali prvi slovenski oglas iz 18. stoletja. Sledi ogled oglasov z začetka 20. stoletja. Komentirali smo značilnosti, jezik, slog, nebesedne prvine. Opazili smo veliko jezikovnih napak (npr. Kmetovalci gnojite z Kalijevo soljo; Bolani na pljučah). Dijaki so poslušali razlago in dopolnjevali zapis na učnih listih; po potrebi so sodelovali v razgovoru. Nato smo se pogovorili o sodobnem oglaševanju. Povedala sem, da so oglasi definirani kot objave, obvestila z reklamnim, propagandnim namenom. Njihov namen je prepričati naslovnika. Do naslovnika dostopajo na različne načine - preko spleta, TV, radia, časopisov, revij, letakov ... Poleg različnih izdelkov lahko oglašujejo kraj, storitev, idejo.

V nadaljevanju sem predstavila značilnosti oglasov in izpostavila sredstva, s katerimi oglaševalci skušajo prepričati naslovnika. Dijake sem nato opozorila na pravila Slovenskega oglaševalskega kodeksa - v oglaševanju namreč marsikaj ni dovoljeno, denimo: opisi, trditve in primerjave morajo biti dokazljivi; oglasi ne smejo omalovaževati zgodovinskih in kulturnih spomenikov, dogodkov in državnih simbolov; oglaševanje mora spoštovati pravico do zasebnosti; prikazovati ali omenjati ne smejo nikogar, ki v to ni privolil; oglasi ne smejo uporabljati motivov kajenja, nasilja nad ljudmi, živalmi in rastlinami, pijančevanja, kraje, uživanja mamil, nesocialnega vedenja na način, ki te pojave spodbuja oziroma posredno ali neposredno odobrava; v oglasih ni dovoljeno nepošteno ali neobjektivno napadati ali razvrednotiti drugih izdelkov oziroma blagovnih znamk, oglaševalcev ali njihovih 
sporočil; oglasi za alkoholne pijače se ne smejo objavljati na radiu, televiziji ali v kinematografih med programom, takoj pred njim ali takoj za njim, če ga poslušajo in gledajo zlasti mladostniki; kršitelja pravil lahko prijavimo na Oglaševalsko razsodišče.

Prikazala sem nekaj posebnosti oz. zanimivosti iz sodobnih oglasov, povzetih po priročniku Tako je bolje (Stramljič Breznik idr. 2008) - zlasti smo bili pozorni na jezikovne napake in druge nesmiselnosti, npr. stegno svinsko, zreski; dobro zame - zemlja za grob; bio paśteta iz shita ipd. -, nato pa sem dijake spomnila na njihovo dosedanje delo: nekateri od njih so po skupinah pripravili oglasna besedila, $v$ glavnem videoposnetke. Prosila sem jih, da so svoje delo predstavili sošolcem. Posnetke smo si ogledali in jih analizirali: razmišljali smo, ali gre za oglaševanje predmetov ali storitev, opazovali značilnosti oglasnih besedil (morebitne slogane, vključena mnenja znanih oseb, posebne ponudbe ipd.).

V zaključku učne ure sem dijakom prikazala oglase (zadnja naloga na učnem listu) in jih prosila, da jim določijo sporočevalca, naslovnika, namen, nebesedne spremljevalce; izbrala sem oglasna besedila, ki so bila na voljo na oglasnih mestih na naši šoli, tako da so bila dijakom znana in za njih zanimiva, saj so oglaševala inštrukcije, krožke, zabave ... Komentirali so tudi jezik in slog. Ob zaključku sem omenila raziskovalno nalogo s področja Slovenski jezik, ki je proučevala prav oglase, namenjene dijakom Prve gimnazije Maribor.

\section{Jezikovna podoba oglasov v luči raziskovalne naloge}

Tomaž Golub (2012), dijak 3. letnika klasične gimnazije v šolskem letu 2011/12, je pripravil raziskovalno nalogo $\mathrm{z}$ naslovom Instruiram matematiko in te vabim na halloween party: kaj labko dijaki pričakujemo $v$ oglasih, $\mathrm{v}$ kateri je zbral in analiziral 46 oglasov, ki so bili na šolskih oglasnih mestih na voljo dijakom Prve gimnazije Maribor: 28 je bilo trosilnih, 18 pa malih plakatnih. Največ zbranih storitvenih oglasov je oglaševalo zabavo, ki vključuje gostinske storitve (37\%), sledili so oglasi, ki ponujajo aktivno preživljanje prostega časa (26\%), in oglasi s ponudbo dodatnega izobraževanja (22 $\%)$. Najmanj oglasov je nudilo zavarovalniške storitve (15\%). Vsi oglasi so bili zbrani na srednji šoli in so tako, kot so bili dostopni Tomažu, vsakodnevno dosegljivi vsem dijakom, ki se sprehodijo po glavnem stopnišču šole. Prav zato, ker dijake kot javno objavljena besedila spremljajo v šoli, moramo razmisliti o njihovi jezikovni podobi. Kljub temu da gre za manjši vzorec, zbran v kratkem časovnem obdobju (dva 
meseca), je dijak lahko izpeljal določene sklepe. Večina hipotez, ki si jih je zastavil ob začetku pripravljanja naloge, je bila potrjenih: glede na tipologijo Toma Korošca so prevladovali pridobitni oglasi; oglaševalci so dijakom v glavnem ponujali dodatne možnosti izobraževanja in zabavo; sporočevalci so dijakom nudili posebne ugodnosti, tako imenovane izredne ponudbe, ki so časovno ali kako drugače omejene; v oglasih so upoštevana pravila Slovenskega oglaševalskega kodeksa; pri zbranih oglasih se je pojavljalo odstopanje od pravopisnih pravil; oglasi, povezani z zabavo in prostim časom, so vsebovali največ prevzetih besed; pogosti so bili pridevniki vroč, senzacionalen, ustvarjalen, zabaven, strokoven, ki skušajo privabiti $\mathrm{k}$ uporabi storitve, pridevniki bresplačen, ugoden, cenejši, najnið̌ði pa poudarjajo ugodnost. Oglasi so vsebovali tudi ponavljanja ključnih besed ali imena izdelka/storitve. Naloga nakazuje, da so oglasi, ki so namenjeni mladini, oblikovani tako, da privlačijo zlasti s prevzetimi besedami (npr. highschool party, trendy Fridays), ki imajo pogosto prednost pred domačimi ustreznicami. Pojavljajo se tudi ponavljanja določenih besed (smo proti iそkorišcanju, proti zadoľ̌evanju, proti nepravi demokraciji ...), s čimer ustvarjalci želijo doseči, da bi naslovnik postal pozoren na bistvene elemente in si jih zapomnil. Oglaševalci naslovnika - dijake brez izjeme tikajo, s čimer jih prijateljsko nagovarjajo in se jim tako približajo (npr. Ker boš 24 ur na dan nezgodno zavarovan). Pogosto zato, da bi dijake prepričali o uporabi storitev - kajti najpogosteje jim nudijo storitve oglaševalci ponujajo dodatne ugodnosti, kot so welcome drink, nagrade ... Poleg pogostega nepotrebnega prevzemanja besed (tu je mišljena zlasti raba citatnih besed) se zdi skrb vzbujajoče še dvoje: pogosto odstopanje od pravopisne norme (izpust ločil, napačno sklanjanje, pravopisne napake ...) in dejstvo, da Tomaž v dveh mesecih ni zasledil nobenega vzgojnega oglasa. Oglaševalci torej mladini v glavnem ponujajo najrazličnejše storitve, med katerimi ima zabava prednost pred dodatnim izobraževanjem, kar kaže večji odstotek oglasov s ponudbo gostinskih storitev. Raziskovalna naloga tako želi opozoriti, da oglasi za dijake ne morejo predstavljati zgled pravilne jezikovne rabe.

\section{Sklep}

Oglaševanje je $\mathrm{v}$ današnjem času neizbežen pojav; spremlja nas vsak dan, na vsakem koraku. Ponudniki blaga in storitev se na različne načine trudijo pritegniti našo pozornost; to počnejo s pomočjo različnih medijev (radia, televizije, spleta, revij in časopisov, letakov, plakatov ...) ter $\mathrm{z}$ različnimi jezikovnimi in nejezikovnimi sredstvi. Naštete medijske poti pa niso edini način dostopanja do naslovnika; oglaševanje vstopa tudi v srednjo šolo in o nakupu izdelka ali uporabi storitve skuša 
prepričati dijake. Raziskovalna naloga s področja slovenskega jezika dokazuje, da je oglaševalčev namen, ustvariti zanimivo, atraktivno in drugačno oglaševalno besedilo ter prepričati dijake o pravilni izbiri izdelkov ali storitev, dosežen tudi s pomočjo izbrane leksike.

\section{Viri in literatura}

Tomaž GOLUB, 2012: Inštruiram matematiko in te vabim na halloween party: kaj labko dijaki pričakujemo $v$ oglasih. Raziskovalna naloga. Maribor: Prva gimnazija Maribor.

Tomo KOROŠEC, 2004: K tipologiji oglaševalnih besedil. Aktualizacija jezikovnozvrstne teorije na Slovenskem: Clenitev jezikoune resničnosti. Ur. Erika Kržišnik. (Obdobja, 22). Ljubljana: Filozofska fakulteta.

- -, 2005: Jezike in stil oglaševanja. Ljubljana: Založba FDV.

Martina KRIŽAJ ORTAR idr., 2018: Na pragu besedila 1. Učbenik za slovenski jezik v 1. letniku gimnazij in srednjih strokovnih šol. Ljubljana: Rokus.

Mojca POZNANOVIČ, 2008: Uíni načrt. Slovenšcina: gimnazija: splošna, klasična, strokovna gimnazija. Ljubljana: Ministrstvo za šolstvo in šport.

Irena STRAMLJIČ BREZNIK, Melita ZEMLJAK JONTES, Simona PULKO, Alenka VALH LOPERT, Mira KRAJNC IVIČ, 2008: Tako je bolje: priročnik z nasveti, kako odpraviti nekatere najpogostejš jezikovne težave v prodajnih katalogih trgovcev. Maribor: Filozofska fakulteta.

Jerca VOGEL idr., 2016: Slovenšcina 1: z besedo do besede. Učbenik za slovenščno - jezilk v 1. letniku gimnarij in srednjih strokovnih šol. Ljubljana: Mladinska knjiga.

Karla ZAJC BERZELAK idr., 2017: Govorica jezilka 1. Slovenšcina za 1. letnik gimnazij. Ljubljana: Rokus. 
Priloga - učni list za obravnavo pri pouku

\section{BESEDILO EKONOMSKE PROPAGANDE \\ (oglas, reklama)}

\section{ZGODOVINA OGLAŠEVANJA}

- STARI VEK: prvi oglasi 2000 pr. Kr. v

- _ oglaševanje po ulicah in trgih.

- NOVI VEK: razmah oglaševanja po izumu

- 18. STOLETJE: prvi oglasi (tudi na Slovenskem).

\section{OGLAŠEVANJE DANES}

- OGLAS: objava, obvestilo z reklamnim, namenom.

- NAMEN: prepričati

- OBLIKA: časopis, revija, splet, TV, radio, letaki ...

- VSEBINA: izdelek, kraj, storitev, dogodek ...

\section{ZNAČILNOSTI OGLASOV}

- nagovarjanje določene skupine ljudi;

- uporaba raznih strategij;

- čezmerna

- uporaba besednih prvin, ki pritegujejo in zbujajo prijetna čustva;

- kratko, duhovito, privlačno besedilo;

- vsebinsko in jezikovno nenavadna poved, pogosto tudi likovno poudarjena

- slika, fotografija pri zapisanih oglasih. 


\section{KAKO PREPRIČATI NASLOVNIKA?}

- ponavljanje;

- navezovanje na modne smernice;

- sklicevanje na mnenje

- kakovost izdelkov potrjujejo

- posebne ugodnosti, t. i. izredne ponudbe, ki so časovno omejene;

- demonstracija prej-potem;

\section{SINTEZA}

\section{Izbranim oglasom oglasom določi:}

- sporočevalca,

- naslovnika,

- vsebino in namen,

- nebesedne spremljevalce. 


učence in dijake voditi do znanja slovenščine, so inovativni, odraz velike zavzetosti učiteljic, ki želijo drugačne, za učence in dijake privlačne in uporabne načine poučevanja.

\section{Dr. Milena Ivanuš Grmek}

Monografija bralcu in

\section{bralki v dostopni obliki}

predstavlja najprej sodobne metode

izdelave učnih gradiv, nato pa mnoge ideje,

kako učencem in dijakom ustvarjalno približati

sicer morda zahtevne učne vsebine s poudarkom na

njihovi aktualnosti. Posebno kvaliteto daje monografij

zasnova, ki metodoloških postopkov ne predstavlja samozadostno, kot cilj sam po sebi, temveč dosledno v funkciji izdelave posameznih didaktično, torej strokovno utemeljenih segmentov e-učnega okolja. Prispevki nazorno prikažejo smiselnost avtomatizacije povsod, kjer je lahko najbolj v pomoč bodisi z dodatnim motiviranjem učečih se bodisi z razbremenjevanjem učiteljic in učiteljev tam, kjer bi bilo njihovo delo sicer najmanj ustvarjalno.

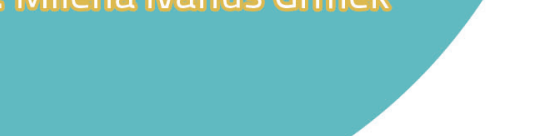

